\title{
A dSAGA specifikus hiszton acetiláció génmúködés szabályozásban betöltött funkciójának vizsgálata
}

Doktori értekezés

Készítette: Zsindely Nóra

Témavezető:

Dr. Boros Imre Miklós

Szegedi Tudományegyetem

Természettudományi és Informatikai Kar

Biokémiai és Molekuláris Biológiai Tanszék 


\section{Tartalomjegyzék}

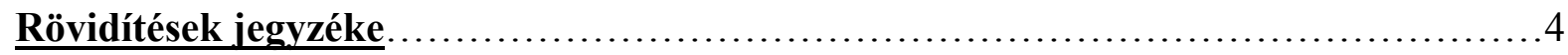

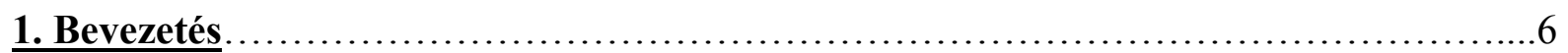

1.1 A kromatin szerveződése...................................................6

1.2 A nukleoszómák és a hiszton fehérjék szerkezete..................................................... 7

1.3 A hiszton fehérjék poszttranszlációs módosításainak a kromatin szerveződésére

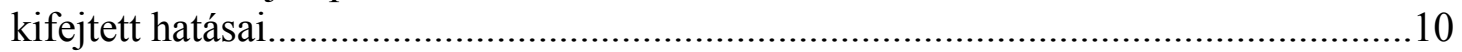

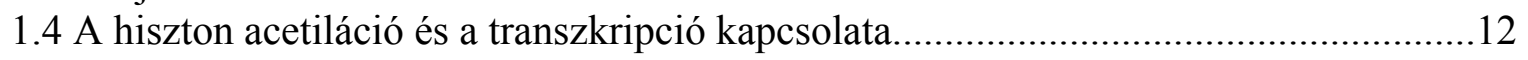

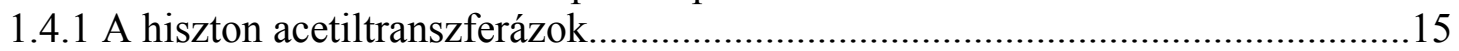

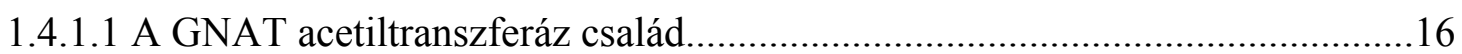

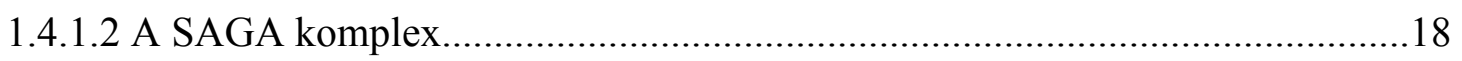

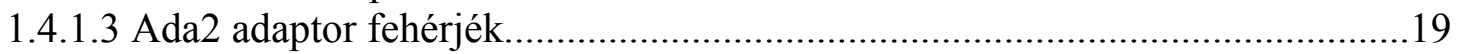

1.4.1.4. Drosophila Gen5-tartalmú HAT komplexek..................................................20

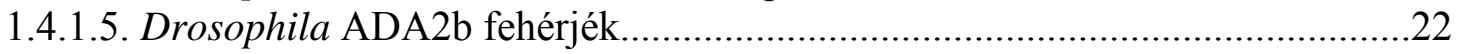

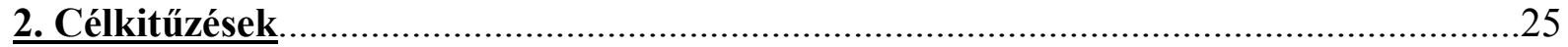

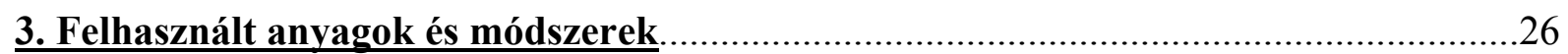

3.1 Felhasznált Drosophila melanogaster törzsek, keresztezések...............................26

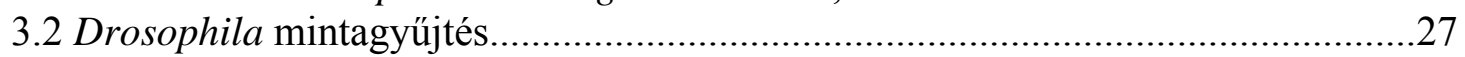

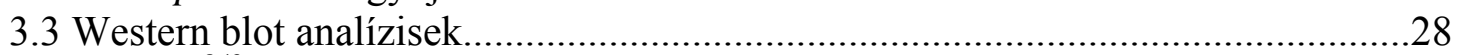

$3.4 d A d a 2 b^{842}$ mutáns Drosophila lárvák transzkriptom vizsgálata DNS microarray

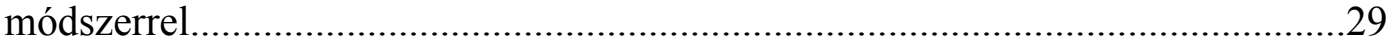

3.5 Nyálmirigy óriáskromoszóma preparálás és immunfestés..................................30

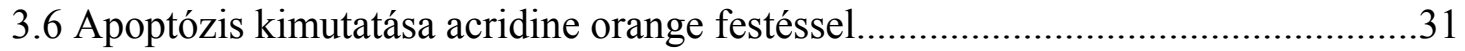

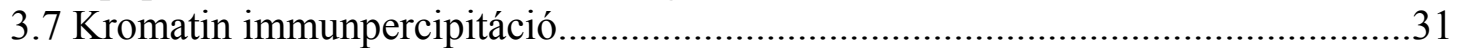

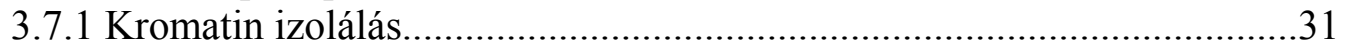

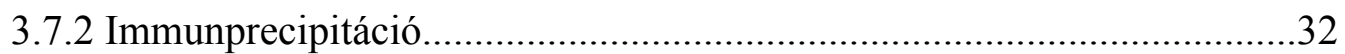

3.7.3 DNS-fehérje keresztkötések megszüntetése és DNS tisztítás...................33

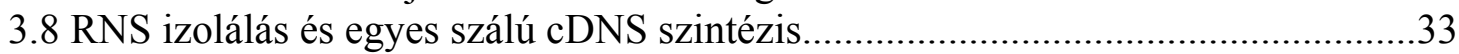

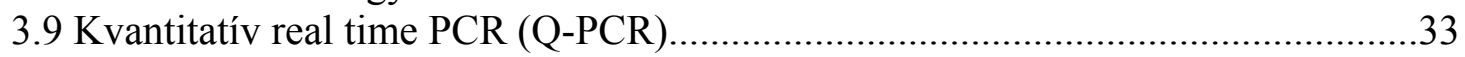

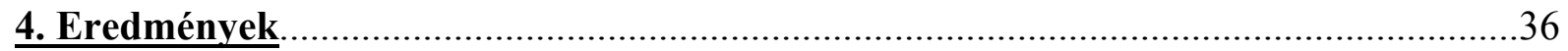

4.1 A dSAGA specifikus H3K9 és K14 acetiláció szabályozása alatt álló gének

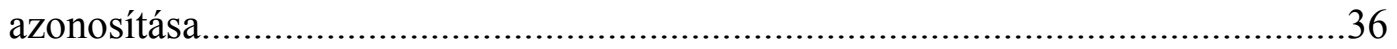

4.1.1 dAda2b mutánsok transzkriptum analízise késői L3 lárva és korai báb

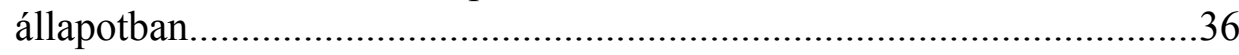

4.1.2 A dADA2b hiányában a vad típustól eltérő expressziót mutató gének

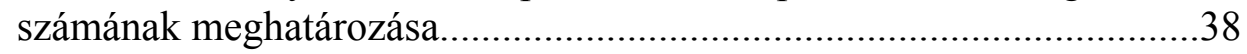

4.1.3 dADA2b-függő expressziót mutató gének funkcionális csoportosítása...39

4.2 A dSAGA komplexre specifikus dADA2b alegység két izoformájának a dSAGA müködésében betöltött funkciója..................................................................42

4.2.1 A dADA2b izoformák expressziójának vizsgálata................................42

4.2.2 A dADA2b rövid izoforma funkcionális vizsgálata................................44

4.2.2.1 A dADA2b izoformák vizsgálatához használt transzgenikus törzsek jellemzése.................................................................44

4.2.2.2 A dADA2bS hatása a dAda2b ${ }^{842}$ deléció letális fenotípusára.......45 
4.2.2.3 A dADA2bS izoforma szerepe a dSAGA specifikus H3K9 acetiláció létrehozásában.

4.2.2.4 A dADA2bS izoforma szerepe a Dmp53 által irányított apoptotikus folyamatok szabályozásában

4.2.3 A dADA2bS izoforma transzkripció szabályozásra kifejtett hatásának vizsgálata.

4.3 A dSAGA komplex által létrehozott H3K9 acetiláció a génexpresszió szabályozásában betöltött szerepének meghatározása.

4.3.1 A ChIP kísérletben vizsgált gének jellemzése.

4.3.2 A RNS polimeráz II mennyiségének meghatározása a módosult transzkripciót mutató gének területén

4.3.3 A dADA2b fehérje kötődésének meghatározása a dSAGA-függő, valamint a dSAGA-független gének területén.

4.3.4 A dSAGA specifikus H3K9 acetiláció szintje az eltérő irányú transzkripciós változást mutató dSAGA-függő gének területén.

4.4 A dSAGA specifikus H3K9 acetiláció génaktivációban betöltött szerepének vizsgálata.

4.4.1 A H3K9 acetiláció szintjének meghatározása az aktivált hősokk gének területén.

4.4.2 A génaktivációt kísérő H3K9 acetilációs mintázat meghatározása az Eip74EF és Eip75B ekdizon indukált korai géneken.

4.4.3 Az Eip74EF és Eip75B gének aktivációja során megjelenő H3K9 acetilációs mintázat létrehozásáért felelős HAT azonosítása.

4.4.4 A dSAGA specifikus H3K9 acetiláció szerepe az Eip74EF és Eip75B ekdizon indukált gének aktivációjában.

5. Eredmények megvitatása. .65

5.1 A dSAGA acetiltranszferáz komplex szabályozása alatt álló gének.

5.2 A dSAGA komplexre specifikus dADA2b alegység rövid izoformájának szerepe a dSAGA müködésében. .66

5.3 A dSAGA komplex és az általa létrehozott H3K9 acetiláció szerepe a génexpresszió szabályozásában.

5.4 A dSAGA specifikus H3K9 acetiláció szerepe a génaktiváció folyamatában.........70

5.5 A dSAGA specifikus hiszton acetiláció feltételezett funkciója a génmüködés szabályozásában. 


\section{Rövidítések jegyzéke}

ADA2: alternation/deficiency in activation-2

ADA3: alternation/deficiency in activation-3

AMP: $\underline{\text { AntiMikrobiális Peptid }}$

AttD: $\underline{\text { Attacin-D }}$

ChIP: kromatin immunprecipitáció

cnc: $\underline{\text { cap and }} \underline{\text { collar }}$

CycB: $\underline{\text { cyclin } \underline{B}}$

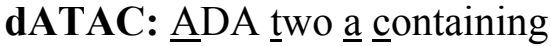

DUBm: deubiquitinációs modul

E(y)2: Enhancer of yellow 2 Drosophila

FCS: $\underline{\text { Foetal }} \underline{\text { Calf }} \underline{\text { Serum }}$

Fst: $\underline{\text { Frost }}$

Gcn5: general control nonderepressible $\underline{5}$

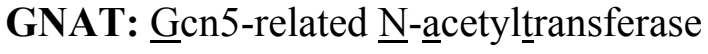

HAT: hiszton acetiltranszferáz

HDAC: hiszton deacetiláz

Hus: Hus 1-like

ISWI: imitation switch

MYST: $\underline{M} O Z, \underline{Y} b f 2 / S a s 3, \underline{S} a s 2$, Tip60

NAC: № Antibody Control

Nonstop: Drosophila analog of Ubp8

NuA4: nucleosome acetyltransferase of $\mathrm{H} \underline{4}$

p300/CBP: protein of $\underline{300} \mathrm{kDa}$ and $\underline{\mathrm{CREB}}-\underline{\text { binding protein }}$

PCAF: p300/CBP-associated factor

Rpd3: reduced potassium deficiency $\underline{3}$

RpL32: Ribosomal protein L $\underline{\text { 32 }}$

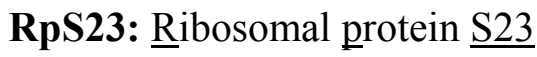

SAF6: SAGA factor-like TAF6

SAGA: $\underline{\text { Spt}}$ - $\underline{A} d a-\underline{G} c n 5-\underline{A} c e t y l t r a n s f e r a s e$

SANT: Swi3-Ada2-NCoR-TFIIIB

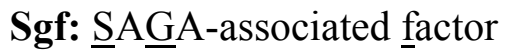


SpEv: Spiracle Everted

Spt: suppressor of Ty element

SRC: steroid receptor coactivator

sug: sugarbabe

Sus1: $\underline{\mathrm{S}} 1$ gene $\underline{u} p s t r e a m$ of $y \underline{S} a 1$

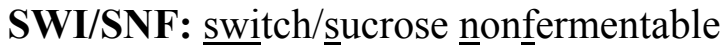

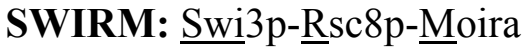

TAF: TATA box-binding protein-associated factor

TBP: $\underline{T A T A} \underline{B} i n d i n g \underline{\text { Protein }}$

TFIID: Transcription Factor $\underline{\text { II }} \underline{\mathrm{D}}$

TIC: Total Input $\underline{\text { Control }}$

Ubp8: ubiquitin-specific processing protease 8

Wda: will decrease acetylation

wL3: vándorló L3 lárvastádium 


\section{$\underline{\text { 1. Bevezetés }}$}

\section{$\underline{1.1 \text { A kromatin szerveződése }}$}

Nagymértékü, rendezett tömörítésre van szükség ahhoz, hogy az eukarióta sejtek méteres nagyságrendű DNS állománya beférjen a mikrométeres méretű sejtmagba. Ugyanakkor a genomot templátul használó vagy az azt módosító, a sejt működéséhez alapvető fontosságú folyamatok (transzkripció, replikáció, rekombináció és hibajavítás) hibátlan megvalósulásához ennek a tömörödésnek rendkívül szabályozottnak és dinamikusnak kell lennie. A genom nagymértékű, ugyanakkor dinamikus összetömörítését a különböző fehérje faktorok közremüködésével létrejövő kromatinszerkezet biztosítja. A tömörítés első lépéseként számos, erősen bázikus tulajdonságú hiszton fehérje kapcsolódik a DNS-hez, létrehozva ezzel a kromatinszerkezet ismétlődő alapegységét, a nukleoszómát [1]. A nukleoszómák négy, ún. „core” hiszton fehérje (H2A, H2B, H3 és H4 hiszton) által kialakított hiszton oktamerből, valamint az arra rátekeredő 147 bázispárnyi DNS-ből épülnek fel. Minden nukleoszómát egy 10-60 bázispár hosszúságú, összekötő (linker) DNS szakasz választ el egymástól. A tömörítésnek ez az első lépése egy $11 \mathrm{~nm}$ átméröjü kromatinszál kialakulását eredményezi, amelyet gyöngyfüzér struktúrának nevezünk [2]. A DNS-nek ez a csomagolása bizonyos faktorok számára, például a replikáció során a DNS polimeráz számára még hozzáférhetőséget biztosít, ugyanakkor már bizonyos védelmet is nyújt a DNS károsodásokkal szemben. A tömörödés következő lépésében a szomszédos nukleoszómák között kialakuló kapcsolatok révén a gyöngyfüzér struktúra spirálszerűen feltekeredik, és egy tömörebb, $30 \mathrm{~nm}$ átmérőjü kromatinszálból felépülő szerkezet alakul ki. Az interfázis során a genom nagy része ennél a 30 nm-es szálnál kompaktabb, 110-170 nm átmérőjü kromatinszálakba tömörül. A sejtosztódás során további tömörítési lépések mennek végbe, míg végül kialakulnak a metafázisra jellemző kromoszómák, amelyek mintegy 10000-szeres kompaktálódásnak felelnek meg [3] (1. ábra).

Általánosságban elmondható, hogy ez a tömör kromatin struktúra gátolja a DNS szálon lezajló folyamatok (DNS replikáció, DNS hibajavítás és transzkripció) jelentős részét, mivel ebben a formában a DNS szál nem hozzáférhető az ezeket a folyamatokat végző fehérje faktorok számára. Ezért a sejt normális müködéséhez a tömör kromatinszerkezet létrejöttének és felbomlásának rendkívül dinamikus folyamatnak kell lennie. Például az interfázis során 
rendkívül erősen expresszálódó gének területén az átírást végző RNS polimeráz kötődésének idejére akár a $10 \mathrm{~nm}$ átmérőjü, nyitott kromatin struktúra is kialakulhat, ugyanis a polimeráz DNS-hez kapcsolódása megakadályozza a kompaktabb szerkezet azonnali visszarendeződését. Ezzel szemben a sejtosztódás profázisában a genom egy része a nagyfokú tömörítés eredményeképpen már 200-250 nm átmérőjü kromatin szálak formájában jelenik meg [3]. Ez a dinamikusan átrendeződő kromatinszerkezet egyben egy fontos szabályozó szerepet is betölt a DNS replikáció, a DNS hibajavítás valamint a transzkripció folyamatának szabályozásában.

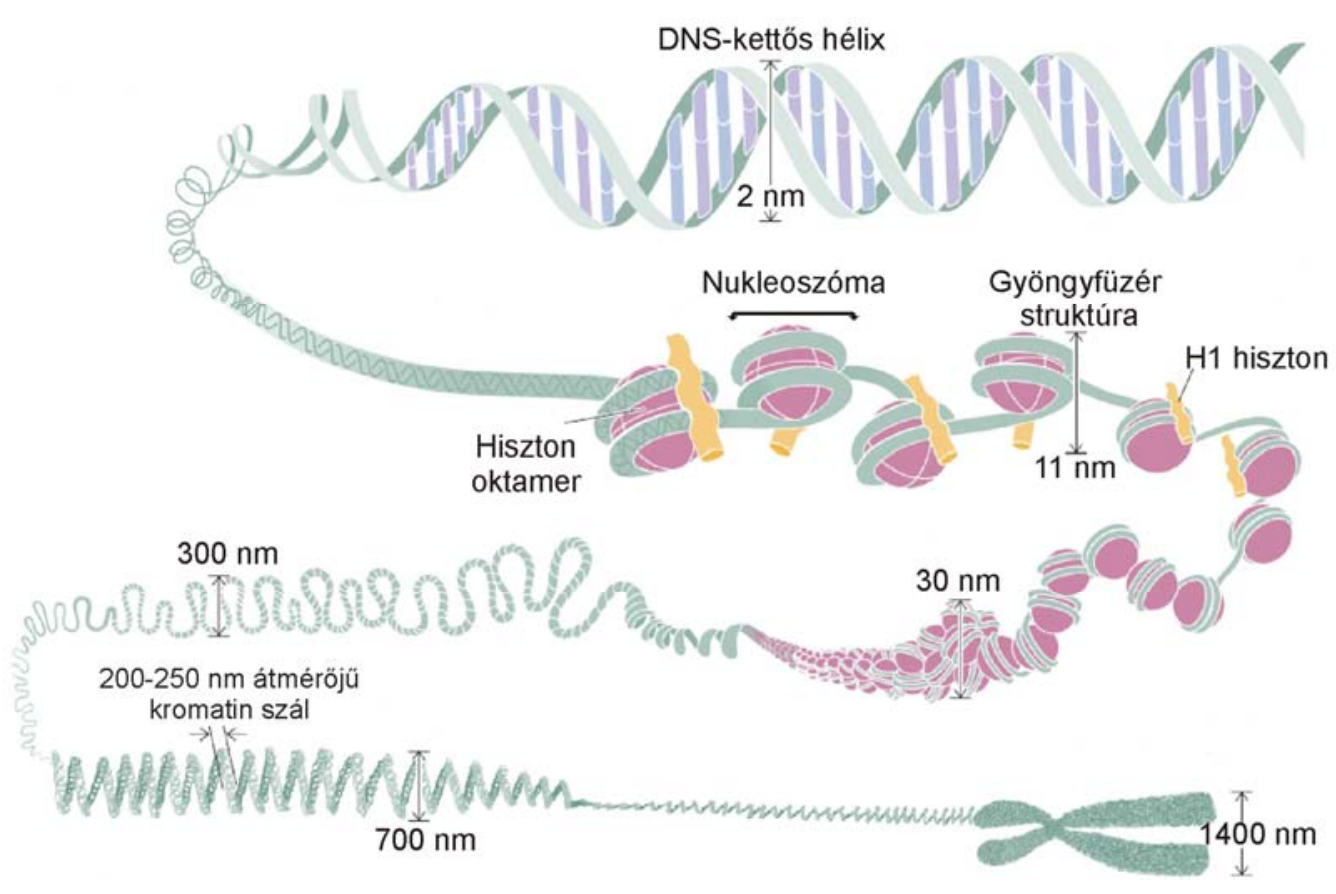

\section{1. ábra: A kromatin szerveződése}

A sematikus ábrán a kromatin szerveződésének különböző szintjei láthatóak. Az ábra a [4] forrás alapján készült.

\subsection{A nukleoszómák és a hiszton fehériék szerkezete}

A nukleoszómákban két H2A-H2B dimerből, valamint két-két H3-H4 fehérjéből összeálló (H3-H4) 2 tetramerből felépülő hiszton oktamer köré a 147 bp hosszúságú DNS 1 és 3/4 balmenetes szuperhelikális fordulattal tekeredik fel [5]. Az oktamert felépítő „core” hisztonok evolúciósan rendkívül konzervált szerkezetü fehérjék, több $\alpha$-helikális régióval rendelkeznek, amelyek két fontos szerkezeti elem, az ún. „histone fold” domén, valamint a „histone handshake” szerkezet kialakításában vesznek részt. Mind a négy „core” hiszton esetében a „histone fold” domén három - egy hosszabb és két rövidebb - $\alpha$-hélixből épül fel, 
amelyeket nem-helikális szerkezetü, ún. „loop” régiók választanak el egymástól (2. ábra). A H3-H4, illetve a H2A-H2B dimerek kialakításához a hasonló szerkezetü „histone fold” doménjeiken keresztül kapcsolódnak egymáshoz a H3 és H4, illetve a H2A és H2B fehérjék, és létrehozzák a hiszton fehérjéket összekapcsoló, ún. „histone handshake” szerkezetet (3. ábra). A „histone fold” domének felelősek a DNS kötéséért is, amely során a DNS kis árka hidrogén-híd vagy ionos kölcsönhatások révén kapcsolódik a hiszton oktamerhez. Ennek során a hisztonok $\alpha$-helikális és a köztes „loop” régiói alakítanak ki kapcsolatot a DNS foszfodiészter gerincével, így a hiszton oktamer minden DNS szekvenciához hasonló erősséggel képes kötődni [6].

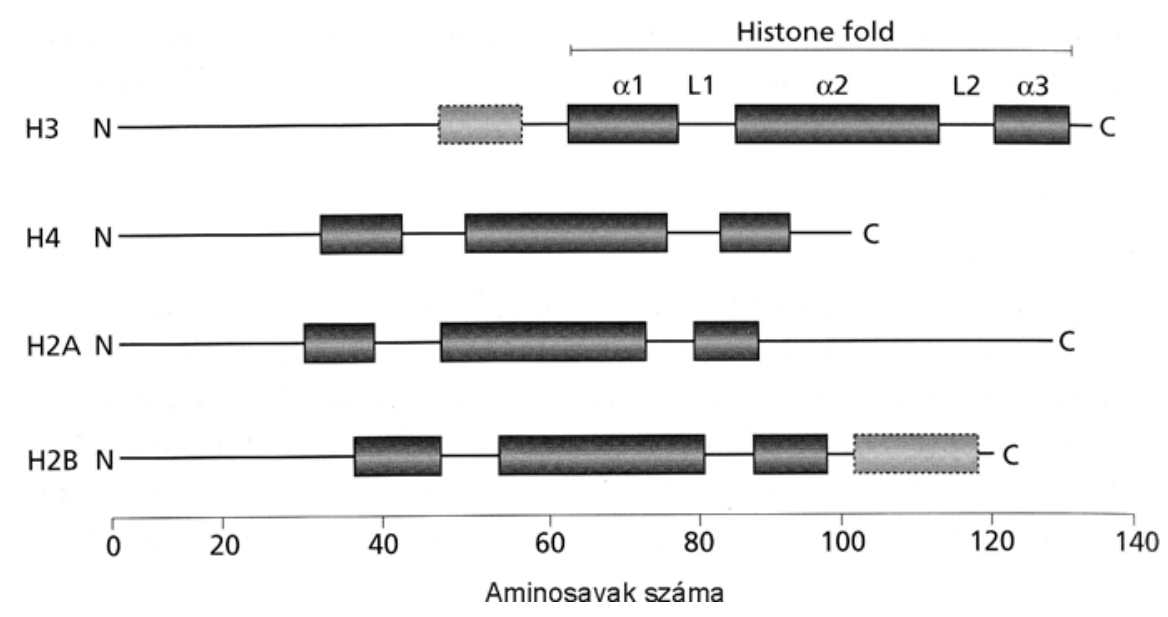

2. ábra: A „core” hiszton fehérjék doménszerkezetének sematikus rajza

A sötétszürke téglalapok a hiszton fehérjék közötti kapcsolatot kialakító „histone fold” régiót alkotó $\alpha$-hélixeket $(\alpha 1, \alpha 2, \alpha 3)$ jelölik. Az L1 és L2 rövidítések a hélixeket elválasztó, nemhelikális szerkezetü „loop” régiókat jelölik. A H3 és H2B fehérjénél látható világosszürke téglalapok azoknak az $\alpha$-helikális szerkezeteknek az elhelyezkedését mutatja, amelyek nem vesznek részt a „histone fold” domén kialakításában [7].

Mind a nyolc „,core” hiszton fehérje esetében kiemelkedik a nukleoszómák felszínéről egy 20-35 aminosav hosszúságú, bázikus aminosavakban gazdag N-terminális domén (ú.n. hiszton farok). A „histon fold” doménekhez hasonlóan ezek a régiók is evolúciósan erősen konzerváltak, viszont aminosav-összetételük alapján nem rendelkeznek tipikus másodlagos szerkezeti motívumokkal, általában ún. „random coil” szerkezetet vesznek fel. A H3 és H2B hisztonok N-terminális doménje a hiszton oktamerre kétszeresen feltekeredő DNS szál csavarulatai között, míg a H4 és H2A fehérjék N-terminális végei a nukleoszómális DNS kis árkai mentén, a „,core” partikulum tetején és alján emelkednek ki a nukleoszóma síkjából (4. ábra). Ezeken felül a H2A hiszton egy rövidebb (15 aminosavból álló), felxibilis C-terminális doménnel is rendelkezik, amely a nukleoszómális DNS be- és kilépési pontjánál hagyja el a nukleoszóma felszínét [6]. Ezek a nukleoszómák síkjából kiemelkedő hiszton terminális 
domének fontos szerepet töltenek be a szomszédos nukleoszómák között létrejövő kapcsolatok kialakításában, és ezáltal nagyban hozzájárulnak a tömörebb vagy lazább kromatinszerkezet kialakításához [8].

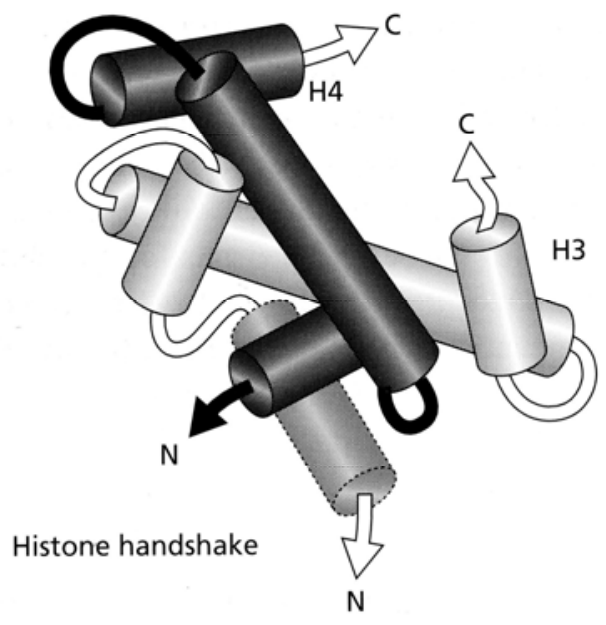

3. ábra: A H3 és a H4 hiszton fehérje összekapcsolódása során létrejövő „histone handshake" szerkezet

A szürke hengerek a H3 és a H4 hiszton fehérjék „histone fold” doménjeit felépítő $\alpha$-hélixeket jelölik [7].

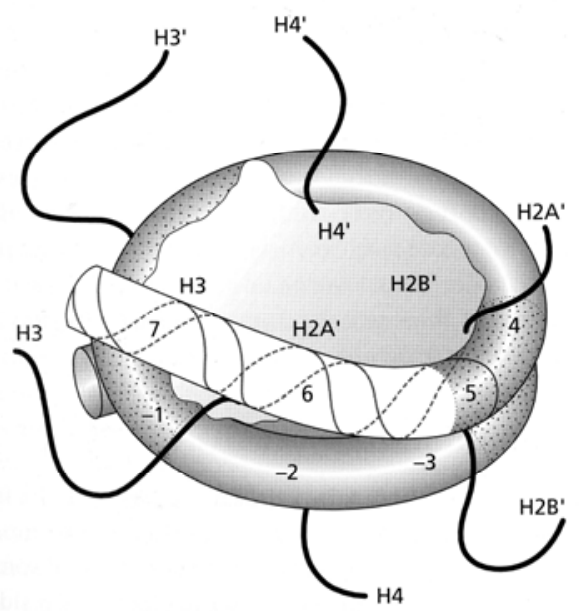

4. ábra: A nukleoszómákat alkotó hiszton fehérjék N-terminális doménjeinek elhelyezkedése a nukleoszómákban [7]

A hiszton fehérjéken rendkívül sokféle poszttranszlációs módosítás jelenhet meg (1. táblázat). Ezek a módosítások elsősorban a hisztonok N-terminális régióján történnek, de számos, a globuláris domén területén megjelenő módosítást is azonosítottak [2]. A H3, a H2A és a H2B hisztonok rövidebb, C-terminális doménjén eddig csak néhány poszttranszlációs módosítást azonosítottak, mint például a H2A 119-es, illetve a H2B 120-as lizinjén megjelenő ubiquitin módosítást [9]. 


\begin{tabular}{|c|c|c|c|}
\hline Módosítás & Aminosav & Hiszton & Példa \\
\hline acetiláció (ac) & lizin $(\mathrm{K})$ & $\mathrm{H} 2 \mathrm{~A}, \mathrm{H} 2 \mathrm{~B}, \mathrm{H} 3, \mathrm{H} 4$ & $\mathrm{H} 3 \mathrm{~K} 14 \mathrm{ac}$ \\
\hline \multirow[t]{2}{*}{ metiláció (me) } & $\operatorname{lizin}(\mathrm{K})$ & $\mathrm{H} 3, \mathrm{H} 4$ & H3K9me3 \\
\hline & $\operatorname{arginin}(' R)$ & $\mathrm{H} 3, \mathrm{H} 4$ & H3R17me \\
\hline \multirow[t]{2}{*}{ foszforiláció (ph) } & szerin (S) & $\mathrm{H} 2 \mathrm{~B}, \mathrm{H} 3, \mathrm{H} 4$ & H3S10ph \\
\hline & treonin $(\mathrm{T})$ & $\mathrm{H} 3$ & H3T3ph \\
\hline ubiquitináció (ub) & lizin $(\mathrm{K})$ & $\mathrm{H} 2 \mathrm{~A}, \mathrm{H} 2 \mathrm{~B}$ & H2BK120ub \\
\hline sumoiláció (su) & $\operatorname{lizin}(\mathrm{K})$ & $\mathrm{H} 2 \mathrm{~A}, \mathrm{H} 2 \mathrm{~B}, \mathrm{H} 4$ & H2BK6su \\
\hline ADP-riboziláció (ar) & glutaminsav ('E) & $\mathrm{H} 2 \mathrm{~A}, \mathrm{H} 2 \mathrm{~B}, \mathrm{H} 3, \mathrm{H} 4$ & H2BE2ar1 \\
\hline deimináció (cit) & arginin ('R) & $\mathrm{H} 3, \mathrm{H} 4$ & H3R2cit \\
\hline izomerizáció (iso) & prolin $(\mathrm{P})$ & $\mathrm{H} 3$ & H3P38iso \\
\hline
\end{tabular}

1. táblázat: A hiszton fehérjéken megjelenő leggyakoribb poszttranszlációs módosítások A táblázat összeállítása a [10] és a [11] források alapján történt.

\subsection{A hiszton fehériék poszttranszlációs módosításainak a kromatin szerveződésére} kifejtett hatásai

A hiszton fehérjék N-terminális régióján lejátszódó poszttranszlációs módosítások egyike azoknak a folyamatoknak, amelyek hozzájárulnak a kromatinszerkezet dinamikus átalakításához. A szakirodalom jelenleg többféle modellel magyarázza azt, hogy ezek a poszttranszlációs módosítások hogyan vesznek részt a génműködés szabályozásában, viszont a pontos mechanizmus még nem ismert. Számos kísérletes bizonyíték támasztja alá mind egy cisz, mind egy transz hatású mechanizmus müködését.

A cisz mechanizmus modellje szerint a létrejövő módosítások a hiszton-DNS vagy hiszton-hiszton kölcsönhatás módosításán keresztül megváltoztatják a nukleoszómák szerkezetét, valamint a nukleoszómák között kialakult kapcsolatokat, amely hatások végül a kromatinszerkezet átrendeződéséhez vezetnek [11] (6. ábra). A hisztonok acetilációja és foszforilációja csökkenti a hisztonok pozitív töltését, ezáltal meggyengíti a hiszton fehérjék és a negatív töltésű DNS közötti kölcsönhatást, ami az internukleoszómális kapcsolatok gyengüléséhez vezet. A hisztonok N-terminális doménjének acetilációja maguknak a nukleoszómáknak a stabilitását nem befolyásolja, viszont az adott nukleoszómát felépítő hiszton oktamer és a szomszédos „linker” DNS közötti kapcsolatot gyengíti, és ezáltal gátolja a tömörebb kromatinszerkezet kialakulását [12]. Ennek következtében a hisztonok hiperacetilált állapotát egy nyitottabb, aktívabb kromatinszerkezettel, míg hipoacetilált állapotát egy tömörebb, represszív struktúrával hozzák összefüggésbe. In vitro kísérletek azt mutatták, hogy a H4 hiszton fehérje N-terminális doménjének acetilációs állapota (16-25. aminosavakon) meghatározó szerepet tölt be a kompaktabb kromatinszerkezet kialakításában, 
ugyanis ezek a bázikus aminosavak kölcsönhatnak a szomszédos nukleoszóma H2A-H2B dimerjének savas aminosavaival [6]. A H4 hiszton 16-os lizinjének acetilációja csökkenti a kromatin szálak közötti kölcsönhatások létrejöttét, ezáltal gátolja egy tömörebb kromatin struktúra kialakulását [13]. Az ilyen cisz mechanizmusú hiszton módosítások általában kumulatív módon fejtik ki hatásukat a kromatin szerveződésére [14].

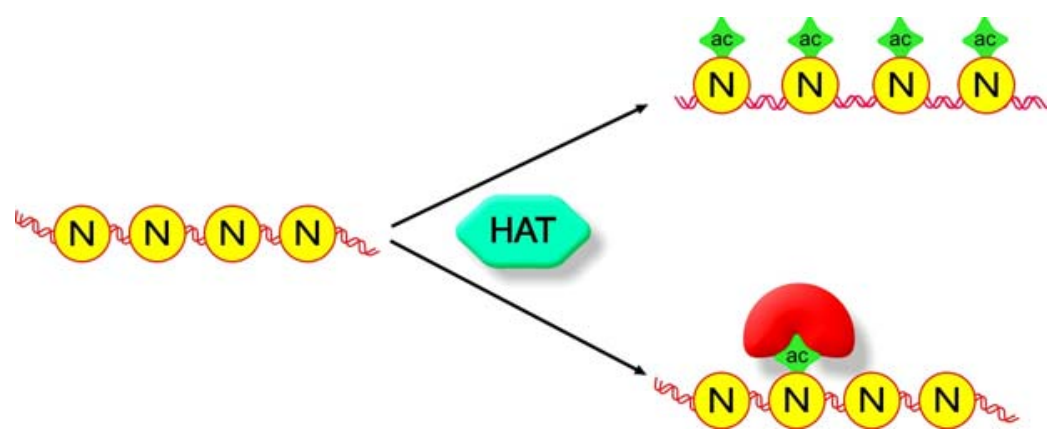

5. ábra: A hiszton acetiláció a kromatin szerveződésére kifejtett cisz illetve transz mechanizmusa (HAT=hiszton acetiltranszferáz, ac= acetiláció, $\mathrm{N}=$ nukleoszóma)

Egy másik elképzelés szerint a hisztonok poszttranszlációs módosításai egy transz mechanizmus által hatnak a kromatinszerkezetre. Eszerint a modell szerint a hisztonokon megjelenő módosítások különböző nem-hiszton fehérjék - például kromatinszerkezetet átrendező komplexek vagy transzkripciós faktorok - kötőhelyéül szolgálnak (5. ábra). A poszttranszlációs módosítások egy összetett kódot hoznak létre, amelyek speciális mintázatát az arra specifikus hiszton-kötő doméneket tartalmazó fehérjék felismerik. Ilyen, módosított hiszton fehérjét kötő fehérjedomén például a metilált lizint felismerő kromodomén, vagy az acetilált lizint felismerő bromodomén [15]. Ezek a fehérjék általában csak egy meghatározott pozícióban megjelenő módosítást ismernek fel, mint ahogyan a HP1 fehérje kromodoménje specifikusan a 9-es lizinjén trimetilált H3 hisztonokat ismeri fel és köti. A nem-hiszton fehérjék által felismert módosítási mintázatok lehetnek ugyanazon a hiszton fehérjén, ekkor cisz mintázatról beszélünk, míg ha különböző hiszton fehérjéken jelennek meg, akkor transz mintázatról beszélünk. A cisz mintázat egyik jól jellemzett példája a H3 hiszton fehérje 10-es szerinjének foszforilációja (H3S10ph) és a 14-es lizinjének acetilációja (H3K14ac) közötti kapcsolat, amikor is a H3S10 foszforiláció fokozza a 14-es lizint acetilációját végző enzim nukleoszómához kötődését [16]. Ugyancsak cisz típusú módosítási mintázat jön létre a CBP acetiltranszferáz és a CARM1 metiltranszferáz együttmüködése révén. Ennek során ösztrogén stimuláció hatására a CBP a kromatinhoz kötődik és a H3 hiszton 18-as, majd a 23-as lizinjét acetilálja, amely elősegíti a CARM1 metiltranszferáz kromatinhoz kötődését és a 17-es 
arginin metilációját [17]. A különbözö hiszton fehérjéken megjelenő, ún. transz mintázat egyik példája, hogy a $\mathrm{H} 3$ hiszton 4-es lizinjén történő metiláció előfeltétele a H2B hiszton 123-as lizinjének előzetes ubiquitinációja [18].

Ez utóbbi modellen alapszik a hiszton kód hipotézis, mely szerint a hisztonok különböző aminosavain megjelenő módosítások kombinációja egy kódként szolgál ahhoz, hogy az adott biológiai folyamat megvalósulásához szükséges kromatinszerkezet kialakuljon. Ezt a kódot egymással antagonista hatású enzimek „írják” illetve „törlik”, specifikus felismerő fehérjék „fordítják le”, amely során indukálják a kódnak megfelelő kromatinszerkezet kialakítását [19]. A felismerést és „fordítást” végző fehérjék lehetnek további hiszton módosító enzimek, vagy a nukleoszómákat ATP-ből származó energia felhasználásával elmozdító fehérjék, ún. „ATP-függő kromatin remodeling complexek”, illetve a különböző funkcióval rendelkező hiszton variánsok kromatinba épülését elősegítő faktorok is [20]. A legegyszerübb kódot az jelentené, ha egy adott módosítás közvetlenül egy adott folyamattal lenne összekapcsolható, mint például ha egy adott hiszton módosítás megjelenésének a következménye minden esetben a génaktiváció lenne [21]. Valójában a kód nem ennyire egyszerü, ugyanis előfordul, hogy ugyanaz a módosítás több, különböző jelentéssel is bír, mint például a H3 hiszton 10-es szerinjének foszforilációja egyrészt kódként szolgál a transzkripció aktivációjához szükséges nyitott kromatinszerkezet kialakításához, másrészt a sejtosztódás során kialakuló, rendkívül tömör kromatin kialakításában is részt vesz [22].

\section{$\underline{1.4 \text { A hiszton acetiláció és a transzkripció kapcsolata }}$}

A hiszton fehérjék acetiláltsági állapota a kromatinszerkezet szabályozásának egy igen fontos eleme, és számos folyamat során, mint például a DNS replikáció, a rekombináció, a DNS hibajavítás és a transzkripció, is fontos funkciót lát el. Az acetiláltsági állapotot egymással antagonista hatású hiszton acetiltranszferáz (HAT) és hiszton deacetiláz (HDAC) komplexek alakítják ki és tartják fenn a sejtben.

Az egyik hiszton acetiláció által szabályozott folyamat a nukleoszómák összeszerelése, a kromatinszerkezet felépülése. A sejtciklus szintézis fázisában a kromatinba történő beépítéshez az újonnan képződő hiszton fehérjék egy acetilációs mintázatot kapnak, amely a beépítést segítő hiszton chaperon fehérjék számára jelként szolgál az újonnan 
szintetizált hiszton fehérjék azonosítására. A beépítést követően HDAC komplexek rövid időn belül (kb. 20 perc) eltávolítják ezt a módosítási mintázatot [23].

A hisztonok acetilációs állapota a kromatin dekondenzálódása során is fontos szabályozó funkcióval bír, a hiperacetilált állapotot egy nyitottabb, fellazult kromatinszerkezettel, míg a hipoacetilált nukleoszómákat egy tömörebb, zártabb szerkezettel hozzák összefüggésbe. A pontos mechanizmus, amellyel az acetiláció hozzájárul a kromatin tömörségének módosításához részleteiben még nem ismert. Számos kísérletes bizonyíték igazolja a fent említett közvetlen, illetve a felismerö fehérjék által megvalósuló mechanizmusok működését is. Az acetilációnak a hisztonok pozitív töltését neutralizáló hatását és ennek funkcionális jelentőségét támasztják alá a H3 hiszton 56-os lizinjének acetilációjával kapcsolatos megfigyelések. A H3 hiszton 56-os lizin aminosava a globuláris domén területén, a nukleoszóma azon részén található, ahol a DNS be-, illetve kilép a nukleoszómából. Ezen aminosav acetilálódásakor bekövetkező töltésváltozás miatt gyengül a DNS és a hiszton oktamer közötti kapcsolat, amely destabilizálja a nukleoszómát [24]. Az acetiláció úgy is hozzájárul a kromatinszerkezet felnyitásához, hogy a hisztonokon megjelenő acetilációs mintázat kötőhelyül szolgál különböző, a génaktivációban részt vevő, bromodoménnel rendelkező fehérjék számára. Az SWI/SNF (switch/sucrose nonfermentable) kromatin remodeling complex is rendelkezik bromodoménnel, amellyel csak a SAGA (ㅁpt-

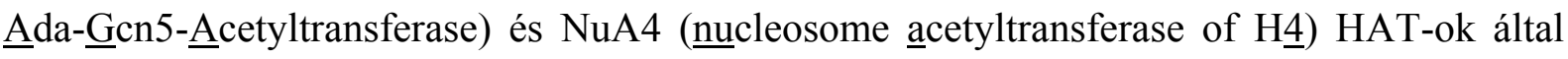
acetilált nukleoszómákhoz képes stabilan kötődni, majd a transzkripció aktivációjához ATP energiájának felhasználásával eltávolítja azokat [25]. Ezzel ellentétesen az acetilációs mintázat eltávolítása egyrészt gátolja az acetillizint kötő transzkripciós faktorok és koaktivátorok kötődését, valamint elősegíti SANT (ㅁwi3-Áda2-NַCoR-TFFIIIB) domént tartalmazó, represszor fehérjék kötődését. A SANT domén számos korepresszor fehérjében előforduló motívum, amelynek azt a funkciót tulajdonítják, hogy felismeri és kötődik a poszttranszlációsan nem módosított hiszton fehérjékhez [26]. Nemcsak represszorokra, hanem a transzkripciós gátlást közvetítő fehérjékre is jellemző a SANT domén, például a gátlást megvalósító kromatin remodeling komplex, az ISWI (imitation switch) is tartalmaz nemacetilált hisztonokat kötő SANT domént [27].

Az acetilációnak génműködés szabályozásában betöltött szerepére az első közvetlen bizonyítékot a nukleoszómális hisztonok acetilációját és deacetilációját végző enzimek azonosítása adta. Az elsőnek azonosított HAT enzim, a p55 élesztő homológjáról (yGcn5 general control nnonderepressible $\underline{5}$ ) már korábban kimutatták, hogy kölcsönhat transzkripciós aktivátorokkal [28], míg az első hiszton deacetiláz enzimet, az Rpd3 fehérjét korábban 
transzkripciós represszorként azonosították élesztöben (yRpd3 - reduced potassium deficiency 3) [29]. Azóta több, jól ismert transzkripciós koaktivátor és korepresszor fehérjéről kimutatták, hogy vagy kölcsönhat, vagy rendelkezik HAT illetve HDAC enzimatikus aktivitással, amelyek alapvető jelentőséggel bírnak a génexpresszió szabályozásában [30].

$\mathrm{Az}$ acetiláció-deacetiláció folyamata kétféle módon járul hozzá a transzkripció szabályozásához: egyrészt kimutatható egy irányított, különböző szabályozó szekvenciákon megjelenő acetiláció, valamint egy általános, az egész genomra kiterjedő acetilációs mintázat is. A HAT és HDAC komplexek egyrészt irányítottan, a transzkripciót szabályozó fehérjékkel - aktivátorokkal vagy represszorokkal - együtt közvetlenül kötődnek a gének szabályozó szekvenciáihoz és specifikusan ezeken a helyeken módosítják a hisztonokat és ezáltal hozzájárulnak a kromatinszerkezet megváltoztatásához [13]. A hiszton acetiláció ilyen jellegü transzkripciós szabályozó szerepéről a következő elképzelés született: a transzkripciós aktivátor fehérjék DNS-hez kötődése kiváltja a HAT-ok kromatinhoz kötődését, amelyek a nukleoszómális hisztonok acetilációján keresztül egy, a transzkripcióhoz szükséges nyitottabb kromatinszerkezetet hoznak létre. Ez a specifikus acetilációs mintázat további HAT-ok, transzkripciós faktorok vagy kromatin remodeling komplexek kötődésén keresztül egy nyitottabb kromatinszerkezet kialakulásához vezet, amely lehetővé teszi a transzkripció iniciációját. Ezzel ellentétesen a transzkripciós represszor fehérjék szabályozó DNS szekvenciákhoz kötődése HDAC fehérjék kapcsolódását váltja ki, amelyek a nukleoszómális hisztonok acetiláltságát csökkentve egy tömörebb, transzkripciósan inaktív kromatinszerkezet kialakítását indukálják [21] (6. ábra).

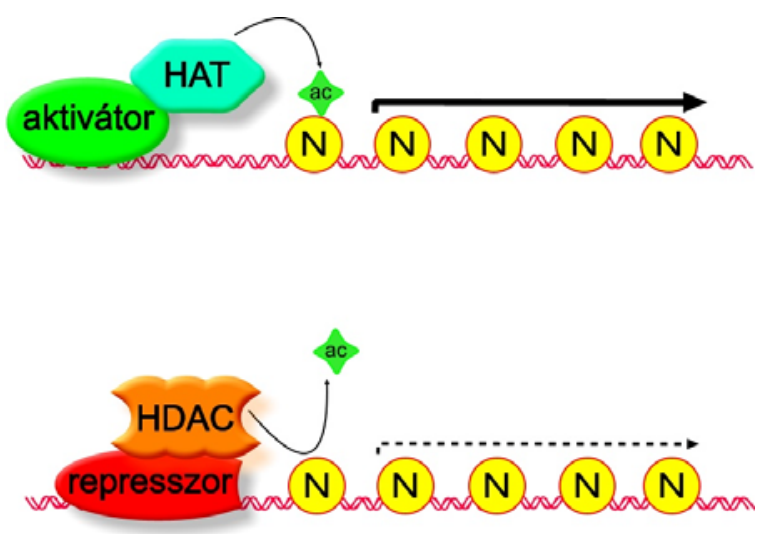

6. ábra: A DNS-kötő transzkripciós faktorok hiszton acetiltranszferázok (HAT) és hiszton deacetilázok (HDAC) segítségével alakítják ki a müködésüknek megfelelö kromatinszerkezetet. $(\mathrm{ac}=$ acetiláció, $\mathrm{N}=$ nukleoszóma) 
Emellett mind a HAT, mind a HDAC komplexek részt vesznek a szekvencia specifitástól mentes, az egész genomra kiterjedő, általános acetilációs mintázat kialakításában is [13]. Az élesztő yGcn5 HAT-ról kimutatták, hogy a koaktivátor funkciója mellett részt vesz egy ilyen jellegü általános acetilációs mintázat kialakításában is, amely során mind kódoló, mind intergenikus régiókban nagy, összefüggő kromatin domének acetilációját végzi [31]. A transzkripciós aktivátorok által irányított acetilációhoz hasonlóan ez az általános acetiláció is fokozza a génexpressziót, például a yGen5 által létrehozott általános acetiláció a PHO5 és más promóterek transzkripciós alapaktivitását is növelte [32]. Az elmúlt évtized során a hiszton acetiláció szerepét intenzíven vizsgáló tanulmányok azt az elképzelést alakították ki, hogy az acetiláció génaktivációt, míg a deacetiláció repressziót eredményez, viszont a legújabb eredmények azt mutatják, hogy ez a folyamat korántsem ennyire egyszerü. A Pho4 aktivátor fehérje a még represszált állapotú PHO5 promóterhez kötődésének a NuA4 HAT komplex által létrehozott acetiláció az előfeltétele [33]. Ebben az esetben úgy tünik, hogy a NuA4 komplex általi acetiláció megteremti a gén indukálhatóságát, míg egy másik HAT, a SAGA komplex müködése révén aktiválódik a PHO5 gén [34]. Ehhez hasonlóan számos más indukálható promóter esetében azt tapasztalták, hogy még a represszált állapotukban, a későbbi aktiválhatóságuk céljából acetiláltak [31]. Ezekhez az eredményekhez hasonlóan számos HDAC-ról is kiderült, hogy a transzkripció iniciációja során is fontos funkciót látnak el. Például a Hos2 HDAC hiányában több, aktívan átíródó gén kódoló régióján megemelkedik a H3 és H4 hisztonok acetilációja, és ezzel együtt zavart szenved ezen gének transzkripiójának aktivációja [35]. Az ozmotikus stressz, valamint a hősokk által indukált gének aktivációja során az Rpd3 HAT kötődik ezekhez a génekhez, amelyek területén a H4 acetiláció szintje le is csökken [36]. Hogy hogyan valósul az meg, hogy ugyanannak a HATnak illetve HDAC-nak a müködése egyszer génaktivációt, máskor pedig repressziót eredményez, még nem tisztázott.

\subsubsection{A hiszton acetiltranszferázok}

A HAT fehérjék acetilcsoport áthelyezését katalizálják acetil-koenzim A-ról a hiszton fehérjék lizin aminosavainak $\varepsilon$-amino csoportjaira. Az alapján, hogy a kromatinszerkezetbe beépült hisztonokat módosítanak-e, két nagy csoportját különítjük el a HAT-oknak. Az Atípusú HAT-ok sejtmagi elhelyezkedést mutatnak és a nukleoszómális hisztonokat acetilálják, így a transzkripció folyamatával összefüggő hiszton acetiláció létrehozásáért felelősek. Ezzel 
szemben a B-típusú HAT-ok a citoplazmában az újonnan szintetizálódott hiszton fehérjéket módosítják, és ezáltal az új hisztonok nukleoszómákba épülését segítik elő [37].

A hiszton acetiltranszferáz fehérjék másik típusú csoportosítása a katalítikus doménjükben megjelenő hasonlóságok alapján történik [38]. Ezek alapján a HAT-ok öt nagy

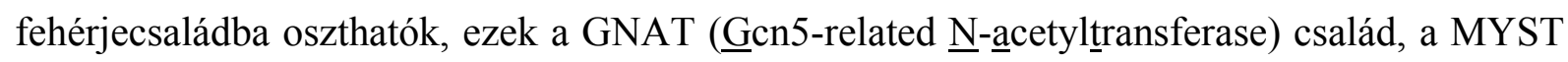

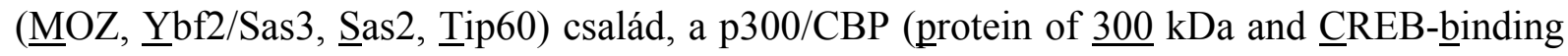
protein), a TAF1 (TATA box-binding protein-associated factor 1) és az SRC (steroid receptor coactivator) család [39].

\subsubsection{A GNAT acetiltranszferáz család}

A GNAT családba tartozó fehérjék közös jellemzője, hogy az acetiltranszferáz doménjükben megtalálható három vagy négy, egyenként 15-33 aminosavból álló konzervált motívum [40]. Ezen felül a család számos tagjánál megtalálhatóak hasonló szerkezetü és funkciójú domének, mint például az Ada2 (alternation/deficiency in activation-2) koaktivátorral kölcsönható régió, vagy a C-terminálisan elhelyezkedő bromodomén, amely a nukleoszómális hisztonok acetilált lizinjeihez képes kötődni (7. ábra) [40]. A család egyik legismertebb és legjobban jellemzett tagja - amelyről a család a nevét is kapta - a Saccharomyces cerevisiae-ben transzkripciós aktivátorként azonosított yGen5 fehérje. A yGcn5 fehérje Tetrahymena thermophila homológja volt az első enzim, amely A-típusú hiszton acetiltranszferáz enzimaktivitását kimutatták, és ezzel igazolták a közvetlen kapcsolatot a hiszton acetiláció és a transzkripció szabályozása között. Ezen HAT funkció evolúciósan erősen konzervált tulajdonságát mutatja, hogy azóta számos modellorganizmusban (például Arabidopsisban, Drosophila-ban, egérben, emberben is) azonosították a yGcn5 fehérje homológját [41]. A Drosophila (d) Gcn5 fehérje a yGcn5 fehérjéhez hasonlóan rendelkezik a családra jellemző, konzervált HAT doménnel, egy bromodoménnel [42]. Emellett a dGcn5 esetében is a HAT és bromodomén közötti, közel 100 aminosavas régió tehető felelőssé az ADA2 fehérjékkel lértejött kölcsönhatás kialakításáért [43, 44]. Ezeken felül a dGcn5 fehérje N-terminális végén található egy, a humán PCAF (p300/CBBP-associated factor) fehérje N-terminális doménjével nagyfokú homológiát mutató ún. PCAF homology domén. A humán PCAF HAT esetében ez a régió a CBP/p300 hiszton acetiltranszferázzal való kölcsönhatás kialakításáért felelős [42]. 


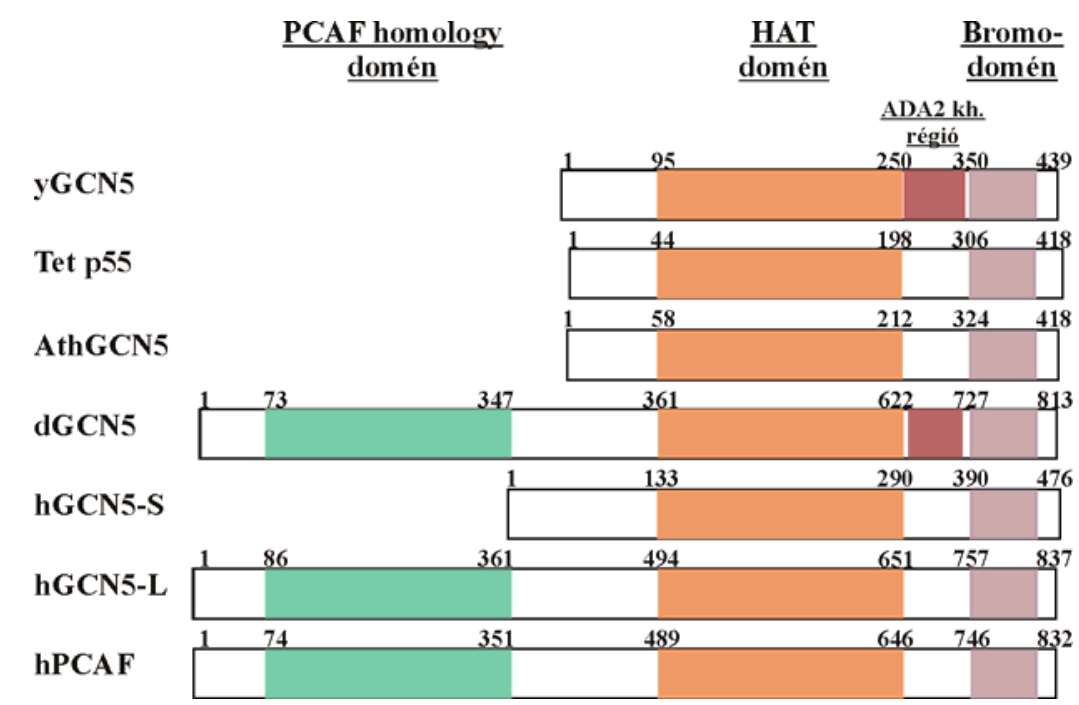

7. ábra: A GNAT családba tartozó homológ Gcn5 hiszton acetiltranszferáz fehérjék doménszerkezete

A humán (h), a Drosophila (d), a Saccharomyces cerevisiae (y), a Tetrahymena thermophila (Tet) és az Arabidobsis thaliana (Ath) Gcn5 fehérjék esetében a GNAT családra jellemző HAT, Bromo- és PCAF homology domének elhelyezkedése látható. Az ábra a [42] és [44] források alapján készült.

A legtöbb hiszton acetiltranszferáz enzim in vivo nem önmagában, hanem több alegységes fehérje komplex tagjaként fordul elő. A komplexekben kialakuló különböző fehérje-fehérje kölcsönhatások alapvetően meghatározzák a HAT-ok enzimaktivitását és szubsztrát specifitását [39]. Számos HAT a komplex többi alegysége nélkül nem képes a kromatinba épült hisztonok acetilációjára; illetve önmagában más lizineket módosít, mint komplexbe épülve. A yGcn5 fehérje önmagában nem, csak többalegységes enzim komplexek, így pl. a SAGA vagy az ADA komplex részeként képes a nukleoszómális hisztonokat acetilálni [45]. A HAT-ok komplexekbe épülése megváltoztatja azok lizin specifitását: így például míg a yGcn5 fehérje önmagában szabad hiszton fehérjéken elsősorban a H3 hiszton 14-es lizinjét acetilálja, addig a SAGA komplex alegységeként a nukleoszómális H3 9-es, 14es, 18-as és 23-as lizinjeit, az ADA komplexben föként a H3 hiszton 9-es, 14-es és 18-as lizinjeit acetilálja [46]. Élesztőben eddig négy Gen5-tartalmú HAT komplexet azonosítottak: a SAGA, a SLIK/SALSA, az ADA és a HAT-A2 komplexeket [13]. Ezek katalitikus alegységét a yGcn5 fehérje mellett két adaptor fehérje, az yAda2 és az yAda3, valamint az ySgf29 fehérje alkotja, amelyek együttesen alakítják ki a Gcn5 fehérje szubsztrát kötési képességét és lizin specifitását [47] [48]. 


\subsubsection{A SAGA komplex}

Az egyik legrészletesebben jellemzett Gcn5 tartalmú HAT komplex az élesztő SAGA. A ySAGA 1,8 MDa tömegü, evolúciósan konzervált kromatin módosító komplex, amely kétféle hiszton módosító aktivitással (acetiláció és deubiqitináció) rendelkezik. Az élesztő ySAGA és a magasabbrendủ eukariótákban megtalálható ortológjainak vizsgálata sok fontos információval szolgált a hiszton módosítások transzkripció aktivációban betöltött szerepének részletesebb megértéséhez [49].

A ySAGA a transzkripció aktiváció szabályozása - amely a legrészletesebben jellemzett aktivitása - mellett a transzkripció elongációs fázisában és az mRNS export folyamatában is közremüködik [50]. Felépítését tekintve a ySAGA komplex több funkcionális modulra különíthető el (8. ábra). A komplex fő szerkezeti vázát az ySpt3, ySpt7, ySpt8, ySpt20, yAda1, yTra1, yTAF5, yTAF6, yTAF9, yTAF10 és yTAF12 fehérjék alkotják, amelyek egy SPT és egy TAF modullá állnak össze. Ezenfelül a komlex a yTral alegységen keresztül kapcsolatot alakít ki különböző aktivátor fehérjékkel, és ezáltal képes a komplex megfelelő genomi régiókhoz kapcsolódik. Az ySpt3 és ySpt8 fehérjéből összeálló egység kölcsönhatást alakít ki a TBP-vel (TATA Binding Protein), amely a transzkripciós iniciációs komplex összeszerelődésén keresztül segíti a transzkripció aktivációját. A komplex egyik enzimatikus aktivitással rendelkező egysége a yGcn5, yAda2, yAda3 és ySgf29 fehérjékből felépülő acetilációs modul, amely a nukleoszómális hisztonok acetilációját végzi. Az általa létrehozott acetiláció mind a transzkripció aktiváció, mind a transzkripció elongáció folyamata során hozzájárul egy hozzáférhetőbb kromatinszerkezet kialakításához. A ySgf29 fehérje a 4-es lizinjén trimetilált H3 hiszton (H3K4me3) fehérjéhez képes kapcsolódni, ezáltal kapcsolatot teremt az aktivációs jelként azonosított H3K4me3 hiszton kód és a hiszton acetiláció között. Emellett megtalálható a ySAGA-ban egy, az yUbp8, ySus1, ySgf11 és ySgf73 fehérjékből felépülő deubiquitinációs enzimaktivitással rendelkező egység (DUBm) is, amely a H2B hiszton 123-as lizinjén található ubiqutin módosítás eltávolításával elősegíti a transzkripció elongációját. Az ySgf73, az ySgf11 és az ySus1 alegységek részt vesznek az mRNS-export folyamatát végző faktorok és a komplex között létrejövő kölcsönhatás kialaításában, ezáltal a deubiquitinációs egység az mRNS transzportjára is kiterjeszti a ySAGA komplex összetett szabályozó funkcióját [13] [48] [51] [52] [53]. 


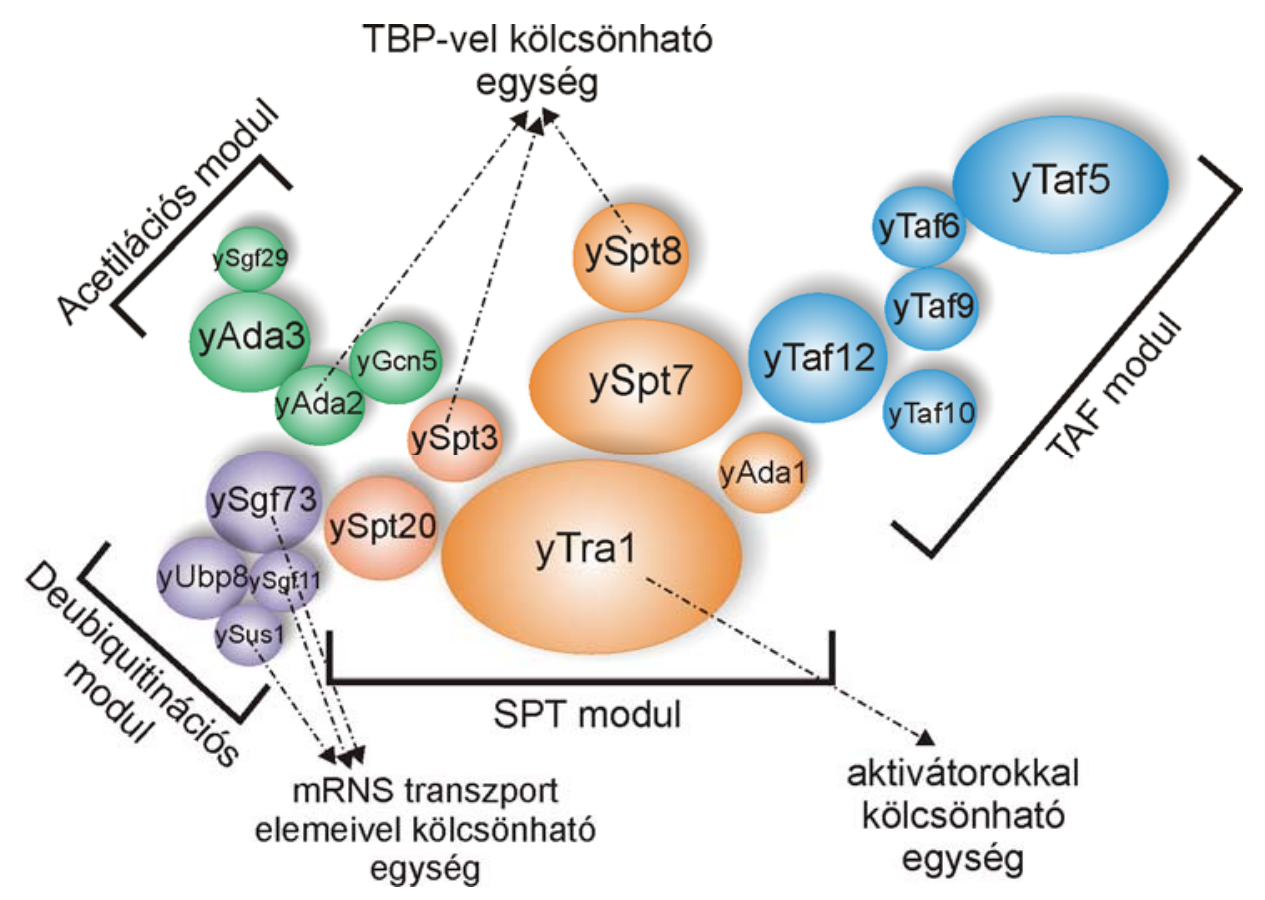

\section{8. ábra: A ySAGA komplex sematikus rajza}

Különböző színekkel ábrázolva láthatóak a ySAGA komplex funkcionális moduljai, valamint a szaggatott nyilak utalnak az egyes alegységeknek a transzkripció folyamata során betöltött különböző szerepére. Az ábra a [48] forrás alapján készült.

\subsubsection{Ada2 adaptor fehérjék}

A SAGA komplexen belül kialakuló fehérje-fehérje kölcsönhatások együttesen alakítják ki az egyes modulok pontos funkcióját. Az acetilációs modul esetében az azt felépítő adapter fehérjék közül az yAda3 határozza meg a yGcn5 fehérje kiterjedt lizin specifitását, az yAda2 fehérje pedig erősíti a yGen5 HAT aktivitását és elősegíti annak nukleoszómális hisztonokhoz való kötődését [47]. A katalitikus egység kialakulásához a yGcn5 fehérje az yAda2 erősen konzervált amino-terminális régiójával alakít ki kapcsolatot, míg az yAda2 fehérje középső szakasza felelős az yAda3 fehérjével létrejövő kölcsönhatásért [54]. Az yAda adaptorok fontos funkciót töltenek be a transzkripció szabályozása során az aktivátor domén és az alap transzkripciós apparátus közötti fizikai kapcsolat kialakításában is. Erre utal, hogy az yAda2 fehérje közvetlen kölcsönhatást alakít ki a herpesz vírus VP16 fehérje aktivátor doménjével és az alap transzkripciós faktorok közül a TBP (TATA-binding protein) fehérjével is, valamint hogy az yAda2 fehérje jelenléte szükséges az aktivátor domén és a TBP közötti kölcsönhatás létrejöttéhez [55].

Az Ada2 típusú adaptor fehérjék az eukarióta transzkripció szabályozásában betöltött jelentős funkciójára utal, hogy a különböző fajokból származó Ada2 fehérjék felépítése 
erősen konzervált. Minden, az Ada2 családba tartozó fehérje rendelkezik két konzervált doménnel: egy ZZ cink-ujj doménnal és egy SANT doménnal. Mindkét domén jelenlétére szükség van a yGcn5 és a VP16 aktivációs doménnel való kölcsönhatás létrejöttéhez, viszont a domének ennél pontosabb funkciója még nem teljesen tisztázott [54]. Az eddigi információk szerint az yAda2 fehérje SANT doménje részben a yGcn5 fehérjéhez kötődéshez, részben pedig a kromatinba épült hisztonok felismeréséhez és kötéséhez szükséges, így jelentős funkciót tölt be a ySAGA komplex acetilációs aktivitásának meghatározásában [56]. Az ADA2 fehérjecsalád tagjai az elöbb említett két domén mellett rendelkeznek több konzervált, $\alpha$-helikális szerkezetü motívummal, amelyeket ADA motívumnak nevezünk. Ezek az ADA motívumok a histon-fold motívumokra jellemző ( $\alpha$-hélix $)_{1}^{-}(\text {loop })_{1}-(\alpha \text {-hélix })_{2}-(\text { loop })_{2}-(\alpha-$ hélix) $)_{3}$ mintázatot hordoznak, amelyek nemcsak hiszton fehérjékben, hanem különböző adaptor, koaktivátor komplexek számos alegységében is előfordulnak [57]. Ezek alapján feltételezhető, hogy ezeknek az ADA motívumoknak az ADA2 fehérjék más komplex alegységekkel kialakított kölcsönhatásainak létrejöttében fontos szerepe lehet.

\subsubsection{Drosophila Gen5-tartalmú HAT komplexek}

A ySAGA komplex acetilációs egységét felépítő yGcn5, yAda2, yAda3 fehérjék homológjai Drosophila-ban is megtalálhatóak. Ehhez hasonlóan a Drosophila melanogasterben is két ADA2 fehérjét - dADA2a és dADA2b - azonosítottak [58]. Mindkét Drosophila ADA2 fehérje rendelkezik a családra jellemző, konzervált ZZ cink-ujj doménnal, SANT doménnal, valamit három ADA motívummal. Élesztő kettős hibrid és koimmunprecipitációs kísérletekben mind a dADA2a, mind a dADA2b fehérje kölcsönhatást mutatott a dGen5, valamint a dADA3 fehérjékkel, viszont a ySAGA komplexre specifikus alegységek Drosophila homológjaival csak a dADA2b fehérje esetében detektáltak interakciót. Az élesztő homológ Ada2-höz hasonlóan mindkét Drosophila ADA2 fehérje egyegy HAT aktivitású modul felépítésében vesz részt, viszont ezek két eltérő összetételü és funkciójú Gcn5-tartalmú komplexet hoznak létre [58] [59] (9. ábra). Számos magasabbrendü eukarióta genom - mint például az Arabidobsis thaliana [60] és a humán genom [54] is két, az élesztő Ada2-vel homológ gént tartalmaz.

A dGcn5, a dADA3 és a dSgf29 (élesztő ySgf29 Drosophila ortológja) fehérje a dADA2a adaptorral együtt egy HAT modult alkot, amely a700 kDa méretű dATAC (ㅁA two a containing) komplex egyik katalitikus egységét képezi [61] (9. ábra). Ezek a fehérjék 
képezik a dATAC és a dSAGA komplexek közös komponenseit. A dATAC komplex a dGcn5 fehérjén kívül rendelkezik még egy, attól független HAT aktivitású alegységgel, a dATAC2 fehérjével [62]. Eddig a komplex további nyolc alegységét (dATAC2, dATAC3, HCF, WDS, D12, NC2 $\beta$, CG10238 és CHRAC14) azonosították [63].

A dADA2b, a dGcn5, dADA3 és a dSgf29 fehérje által kialakított HAT modul egy 2 MDa méretü komplexbe épül be, amely az élesztő ySAGA komplex Drosophila megfelelőjének (dSAGA) tekinthető [64] (9. ábra). A dSAGA komplex számos, az élesztő SAGA alegységekkel homológ fehérjéjét azonosították. A ySAGA komplex felépítése és funkciója is erősen konzervált, így modellként szolgálhat a Drosophila dSAGA komplex müködésének és szabályozó funkciójának megértéséhez. Így az acetilációs modulon (dGcn5, dADA2b, dADA3, dSgf29) felül az SPT és TAF egység egyes tagjait, az dAda1, dSpt20, a dSpt7 (ySpt7 ortológ), a dWda (yTaf5 ortológ), dSaf6 (yTaf6 homológ), dTaf9, dTaf10b (yTaf10 homológ) és a dTaf12 fehérjét is azonosították Drosophila-ban [58] [59] [64] [65]. A TBP-vel kölcsönható fehérjék közül eddig csak a ySpt3-nak megfelelő dSpt3 fehérjét találták meg Drosophila-ban. A dSAGA komplex a yTra1 fehérjével ortológ dTra1 (Nipped-A) alegységen keresztül képes a különböző transzkripciós szabályzó faktorokkal kölcsönhatást kialakítani [66]. A deubiquitinációs modult felépítő faktorokból eddig a dNonstop (yUbp8 ortológ), az dSgf1 1 (ySgf11 ortológ) és a dE(y)2 (ySus1 ortológ) fehérjét azonosították [67] [68].

A fent részletezett két Gcn5-tartalmú Drosophila HAT komplex eltérő alegységösszetétele arra utal, hogy a két komplex eltérő funkcióval rendelkezhet. A két komplex a acetilációs modulja csak az dADA2 fehérjékben különbözik egymástól.
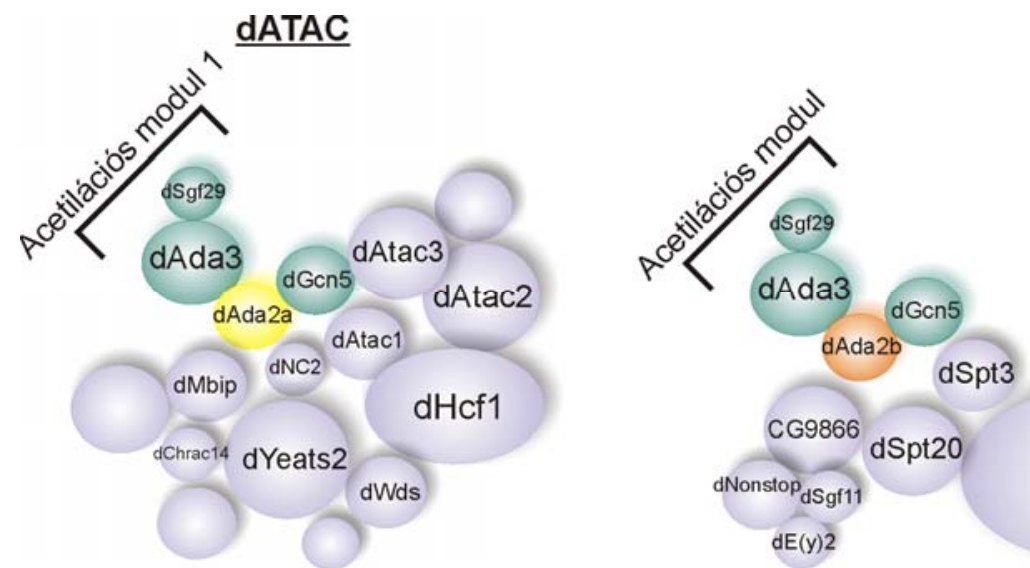

dSAGA

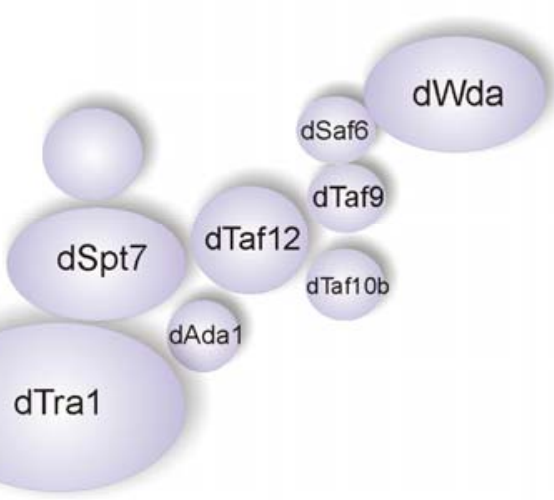

\section{9. ábra: A Drosophila dGcn5-tartalmú HAT komplexek sematikus rajza}

Az ábra a [48] és [69] alapján készült. 
Az acetilációs modulok közös komponenseinek hiányában (dGen5 és dADA3) meghatározták, hogy a Drosophila Gen5-tartalmú HAT komplexek mind H3, mind H4 hisztonra specifikus acetilációs aktivitással rendelkeznek. A H3 hiszton 9-es és 14-es pozícióban található lizinjeit, valamint a H4 hiszton 5-ös és 12-es lizinjeit acetilálják [70] [71]. Az egyik, illetve a másik komplexre specifikus dADA2 fehérje funkciójának gátlásával meghatározták, hogy a dADA2b tartalmú dSAGA komplex specifikusan a H3 hiszton 9-es és 14-es lizinjét acetilálja, míg a dADA2a alegységet tartalmazó dATAC komplex dGcn5 specifikus HAT aktivitása a H4 hiszton 5-ös és 12-es lizinjére irányul [70] [72] (10. ábra).

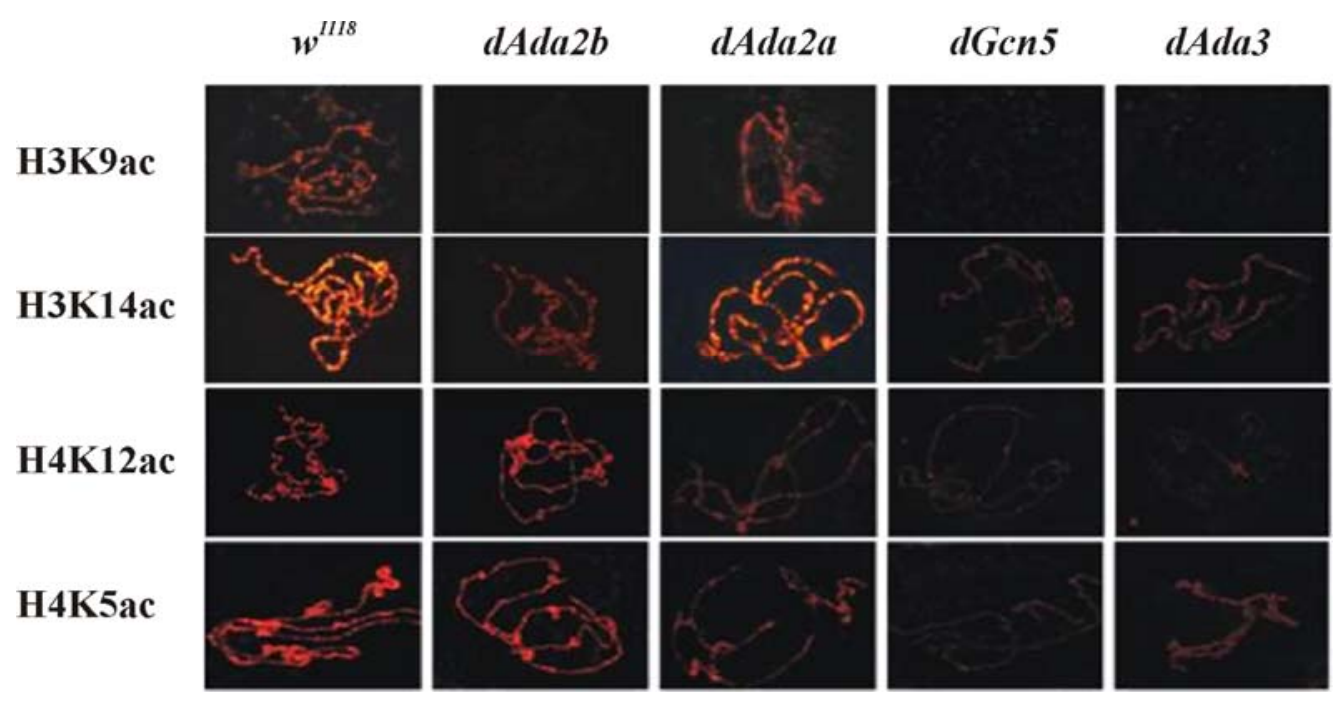

10. ábra: Drosophila Gen5-tartalmú HAT komplexek acetilációs aktivitása

$\mathrm{Az}$ ábrán nyálmirigy óriáskromoszómák immunfestése látható, amely a dGcn5 és dADA fehérjék hiányában tapasztalt H3 és H4 hisztonok acetilációs szintjét mutatja. Az ábra a [44] [70] [71] [72] források alapján készült.

\subsubsection{Drosophila ADA2b fehérjék}

Az ADA2 fehérjék sokszínü funkciójára utal, hogy a Drosophila Ada2b génről több mRNS és fehérje izoforma termelődik [73]. Kutatócsoportunk korábban már igazolta, hogy az egyedfejlődés főbb szakaszaiban (embrió, lárva, báb, imágó állapot) a $d A d a 2 b$ génről alternatív splicing során valójában két mRNS forma (dAda2bS és dAda2bL) képződik [72]. A két mRNS 5' végi régiója teljesen megegyezik egymással, csak a 3. és 4. exon területén különböznek, ahol a leolvasási keret is eltérő (11. ábra). 


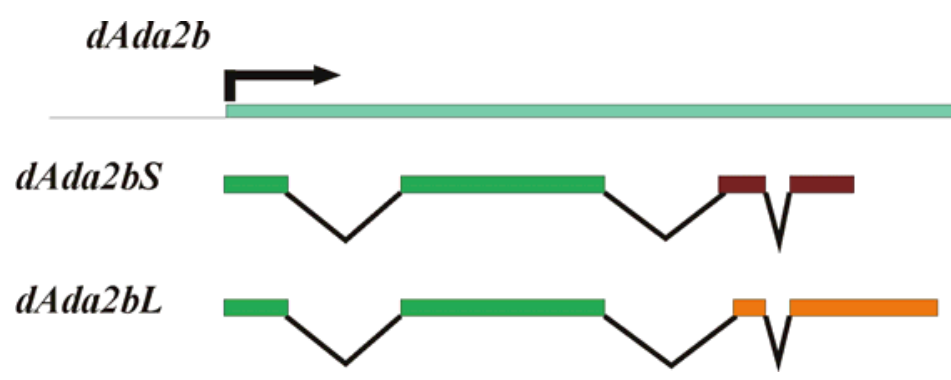

11. ábra: A dAda2b génről képződő transzkriptumok (dAda2bS és dAda2bL) szerkezete Az alternatív splicing során keletkező két transzkriptum első két exonja azonos, míg a 3. és 4. exon az eltérö leolvasási keretből kifolyólag jelentősen különbözik egymástól.

A szekvencia adatok alapján a rövidebb dAda2bS mRNS-ről egy 48,3 kDa molekulasúlyú fehérje, míg a hosszabb dAda2bL izoformáról egy $62 \mathrm{kDa}$ méretű fehérje termelődik. Drosophila embrióban az dADA2b izoformák jelenlétét csoportunknak korábban már sikerült kimutatnia [58]. A két dADA2b fehérje izoformák N-terminális 330 aminosavas régiója azonos, csak a C-terminális szakaszon különböznek egymástól. Mindkét variáns az Nterminális régió területén tartalmaz egy-egy, az ADA2 fehérjékre jellemző ZZ cink-ujj és SANT domént (12. ábra) [58]. Mind az élesztő ADA2, mind a humán ADA2b fehérje esetében ez a konzervált N-terminális régió elegendő a GCN5 fehérjével történő összekapcsolódáshoz [43] [74]. Az ADA2 fehérjékre jellemző SANT domén hozzájárul a SAGA komplex megfelelő szubsztrát felismeréséhez és katalitikus aktivitásához, mivel a SANT domén módosítás nélküli nukleoszómákhoz képes kötődni [26] [56]. A SANT domén mögött elhelyezkedő ADA2 régió felelős a katalitikus HAT modul felépülése során az ADA2-ADA3 interakció kialakításáért [43] [74]. Az ADA2 fehérjék C-terminális régiója több, konzervált szerkezetü $\alpha$-helikális motívumot tartalmaz. Az egyik ilyen motívum a kromatinszerkezetet módosító fehérjékhez köthető, négy $\alpha$-helixből felépülő SWIRM domén. A legtöbb ADA2 fehérjében megtalálható ilyen SWIRM domén, viszont mindkét Drosophila dADA2b izoformából hiányzik [75] [76].

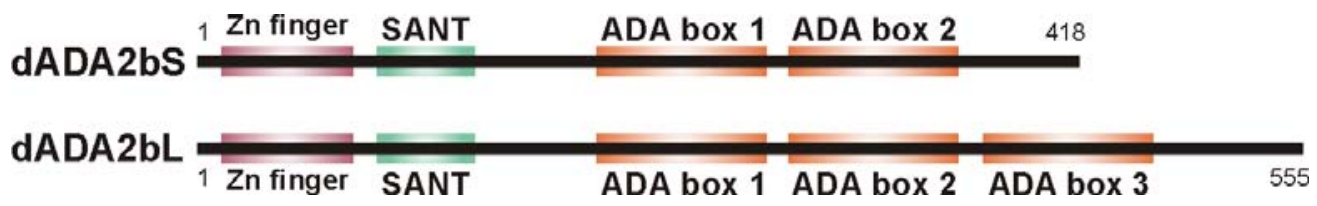

12. ábra: A rövid és hosszú dADA2b izoform domén szerkezete

Mindkét dADA2b izoformában megtalálható az N-terminális régióban elhelyezkedő ZZ cinkujj (Zn finger) motívum és SANT domén. A C-terminális részen a rövidebb dADA2bS izoformából hiányzik a harmadik ADA motívum (ADA boksz 3). 
A másik konzervált motívum az ADA2 fehérjékre jellemző, ( $\alpha$-hélix) $)_{1}-(\text { loop })_{1}-(\alpha-$ hélix) $)_{2}$-(loop) $)_{2}$-( $\alpha$-hélix $)_{3}$ mintázatot hordozó ADA motívum. A két dADA2b izoforma közül a rövidebb variáns csak két, míg a hosszabb három darab ilyen ADA motívumot tartalmaz a C-terminális régióban [58]. Ezek az ADA motívumok a histone-fold doménekhez hasonló szerkezeti elemeket tartalmaznak, amelyek nemcsak hiszton fehérjékben, hanem különböző adaptor és koaktivátor komplexek (TFIID, SAGA) alegységeiben is előfordulnak [57]. Feltételezhetően ezeknek az ADA motívumoknak az ADA2 fehérjék a komplex más alegységeivel kialakított kölcsönhatásainak létrejöttében lehet fontos szerepe. 


\section{Célkitüzések}

Dolgozatomban a dSAGA specifikus hiszton acetilációnak a génmüködés szabályozásában betöltött szerepét tárgyalom. Ehhez a következő kérdéseket fogom áttekinteni:

2.1 Késői L3 lárva és korai báb állapotban mely gének expresszióját szabályozza a dSAGA specifikus acetiláció?

- dAda2b mutáns egyedek teljes transzkriptum analízise késői L3 lárva és korai báb állapotban

2.2 A dSAGA komplexre specifikus dADA2b alegység két izoformája hogyan járul hozzá a dSAGA génmüködés szabályozásában betöltött funkciójához?

- A dADA2b izoformák expressziójának, valamint a dADA2b rövid izoforma funkciójának vizsgálata

2.3 A dSAGA komplex és az általa létrehozott H3K9 acetiláció közvetlenül befolyásolja-e a 2.1-es pont alapján dSAGA-függő transzkripciót mutató gének expresszióját?

- A dADA2b fehérje kötődésének, valamint a dSAGA specifikus H3K9 acetiláció szintjének meghatározása dSAGA-függő és dSAGA-független transzkripciójú gének különböző régióin

\subsection{A dSAGA specifikus H3K9 acetiláció miként befolyásolja a génaktiváció} folyamatát?

- A dSAGA specifikus H3K9 acetilációs mintázat és ennek transzkripcióra kifejtett hatásának feltérképezése az Eip74EF és Eip75B ekdizon indukált gének aktivációja során 


\section{$\underline{\text { 3. Felhasznált anyagok és módszerek }}$}

\subsection{Felhasznált Drosophila melanogaster törzsek, keresztezések}

A használt Drosophila törzseket standard táptalajon (9,3 g agar, 61,2 g kukoricadara, 129,4 g glükóz, 32,4 g száraz élesztő, $10 \mathrm{ml} 10 \%$ Nipagin), $25{ }^{\circ} \mathrm{C}$-on tartottam fenn. A kísérletekben $w^{1118}$ törzset használtam vad típusú kontrollként.

A $d A d a 2 b^{842}$ deléciós allél a $d A d a 2 b$ gén 800 bp hosszúságú, P-elem mobilizációval létrehozott deléciós null mutánsa. A deléció szabályozó régiókon kívül az első exon és az első intron régióját is érinti és mind a két dADA2b izoforma termelődését megszünteti. A homozigóta mutánsok esetében már a késői (15.) embrionális stádiumban nincs jelen kimutatható anyai hatású dADA2b fehérje, a deléció mégis csak a késői báb (P5) és pharate adult stádiumban okoz letalitást [72] [73].

A dADA2b izoformák vizsgálatára a laborunkban korábban előállított transzgenikus Drosophila törzseket használtuk. A dADA2bS izoforma esetén kétféle törzset használtunk (13. ábra). Az egyik a dAda2bS-EGFP dAda2 $b^{842}$ törzs, amely a rövid izoformának megfelelő genomikus szekvenciát az EGFP-vel C-terminális fúzióban termelő transzgént tartalmazza. Ez a transzgén $d A d a 2 b$ deléciós háttéren, egy 600 bp hosszúságú $d A d a 2 b$ promóter szabályozása alatt müködik. Ezt a 600 bp-os szakaszt egy teljes értékü dAda2b promoternek tekinthetjük, mivel korábbi kísérletekben ezen régió irányítása alatt kifejeződő $d A d a 2 b$ genomi transzgén a $d A d a 2 b$ deléciós egyedekre jellemző bábletális fenotípust teljes mértékben menekítette [72]. A másik az UAS-Gal4 rendszer segítségével a rövid izoforma túltermelését biztosító törzs, amely, a rövid izoformát kódoló cDNS-t tartalmazó UAS-dAda2bS transzgént $d A d a 2 b^{842}$ deléciós háttéren hordozza. Ezen konstrukció kifejeztetéséhez az általános expressziót biztosító daughterless(da)-Gal4 driver törzset alkalmaztuk. A dADA2bL izoforma vizsgálatához a $d A d a 2 b L-E G F P d A d a 2 b^{842}$ konstrukciót tartalmazó törzset használtuk. Mivel ez a transzgén C-terminális EGFP fúzióval a hosszú izoformának megfelelő genomikus szekvenciát tartalmazza, az EGFP fehérjével jelölt dADA2bL izoforma mellett alternatív splicing útján a dADA2bS izoforma kifejeződését is biztosítja. Ez a transzgén dAda2b deléciós háttéren, a 600 bp hosszúságú dAda2b promóter szabályozása alatt expresszálódik. 


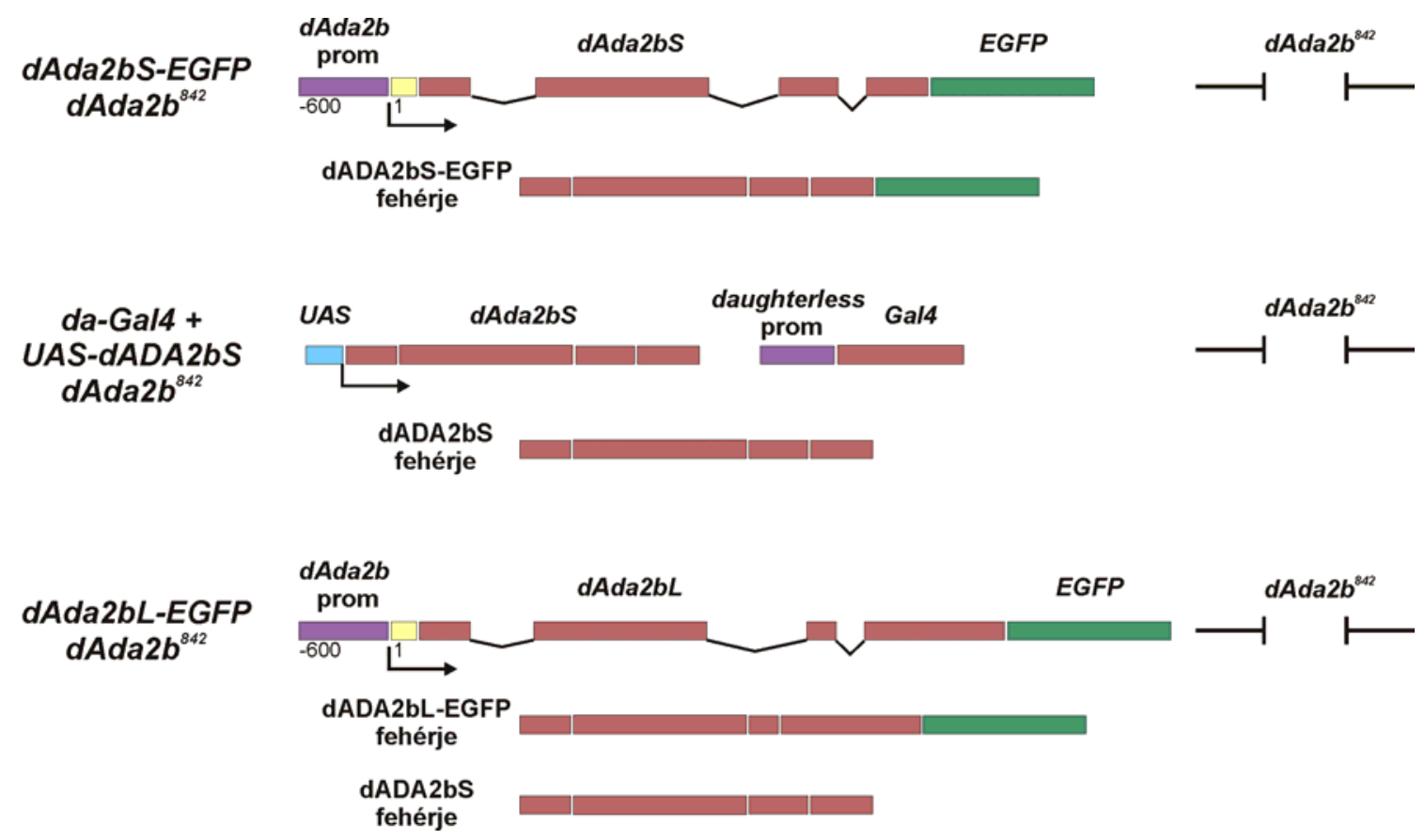

13. ábra: A dADA2b izoformák vizsgálatára használt transzgenikus törzsek jellemzése Az ábra a használt Drosophila törzsek által hordozott transzgének felépítését valamint az azokról termelődő fehérjék szerkezetét mutatja.

\subsection{Drosophila mintagyüjtés}

Western blot analízishez: $w^{1118}$ embrionális, lárva, báb és imágó, valamint $d A d a 2 b^{842} / d A d a 2 b^{842}$ homozigóta, dAda2bS-EGFP/dAda2bS-EGFP; dAda2b $b^{842} / d A d a 2 b^{842}$, Da-Gal4 dAda2b $b^{842} / U A S-d A d a 2 b S$ dAda2 $b^{842}$, és dAda2bL-EGFP dAda2b $b^{842} / d A d a 2 b L-E G F P$ $d A d a 2 b^{842}$ L3 lárva és késői báb fejlődési állapotú Drosophila mintákat gyüjtöttünk.

Nyálmirígy óriáskromoszómák immunfestéséhez: $w^{1118}, d A d a 2 b^{842}$ homozigóta, dAda2bSEGFP/dAda2bS-EGF; dAda2b $b^{842} /$ dAda2b $b^{842}$, Da-Gal4 dAda2b $b^{842} / U A S-d A d a 2 b S$ dAda2b $b^{842}$, és dAda2bL-EGFP dAda2 $b^{842} / d A d a 2 b L-E G F P \quad d A d a 2 b^{842}$ vándorló L3 lárva stádiumú mintákat gyüjtöttünk össze nyálmirígy preparáláshoz.

DNS microarray: az analízishez anterior spirákulumukat kitürt (SpEv) $w^{1118}, d A d a 2 b^{842}$, valamint dAda2bS-EGFP/dAda2bS-EGF; dAda $b^{842} / d A d a 2 b^{842}$ homozigóta L3 lárvákat gyüjtöttünk. A P3 báb minták legyüjtéséhez $w^{1118}$ és $d A d a 2 b^{842}$ mutáns lárvákat azonos fejlődési állapotra szinkronizáltuk. Ehhez fehér báb stádiumban lévő állatokat gyüjtöttünk, majd 10 órán keresztül $25{ }^{\circ} \mathrm{C}$-on nedves kamrában tároltuk, végül folyékony nitrogénben lefagyasztottuk őket. Minden genotípusból, mindkét fejlődési állapotban három párhuzamos mintát gyüjtöttünk, egyenként mindegyik 10-10 db lárvát/bábot tartalmazott. 
Apoptózis kimutatásához: $w^{1118}$, dAda2 $b^{842} / d$ Ada2 $b^{842}$ mutáns és da-Gal4 dAda2 $b^{842} / U A S$ dAda2bS dAda2 $b^{842}$ genotípusú, minden genotípusból minimum $15 \mathrm{db}$ vándorló L3 stádiumú lárvát $4000 \mathrm{R}(150 \mathrm{kV}, 0,5-\mathrm{mm}$ Al filter, $1000 \mathrm{R} /$ perc) Röntgen sugárzással kezeltünk.

Kromatin immunprecipitációhoz: 1-1 gram $w^{1118}$ és dAda $2 b^{842} /$ dAda $b^{842}$ homozigóta, anterior spirákulumukat kitürt (SpEv); $w^{1118} 24-28$ órás, vándorló és $\mathrm{SpEv}$ L3-as lárvát, valamint $d A d a 2 b^{842} / T M 6 c$ heterozigóta és $d A d a 2 b^{842} / d A d a 2 b^{842}$ homozigóta vándorló L3 lárvát gyüjtöttünk össze, amelyeket folyékony nitrogénben lefagyasztottunk és $-80{ }^{\circ} \mathrm{C}$-on tároltuk öket.

Génexpressziós mérésekhez: az L3 lárvastádium során 4 órás felbontással $w^{1118}$ lárvákból mintát gyüjtöttünk. Ehhez 4 órás intervallumban L2/L3 lárvaállapot közötti vedlésen átesett lárvákat válogattunk, majd belölük az L3 lárvastádium végéig 4 óránként 5-5 darabot folyékony nitrogénben lefagyasztottunk és az RNS izolálásig $-80^{\circ} \mathrm{C}$-on tartottuk öket. Ehhez hasonlóan 5-5 darab dAda2 $b^{842} / T M 6 c$ heterozigóta és dAda $2 b^{842} / d A d a 2 b^{842}$ homozigóta L3 lárvát az L2/L3 lárvaállapot közötti vedlést követöen 24-28, 40-44 és $46-48$ órával folyékony nitrogénben lefagyasztottunk.

\subsection{Western blot analízisek}

A Drosophila mintákat szonikációs pufferben (50 mM Tris-HCl pH 7,9, 2 mM EDTA pH 8,0, $50 \mathrm{mM} \mathrm{NaCl}, 0,5 \mathrm{mM}$ DTT, $10 \mathrm{mM}$ Na-butirát, 1x PIC) homogenizáltuk, majd azonos mennyiségü 2x SDS loading puffert ( $20 \%$ glicerin, $100 \mathrm{mM}$ Tris- $\mathrm{HCl} \mathrm{pH}$ 6,4, 200 mM DTT, 4\% SDS, 0,2\% brómfenolkék, 5\% $\beta$-merkaptoetanol) adtunk a mintákhoz. Ezután 5 percig $100{ }^{\circ} \mathrm{C}$-on denaturáltuk a fehérjéket, majd a szövettörmelék kiülepítése érdekében lecentrifugáltuk (10 perc, $\left.13000 \mathrm{rpm}, 4{ }^{\circ} \mathrm{C}\right)$ a mintákat. Az elkészített kivonatok fehérjetartalmát Bradford reagenssel (BioRad) határoztuk meg

A fehérjeanalízishez azonos mennyiségü Drosophila mintákat 12\%-os Tris-glicin-SDS PAGE-dzsel elválasztottunk, majd elektroblottolással a $0,45 \mu \mathrm{m}$ pórusméretủ nitrocellulóz membránra rögzítettük. Ezt követően a membránt $5 \%$ tejport tartalmazó TBST oldatban (10 $\mathrm{mM}$ Tris- $\mathrm{HCl} \mathrm{pH}$ 8,0, $150 \mathrm{mM} \mathrm{NaCl}, 0,05 \%$ Tween-20) 2 órán keresztül blokkoltuk. Az immunreakcióhoz az elsődleges ellenanyagot 2\%-os BSA-TBST oldatban hígítottuk, majd a membránt egy éjszakán keresztül $4{ }^{\circ} \mathrm{C}$-on ebben inkubáltuk. A dADA2b fehérje kimutatására nyúlban termeltetett poliklonális ellenanyagot használtunk 1:1000-hez hígitásban. A H3 9-es lizinjén acetilált hisztonok kimutatására az Abcam ab4441 számú nyúl eredetű poliklonális 
ellenanyagot 1:5000-szeres hígításban használtuk. A kötődött elsődleges ellenanyagok kimutatásához 2 órán keresztül $2 \%$ BSA-TBST oldatban 1:10000-szeresére hígított, torma peroxidázzal kapcsolt nyúl IgG ellenes másodlagos ellenanyaggal (Dako, P0448) inkubáltuk a mintákat. Az ellenanyagokkal történt kezeléseket követően háromszor 10 percig TBST oldattal mostuk a membránt. Ezt követöen a membránt Immobilon Western Chemiluminescent HRP Substrate (Millipore) reagenssel inkubáltuk 5 percig szobahőn, majd a keletkezett kemilumineszcens jelet röntgenfilmen rögzítettük.

\section{$\underline{3.4 \text { dAda } 2 b^{842} \text { mutáns Drosophila lárvák transzkriptom vizsgálata DNS microarray }}$ módszerrel}

A dADA2b fehérjék transzkripció szabályozásban betöltött szerepét $w^{1118}$ és $d A d a 2 b^{842}$ mutáns lárvákban két fejlődési állapotban is megvizsgáltuk DNS microarray kísérlettel. A vizsgált két fejlödési állapot a következő volt: a lárvastádium legvége, amikor az L3 stádiumú lárvák anterior spirákuluma megjelenik ( $\mathrm{SpEv})$, valamint a báb állapot egy korai szakasza, amikor a metamorfózis fontos lépései lezajlanak (P3 prepupa). A dSAGA további funkcióinak feltérképezéséhez a $w^{1118}$ és $d A d a 2 b^{842}$ mutáns lárvák mellett dAda2bS-EGFP $d A d a 2 b^{842} \mathrm{SpEv}$ állapotú lárvákon is transzkriptum analízist végeztünk. A mintákból Qiagen RNeasy kittel a gyár által ajánlott protokoll szerint össz-RNS-t tisztítottunk. Az RNS mintákat Christelle Thimbaud (IGBMC) strasbourgi Affymetrix laborjába küldtük. A minta ellenőrzését és a fluoreszcens jelölést ott végezték az Affymetrix labor protokollját követve. A hibridizáció során a lárvamintákhoz a több mint 18500 transzkriptumot reprezentáló GeneChip Drosophila Genome 2.0 Array-t (Affymetrix) használtuk, a bábminták vizsgálatához pedig a több mint 13500 transzkriptumot reprezentáló GeneChip Drosophila Genome Array-t (Affymetrix) alkalmaztuk. A hibridizációt GeneChip Fluidics Station 400 hibridizációs kamrában az EukGE_WS2v4 protokoll szerint végezték, a jel detektálásához Scanner GeneArray 2500 d'Agilent Technologies scannert használtak.

A kiértékelés során csak azokat a géneket vettük bele az analízisbe, amelyek normalizált hibridizációs jele egy adott genotípusból (az adott fejlődési állapotban) származó három biológiai ismétlésből legalább kettő esetében „present” kategóriába esett. Az adatok kiértékelésénél a kapott szignál intenzitások összehasonlításához Student-féle t-tesztet alkalmaztunk, majd az expressziójukban szignifikáns változást mutató gének közül kiválasztottuk a kétszeres expressziós változást mutató gének csoportjait. 
A gén ontológiai (GO) analízis során a GOrilla on-line analízis programmal (http://cbl-gorilla.cs.technion.ac) [77] azonosítottam a microarray adatok között feldúsulást mutató, azaz a véletlenszerű eloszláshoz képest nagyobb arányban reprezentált gén ontológiai csoportokat. A program által felhasznált GO adatbázis 2013. február 9.-én került frissítésre.

Az analízis során a microarray kísérletből származó megnövekedett ill. csökkent expressziót mutató gének listáit a microarray chip-en található összes gén listájával (background set) vetettük össze. A vizsgálatból a duplikált valamint a GO kategóriába nem besorolható gének ki lettek zárva. A bevitt 16088 gén azonosítóból a szoftver 14440-et ismert fel. Ebből 2019 duplikátum el lett távolítva, további 2316-ot az adatbázis alapján nem lehetett GO kategóriákba sorolni; így a felhasznált teljes gén listát 10105 gén alkotta.

A szoftverrel azokat a GO kategóriákat listáztattuk ki, amelyekbe eső gének $\mathrm{P}<0,001$ szignifikancia szinttel jellemezhető feldúsulást mutattak a génexpressziós változásokat mutató adatsorokban. A program által az egyes GO kategóriák feldúsulására számított $\mathrm{P}$ értékek a hipergeometrikus statisztikai modellen alapulnak. A program által számított dúsulási értékek (E, enrichment) a következőképpen lettek kiszámítva: $E=(b / n) /(B / N)$, ahol

b: az adott GO kategóriába eső gének száma a változást mutató gének listájában

n: a gének száma a változást mutató gének listájában

B: az adott GO kategóriába eső gének száma a microarray chipen található gének teljes listájában

$\mathrm{N}$ : a gének száma a microarray chipen található gének teljes listájában.

A kiszámított eredményekből a GOrilla szoftverrel integrált Graphviz eszközzel készítettem ábrákat.

\subsection{Nyálmirigy óriáskromoszóma preparálás és immunfestés}

Az élesztővel dúsított táptalajon növesztett, vándorló L3 lárvák nyálmirigyeit $30 \mu 11 \mathrm{X}$ PBS (137 mM NaCl, 2,7 mM KCl, 8,1 mM Na $\left.2 \mathrm{HPO}_{4}, 1,76 \mathrm{mM} \mathrm{KH}_{2} \mathrm{PO}_{4}, \mathrm{pH} 7,4\right), 0,5 \%$ NP40 oldatban kiboncoltuk. Ezt követően a nyálmirigyeket 40 másodpercig 1X PBS, 2\% NP-40, $3,7 \%$ formaldehid oldatban, majd 40 másodpercig $45 \%$ ecetsav, 3,7\% formaldehid oldatban, végül 1 percig 45\%-os ecetsav oldatban inkubáltuk. A preparátumot szilikonizált fedőlemezzel lefedtük, majd erőteljes nyomással szétroncsoltuk a szöveteket.

$\mathrm{Az}$ immunfestés első lépéseként a preparátumokat 1 órán keresztül $25^{\circ} \mathrm{C}$-on PBST (1X PBS, 0,1\% Tween-20) + 5\% FCS (Foetal Calf Serum) oldatban inkubáltuk. A blokkoló 
oldat eltávolítása után egy éjszakára H3K9ac ellen nyúlban termeltetett poliklonális (Abcam ab4441) ellenanyagot 1:200-szoros hígításban, valamint RNS polimeráz II elleni egér monoklonális ellenanyagot (7G5) 1:250-szeres hígításban, vagy Ser2 és Ser5 aminosavakon foszforilált RNS polimeráz II elleni egér monoklonális (Covance H5) ellenanyagot 1:250szeres hígításban tartalmazó 5\% FCS-PBST oldatba helyeztük a mintákat. Ezután háromszor 5 percig PBST oldattal mostuk a preparátumokat, majd 1 órán keresztül 5\% FCS-PBST oldatban 1:500-szorosára hígított, Alexa Fluor 555 fluoreszcens festékkel kapcsolt, nyúl IgG elleni másodlagos ellenanyaggal (Molecular Probes) valamint Alexa Fluor 488 fluoreszcens festékkel kapcsolt, egér IgG elleni másodlagos ellenanyaggal (Molecular Probes) sötétben inkubáltuk. A továbbiakban ismét három alkalommal 5 percig PBST oldalban mostuk a mintákat, majd 5 percig PBST $+1 \mu \mathrm{g} / \mathrm{ml}$ DAPI oldatban inkubáltuk a preparátumokat. $\mathrm{Az}$ oldat eltávolítása után $10 \mu$ Fluoromount (Sigma) segítségével fedőlemezzel lefedtük a preparátumokat. Az elkészített preparátumokat fluoreszcens mikroszkóppal vizsgáltuk.

\subsection{Apoptózis kimutatása acridine orange festéssel}

A kezelt és a kezeletlen kontrol lárvákat az ionizáló sugárzással történő kezelést követően 4 órával PBS oldatban felboncoltuk. A vizsgálni kívánt imágó korongokat kipreparáltuk, és 5 percre PBS $+1,6 \mu \mathrm{g} / \mathrm{ml}$ acridine orange oldatba helyeztük. Ezután háromszor 5 percig PBS oldattal mostuk a mintákat, majd tárgylemezre helyeztük, és fedölemezzel lefedtük öket. A preparátumokat fluoreszcens mikroszkóp alatt vizsgálva megszámoltuk az apoptotikus sejteket.

\section{$\underline{\text { 3.7 Kromatin immunprecipitáció }}$}

\subsubsection{Kromatin izolálás}

1 gram folyékony nitrogénben lefagyasztott lárvát dörzsmozsárban porrá dörzsöltünk, majd $7 \mathrm{ml}$ Puffer A $(60 \mathrm{mM} \mathrm{KCl}, 15 \mathrm{mM} \mathrm{NaCl}, 15 \mathrm{mM}$ Hepes-KOH pH 7.6, 13mM EDTA, 0,1mM EGTA, 10mM Na-butirát, 0,15mM spermin, 0,5mM spermidin, 0,5\% NP-40, 0,5mM DTT) oldatban felszuszpendáltunk. A szuszpenziót $10 \mathrm{ml}$ térfogató üveg homogenizátorban B típusú pisztulussal tovább homogenizáltunk. A nagyobb szövettörmelékek eltávolításához Miracloth (Calbiochem) szürőn átszürtük a szuszpenziót, majd 2 ml Puffer AS (60mM KCl, 
$15 \mathrm{mM} \mathrm{NaCl}, 15 \mathrm{mM}$ Hepes-KOH pH 7.6, 1mM EDTA, 0,1mM EGTA, 10mM Na-butirát, 0,15mM spermin, 0,5mM spermidin, 0,5mM DTT, 10\% szaharóz) hozzáadása után centrifugálással (3000 rpm 5 perc, $\left.4{ }^{\circ} \mathrm{C}\right)$ kiülepítettük a sejtmagokat. A csapadékot $3 \mathrm{ml}$ Puffer A oldatban felszuszpendáltuk, üveg homogenizátorban A típusú pisztulussal tovább homogenizáltuk, majd $1 \mathrm{ml}$ Puffer AS hozzáadása után újból centrifugálással összegyüjtöttük a sejtmagokat. Ezt a sejtmagi csapadékot Puffer AN (60mM KCl, 15mM NaCl, 15mM Hepes$\mathrm{KOH} \mathrm{pH}$ 7.6, 1mM EDTA, 0,1mM EGTA, 10mM Na-butirát, 0,1\% NP-40) oldatban felszuszpendáltuk és szobahőn 1\% formaldehiddel keresztkötöttük a kromatint. 10 perc elteltével $300 \mu \mathrm{l} 1 \mathrm{M}$ glicin hozzáadásával állítottuk le a keresztkötési reakciót, majd a sejtmagokat kétszer $10 \mathrm{ml}$ AN pufferrel mostuk. Ezután 1,5 ml lízis pufferben (50mM Tris$\mathrm{HCl} \mathrm{pH}$ 8.0, 1\% SDS, 10mM EDTA, 10mM Na-butirát) feltártuk a sejtmagokat, és 4 x 20 másodpercig Diogenode Bioruptor szonikátorral fragmentáltuk a kromatint. A nem fragmentálódott kromatin darabokat centrifugálással eltávolítottuk (14000 rpm 10 perc, $\left.4{ }^{\circ} \mathrm{C}\right)$ és spektrofotométerrel meghatároztuk a kromatin koncentrációját. Folyékony nitrogénben lefagyasztottuk, majd felhasználásig $-80{ }^{\circ} \mathrm{C}$-on tároltuk a kromatint.

\subsubsection{Immunprecipitáció}

Egy immunprecipitációhoz $25 \mu \mathrm{g}$ kromatint használtunk. Ezt először Puffer D (10mM Tris-HCl pH 8.0, 0,5 mM EGTA, 140mM NaCl, 1\% Triton X-100) oldattal ötszörösére, majd RIPA pufferrel (10mM Tris-HCl pH 8.0, 1mM EDTA, 0.5mM EGTA) kétszeresére hígítottuk. Nemspecifikus kötődések kiküszöbölésére a kihígított kromatint $20 \mu 1 /$ minta BSAval $(3 \mu \mathrm{g} / \mu \mathrm{l})$ és hering sperma DNS-sel $(1 \mu \mathrm{g} / \mu \mathrm{l})$ blokkolt Protein A-Sepharose CL-4B (Sigma) gyönggyel $4{ }^{\circ} \mathrm{C}$-on, 2 órán keresztül forgatva elötisztítottuk. Az így előtisztított kromatint $4{ }^{\circ} \mathrm{C}$-on egy éjszakán át inkubáltuk a következő ellenanyagokkal: $\alpha-\mathrm{H} 3$ (1 $\mu \mathrm{g}$, Abcam ab1791), $\alpha$-H3K9ac (4 $\mu$ g, Abcam ab4441), $\alpha$-dAda2b (5 $\mu 1), \alpha$-Pol. II (2,5 $\mu \mathrm{g}, 7 \mathrm{G} 5$ klón). Az ellenanyag nélküli kontroll mintához (NAC - № Antibody Control) is azonos mennyiségű előtisztított kromatint használtunk, és azt teljesen hasonlóan kezeltük, mint az immunprecipitált mintákat. Másnap a csapadék eltávolításához $\left(13000 \mathrm{~g}, 10\right.$ perc, $\left.4{ }^{\circ} \mathrm{C}\right)$ lecentrifugáltuk a mintákat, majd a felülúszóból 4 órán keresztül $4{ }^{\circ} \mathrm{C}$-on blokkolt Protein ASepharose gyöngyökkel kevertettük a kromatin-ellenanyag komplexeket. A NAC minta felülúszóját használtuk a teljes bemért kromatin mennyiséget meghatározó kontroll (TIC Total Input Control) mintaként. A gyöngyöket centrifugálással $\left(2000 \mathrm{rpm}, 2\right.$ perc, $\left.4{ }^{\circ} \mathrm{C}\right)$ összegyüjtöttük, majd 5x 5 percig RIPA pufferrel, 1x 5 percig LiCl (10mM Tris-HCl pH 8.0, 250mM LiCl, 0,5\% NP-40, 0,5\% Na-DOC, 1mM EDTA) pufferrel, 1x 5 percig TE (10mM 
Tris-HCl pH 8.0, 1mM EDTA) pufferrel mostuk, majd a gyöngyöket $50 \mu 1$ TE pufferben felszuszpendáltuk.

\subsubsection{DNS-fehérje keresztkötések megszüntetése és DNS tisztítás}

A keresztkötések megszüntetéséhez egy éjszakán át $65^{\circ} \mathrm{C}$-on, majd $0,5 \%$ SDS és $500 \mu \mathrm{g} / \mu 1$ Proteináz K jelenlétében 3 órán keresztül $50{ }^{\circ} \mathrm{C}$-on tartottuk a mintákat. A DNS-t fenolkloroform extrakcióval kitisztítottuk, $100 \mu \mathrm{g} / \mathrm{ml}$ glikogén jelenlétében etanol segítségével kicsaptuk, majd $50 \mu 110$ mM Tris- $\mathrm{HCl}$ pH 8.0 oldatban felszuszpendáltuk. Az így kapott DNS mintát használtuk templátként a Q-PCR analízissel történő mennyiségi meghatározás során.

\section{$\underline{\text { 3.8 RNS izolálás és egyes szálú cDNS szintézis }}$}

L3 stádiumú Drosophila lárvákból össz-RNS-t TRIzol (Invitrogen) reagenssel izoláltunk a gyártó által mellékelt protokoll szerint, mintánként 5 darab állatot felhasználva. Az RNS koncentrációját NanoDrop (ND-1000 Spectrophotometer) segítségével határoztuk meg. Az esetleges genomi szennyezés eltávolításához a gyártó utasításai szerint RNáz-mentes DNázI enzimmel (Fermentas) kezeltük a mintákat. A DNáz inaktiválásához $3 \mathrm{mM}$ EDTA hozzáadása mellett 10 percig $65^{\circ} \mathrm{C}$-on inkubáltuk a mintákat. Egyes szálú cDNS-t, 1-1 $\mu \mathrm{g}$ össz RNS bemérésével az Applied Biosystems Reverse Transcription Reagents Kittel állítottunk elő a gyártó útmutatása szerint, az alábbi reakció körülményeket alkalmazva: $25^{\circ} \mathrm{C}$ 10 perc, $37^{\circ} \mathrm{C} 60$ perc, $95^{\circ} \mathrm{C} 5$ perc.

\subsection{Kvantitatív real time PCR (Q-PCR)}

A kvantitatív real-time PCR reakciókat ABI 7500 Real Time PCR System (Applied Biosystems) készülékkel végeztük. A keletkező termékek mennyiségi meghatározásához Power SYBR Green PCR Master Mix (Applied Biosystems) reagenst használtunk a következő reakció körülményeket alkalmazva: $95{ }^{\circ} \mathrm{C} 10$ perc; $95{ }^{\circ} \mathrm{C} 15$ másodperc; $60{ }^{\circ} \mathrm{C} 1$ perc (40 ciklus). A reakciók végén olvadási görbe analízist végezve ellenőriztük a keletkező termék minőségét. Kísérletenként két párhuzamos, $25 \mu 1$ reakció térfogatban végzett mérést végeztünk. 
A génexpressziós analíziseknél cDNS mintákból készített kalibrációs egyenes segítségével, abszolút kvantifikálással határoztuk meg az egyes minták cDNS tartalmát. A génexpressziós vizsgálatokat 3-3 függetlenül izolált mintán végeztük el.

A kromatin immunprecipitáció analízise során az egyes immunprecipitációk során kapott DNS mennyiségét a TIC mintákból készített kalibrációs egyenes segítségével határoztuk meg, és TIC\%-ban adtunk meg. Az egyes immunprecipitációkban kapott DNS mennyiséget korrigáltuk a NAC minta DNS tartalmával.

A mérések során a következő primereket használtuk:

\section{Primer neve}

sug prom fwd (-34)

sug prom rev $(+66)$

sug $3^{\prime}$ fwd (+1525)

sug 3' rev $(+1638)$

Fst prom fwd (-59)

Fst prom rev $(+62)$

Fst 3' fwd (+864)

Fst 3' rev (+964)

cnc prom fwd (-80)

cnc prom rev $(+116)$

cnc 3' fwd (+33437)

cnc 3' rev (+33545)

CycB prom fwd (-39)

CycB prom rev $(+101)$

RpS23 prom fwd (-8)

RpS23 prom rev $(+140)$

RpL32 prom fwd (-19)

RpL32 prom rev $(+120)$

Hus1-like prom fwd (-62)

Hus1-like prom rev $(+96)$

Hus1-like 3' fwd (+3527)

Hus1-like 3' rev (+3628)

AttD prom fwd (-62)

AttD prom rev $(+130)$

Intergenic region 1 fwd
Primer szekvenciája

CGCATATTACCCGAACCTCT

GTTGTCTGTGGTGGGTGCT

CTCGCTAAAACCCAAACAGG

GGTGACTCCACGTCCATCTT

GGCAGTGAATGGAAGTGGTT

CCAAGGCAGTGAAGAGGATAA

ACTATCGATTCTTCAGCGGTCTA

GTTACTCGGAAACGCCAAAT

AACCGCAAAAGCACAAAACT

GTGGTGAGCTTGAAAACGTG

TGGAATCAGTGAGCCAGGA

TGTATAGTCGCCGGAAAAGG

TGCGGCTTAAAAGGGAACTA

TGATCGAGTTTTTGCACACG

GCGGTCACACTGAAAACATC

TTCGCTTAATTCGCACAAAA

TTTCACACCACCAGCTTTTTC

CACGGACTAACGCAGTTCAA

TCGTTATCGGTTTTCGATGTC

GCAGCAGTCGCACTTACCTT

GGCCTTCTTTGGAGCACTT

CCACATCCTGTCGTACATCG

AGTTGCGTACTTTTGCGACA

TCATCACCGACCCTTACTCC

TCAAGCCGAACCCTCTAAAAT 
Intergenic region $1 \mathrm{rev}$

Intergenic region 2 fwd

Intergenic region $2 \mathrm{rev}$

Intergenic region 3 fwd

Intergenic region $3 \mathrm{rev}$

Intergenic region 4 fwd

Intergenic region 4 rev

E74int1 fwd

E74int1 rev

E74ex 8 fwd

E74ex8 rev

E75ex8 fwd

E75ex8 rev

E74RB-prom fwd

E74RB-prom rev

E74RA-prom fwd

E74RA-prom rev

E75RC-prom fwd

E75RC-prom rev

E75RC-int 1 fwd

E75RC-int1 rev

E74int5 fwd

E74int5 rev
AACGCCAACAAACAGAAAATG

CCGAACATGAGAGATGGAAAA

AAAGTGCCGACAATGCAGTTA

CAGTTGATGGGATGAATTTGG

TGCCTGTGGTTCTATCCAAAG

GCTGATGCTTCCTGAAATCC

GTTTGGTGTGCTCGTCCTTT

CATACTAGTTGCCGGCGTAT

TTTAGCACTTCCCACTCCTG

TGTCCGCGTTTCATCAAGT

GTTCATGTCCGGCTTGTTCT

CAACTGCACCACCACTTGAC

GCCTTGCACTCGTTCTTCTC

GCCGACTGAACGACTGAATC

GGAAGACGCAGCAGAGAGAG

CAACTAAACGGCGAACAAGC

GCTTGCGCTCTCTACGCTAA

CCGCATAAACGCACAATCAG

GTGGATTGGGCTCTCTCTGG

AACCGAGCAAAAACACCAAG

CGGTTTCCAAGTTCATTGCT

CTGGGCTTTGGATACACACT

GTGAGATGCGAGAGAGAAGC 


\section{Eredmények}

\subsection{A dSAGA specifikus H3K9 és K14 acetiláció szabályozása alatt álló gének}

\section{azonosítása}

A hiperacetilált nukleoszómákat már régóta egy nyitottabb kromatinszerkezettel és aktív transzkripciós állapottal hozzák összefüggésbe, míg a deacetiláció folyamatát a represszált génmüködéshez kötik. Korábban csirke vörösvérsejtekben expresszálódó, és így nagyfokú DNáz érzékenységet mutató globin gén területén kromatin immunprecipitációs (ChIP) kísérletekben acetilált hiszton fehérjék jelenlétét mutatták ki [78], valamint élesztőben a transzkripciósan inaktív genomikus területeken alacsony mértékü hiszton acetilációt figyeltek meg [79]. S. cerevisiae-ből és emlős sejtekből származó adatok is azt igazolják, hogy az aktívan átíródó gének promótereinek területén magas szintü H3K9 és H3K14 acetiláció mutatható ki [80] [81]. Ezekből az adatokból kiindulva megvizsgáltuk, hogy vajon a dSAGA által létrehozott H3K9 és K14 acetiláció is egy, a transzkripció aktiválásával összefüggésbe hozható hiszton módosítás-e, illetve hogy a dSAGA komplex milyen gének működésének a szabályozásában vesz részt.

\subsection{1 dAda2b mutánsok transzkriptum analízise késői L3 lárva és korai báb}

\section{$\underline{\text { állapotban }}$}

Feltérképeztük milyen a génexpressziós mintázat a dSAGA specifikus H3K9 és K14 acetiláció hiányában, amihez DNS microarray technikával teljes transzkriptom analízist végeztünk két fejlődési állapotban dAda2b mutáns és vad típusú egyedekben. A $d A d a 2 b^{842}$ homozigóta null mutánsok a vad típushoz hasonló egyedfejlódést mutatnak az L3-as lárvastádium végéig. A vad típushoz képest 10 órás késéssel bábozódnak be, majd ezt követően 12 órával, közvetlenül az előbáb-báb átmenet után elpusztulnak (P5 báb állapot) (14. ábra). Ahhoz, hogy a génműködés vizsgálata során kizárjuk az eltérő fejlődési állapotból eredő expressziós különbségek zavaró hatását, morfológiailag jól meghatározható, azonos fejlődési állapotban hasonlítottuk össze a mintákat. Mivel a dAda2b mutánsok letális fázisa a korai báb állapotra tehető, feltételezhetjük, hogy a dADA2b fehérjének a metamorfózis ezen korai szakaszában esszenciális szerepe lehet. Ezért a metamorfózis ezen korai szakaszából választottunk ki két fejlődési állapotot, hogy megvizsgáljuk a dSAGA transzkripció 
szabályozásában betöltött szerepét. Az első állapotnak az L3-as lárva stádium legvégét jelöltük ki, azt az időszakot, amikor a lárva előbábbá alakul át. Ez egy rövid, mintegy 30 perces állapot, amelyet morfológiailag az anterior spirákulumok megjelenése jellemez (SpEv). A második vizsgálati pontnak közvetlenül a dAda2b mutáns letális fázisa előtti időszakot - a 10. órás báb állapotot (10 h báb) - választottuk, amely a jól meghatározható SpEv állapot után 10 órával van.

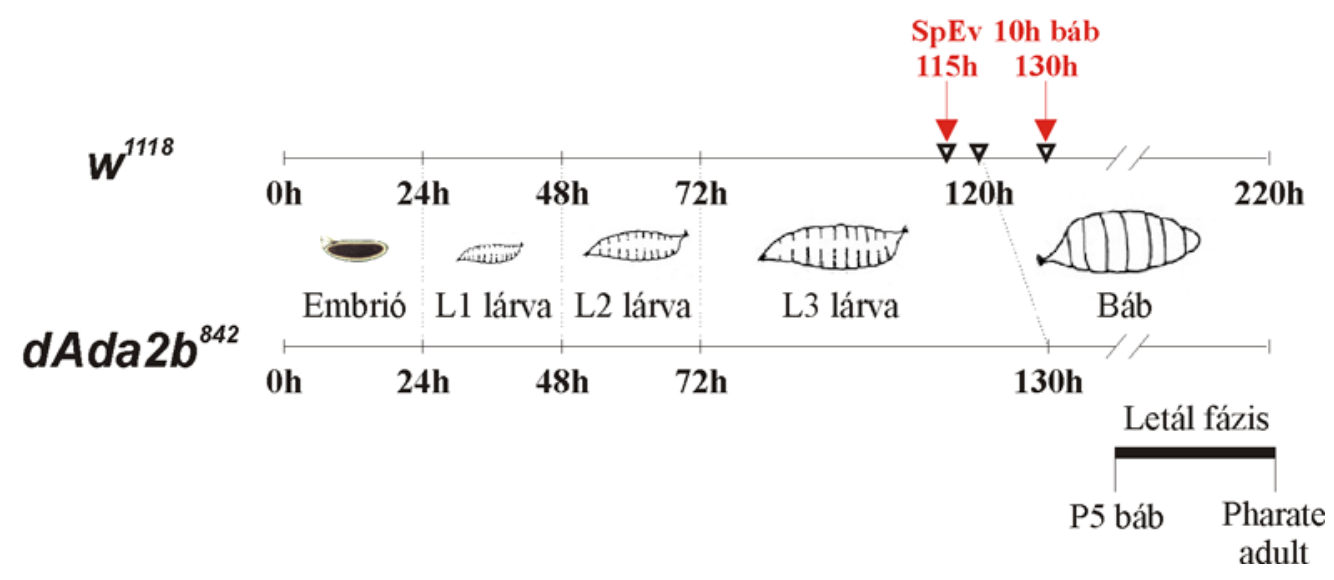

14. ábra: $w^{1118}$ és $d A d a 2 b^{842}$ mutánsok egyedfejlődésének sematikus rajza

Az ábrán a $w^{1118}$ és dAda2b mutáns Drosophlia egyedfejlődésének időbeli összehasonlítása, a transzkriptum analízishez kiválasztott fejlödési állapotok ( $\mathrm{SpEv}, 10 \mathrm{~h}$ báb), illetve a $d A d a 2 b^{842}$ mutánsok letál fázisa látható.

A transzkriptum analízishez kiválasztott fejlődési állapotokban western blot analízissel összehasonlítottuk a dAda2b mutáns és a vad típusban a H3K9 acetiláció mennyiségét (15. ábra). Vad típusban összehasonlítva a két vizsgált fejlődési állapotban a H3K9 acetiláció mennyiségét, az L3 állapothoz képest a báb állapotra jelentősen megemelkedett az acetiláció szintje. A dADA2b fehérje hiányában mind a késői L3 lárvális, mind a korai báb állapot során jelentősen lecsökkent a 9-es lizinen acetilált H3 hisztonok mennyisége. Ezek alapján tehát mindkét stádium alkalmas lehet a dSAGA specifikus H3K9 acetiláció génmüködés szabályozásra kifejtett szerepének vizsgálatára.

Vad típusú és $d A d a 2 b$ egyedekből mind a két fejlődési állapotban (SpEv és 10 h báb) mRNS mintát izoláltunk, amit Christelle Thimbaud (IGBMC) strasbourgi Affymetrix laborjában fluoreszcens festékkel jelöltek, és a teljes Drosophila genomot reprezentáló cDNS microarrayhez hibridizáltak. Az analízis során t-teszt segítségével azonosítottuk azokat a géneket, amelyek expressziója a $d A D A 2 b$ mutáns esetében a vad típushoz képest szignifikáns eltérést mutatott. Ezek közül a minimum kétszeres expresszió-emelkedést, illetve expressziócsökkenést mutató géneket tekintettük dADA2b-függő expressziót mutató géneknek. 


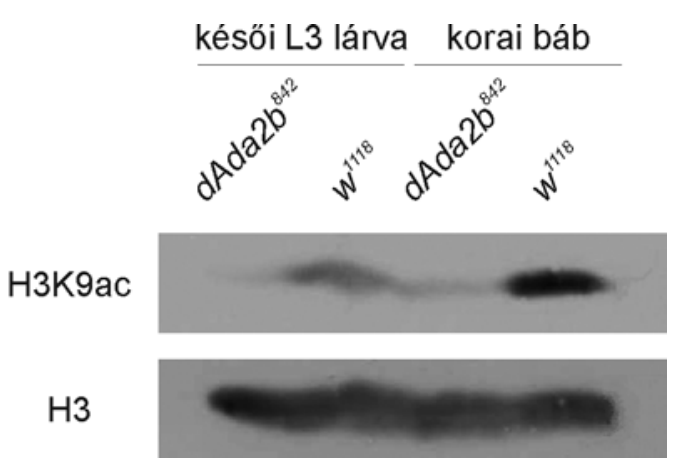

15. ábra: A dADA2b fehérje hiányában mind a késői lárvális, mind a korai báb állapotban csökkent mértékü $\mathrm{H3K9}$ acetiláció jellemző

Az ábrán vad típusú és $d A d a 2 b$ mutáns késői L3 lárvákból, valamint korai bábokból készült fehérjemintákon H3K9ac és H3 specifikus ellenanyaggal készült western blot kísérlet eredménye látható.

\subsubsection{A dADA2b hiányában a vad típustól eltérō expressziót mutató gének} számának meghatározása

A fent említett paraméterek esetén a dADA2b fehérjék hiányában mindkét vizsgált fejlödési állapotban a gének kevesebb, mint 5\%-a mutatott eltérő expressziós szintet (16. ábra). Az acetiláció szerepéről eddig kialakított képnek megfelelően a $d A d a 2 b^{842}$ mutáció jelenlétében a lárvastádium végén (SpEv) 239, a báb állapotban (10 h báb) 437 gén mutatott csökkent mértékü expressziót. Viszont közel azonos számú gén esetében (334 és 466 db) legalább kétszeresen megemelkedett expressziót tapasztaltunk a dSAGA specifikus acetiláció hiányában. A dADA2b fehérjék hiányában mind a csökkent, mind az emelkedett transzkripciót mutató gének esetében csekély az átfedés a két vizsgált fejlődési állapot között, vagyis a lárvastádium végén változást mutató géneknek csak a $10 \%$-a mutat a korai bábstádium során is a vad típustól eltérő expressziót.

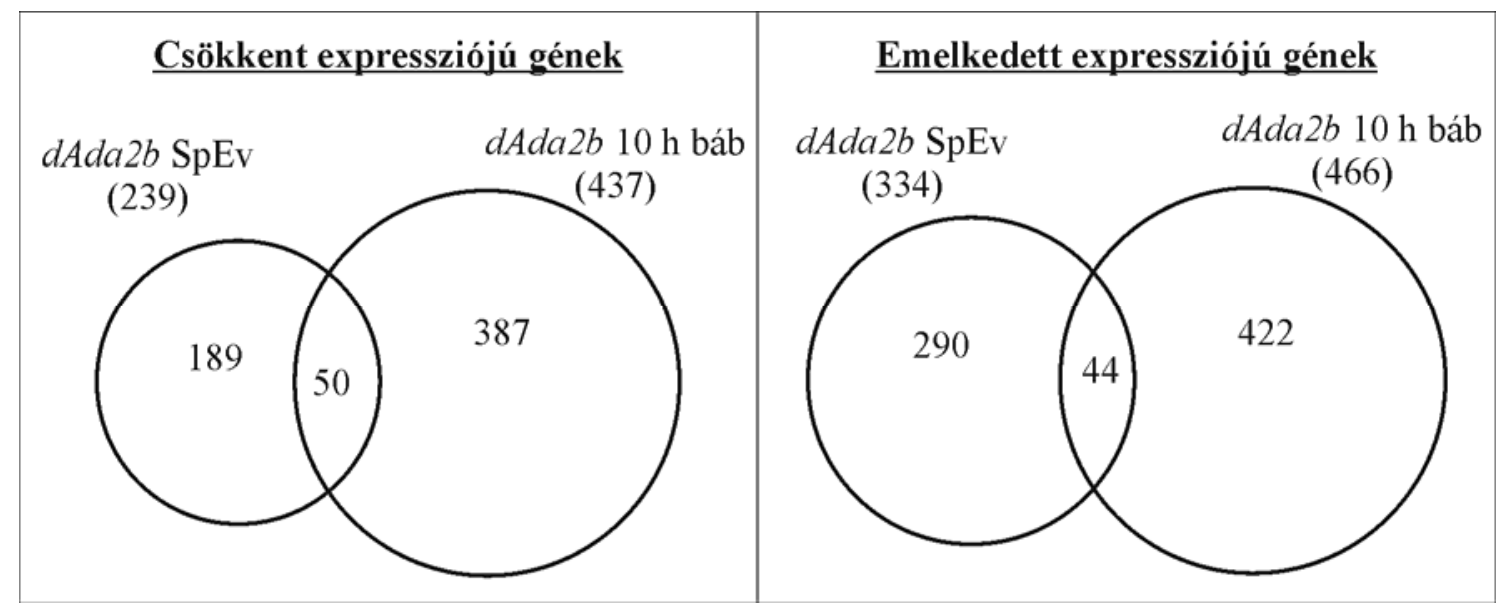

16. ábra: A dAda2b mutánsokban késői L3 lárva ( $\mathrm{SpEv)}$ és báb (10 h báb) állapot során a vad típustól eltérően expresszálódó gének száma látható 


\subsection{3 dADA2b-függő expressziót mutató gének funkcionális csoportosítása}

Bár mind a késői lárva, mind a korai báb állapotban a dADA2b-függő expressziót mutató gének száma alacsony, mindkét fejlődési állapotban hasonló funkcióval rendelkező gének mutattak a vad típusban mérttől eltérő transzkripciós szintet (17. ábra). Ezen funkció szerinti csoportosítás alapján elsősorban kutikula szintézisért felelős gének, néhány ekdizon indukált gén, valamint számos, az immunfunkcióban szerepet játszó fehérje génje mutatott jelentős mértékü dADA2b függést.

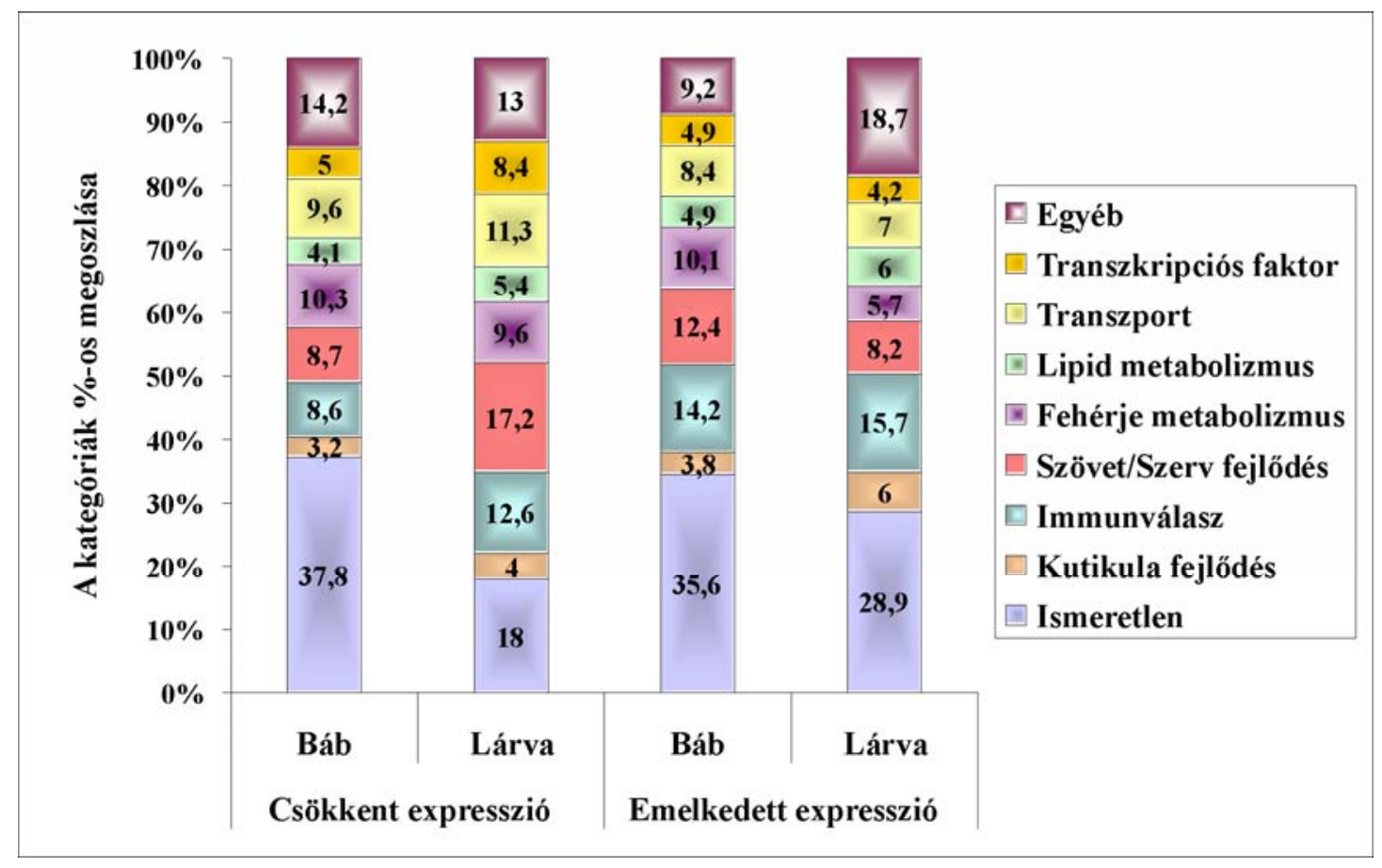

17. ábra: A dADA2b-függő transzkripciót mutató gének funkció szerinti csoportosítása a késői lárva, illetve a korai báb stádium során

GOrilla program segítségével meghatároztuk, hogy a dADA2b-függő expressziójú gének között milyen génontológiai (GO) csoportokba eső gének mutatnak szignifikáns felhalmozódást. A különböző biológiai folyamatoknak (biological process) megfelelő génontológiai csoportok közül a $\mathrm{SpEv}$ és a $10 \mathrm{~h}$ báb állapot során is a biokémiai metabolikus folyamatok, valamint a SpEv állapotban a gamma-sugárzásra indukálódó fehérjék csoportjaiba tartozó gének mutattak csökkent mértékű expressziót (2. táblázat, Függelék F1. és F2. ábra). A dADA2b hiányában az emelkedett expressziót mutató gének egy része metobolikus és proteolítikus folyamatoknak megfelelő génontológiai csoportokba sorolható (3. táblázat, Függelék F3. és F4. ábra). 


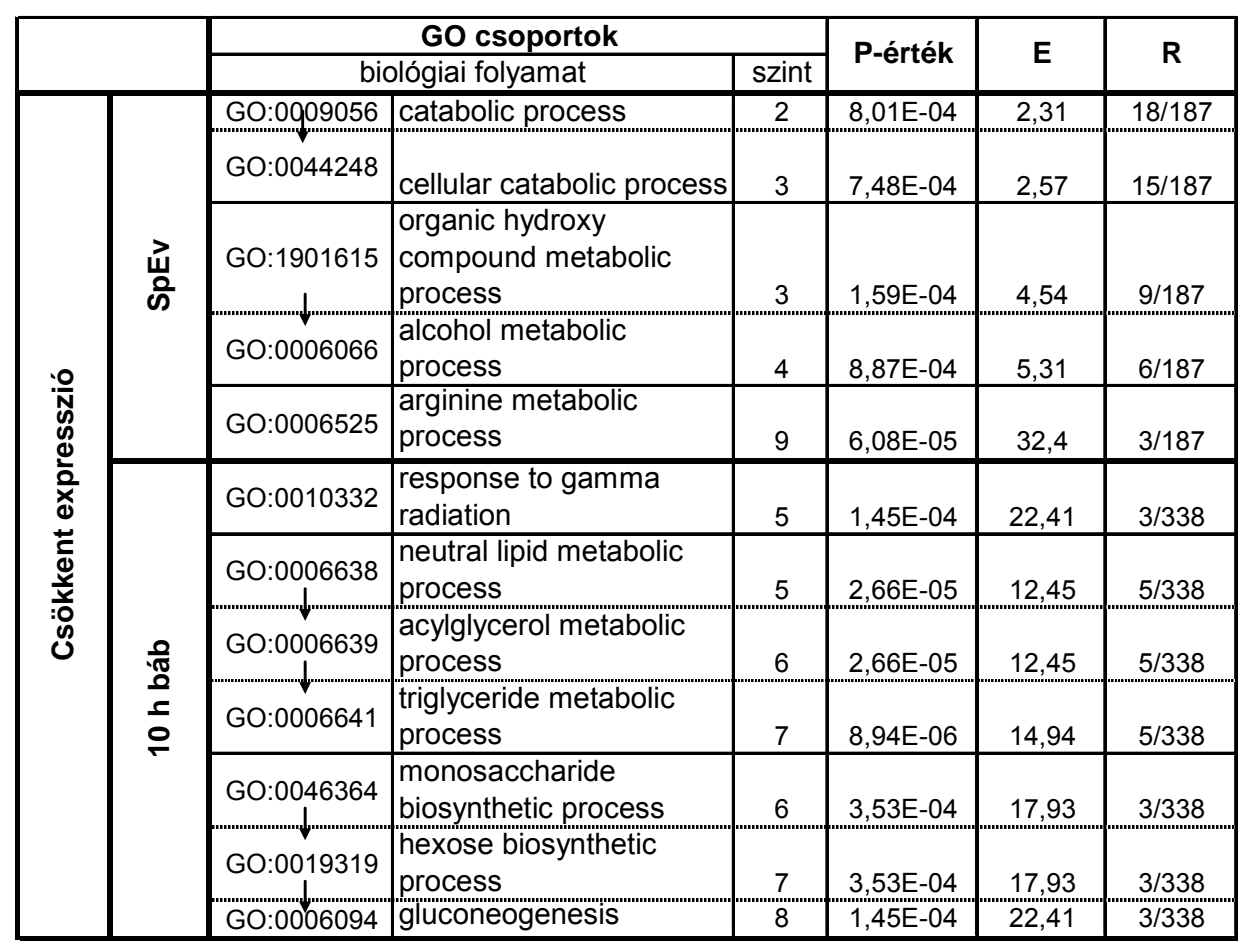

\section{2. táblázat: A dAda2b mutánsban csökkent expressziót mutató gének között azonosítható, szignifikánsan felülreprezentált biológiai folyamatoknak megfelelö génontológiai csoportok}

A táblázatban az látható, hogy a viszgált fejlödési állapotokban ( $\mathrm{SpEv}$ és $10 \mathrm{~h}$ báb) a dAda2b mutánsban csökkent expressziót mutató gének mely biológiai folyamatnak megfelelő génontológiai $(\mathrm{GO})$ csoportokban mutatnak szignifikáns feldúsulást. A nyilak a hierarchiában egymás alatt elhelyezedő $\mathrm{GO}$ csoportokat jelölik. A táblázatban csak a $\mathrm{P}<0,001$ szignifikancia szintnek megfelelő csoportok vannak feltüntetve.

$\mathrm{E}($ Enrichment $)=($ adott GO csoportba esö, csökkent expressziót mutató gének száma / csökkent expressziót mutató gének száma) / (a microarray-en található, adott GO csoportba tartozó gének száma / a microarray-en található összes Drosophila gén)

$\mathrm{R}($ Ratio $)=$ adott GO csoportba eső, csökkent expressziót mutató gének száma / az összes csökkent expressziót mutató gének száma

Főként a korai bábállapotban az emelkedett expressziójú gének egy jelentős része az immunfunkcióval kapcsolatba hozható génontológiai csoportokba sorolható. Ezek között nagy számban megtalálhatóak például az antimikrobiális humorális immunválaszt megvalósító, a Gram-negatív és Gram-pozitív baktériumok, valamint a gombák elleni immunvédekezést megvalósító fehérjék génjei. 


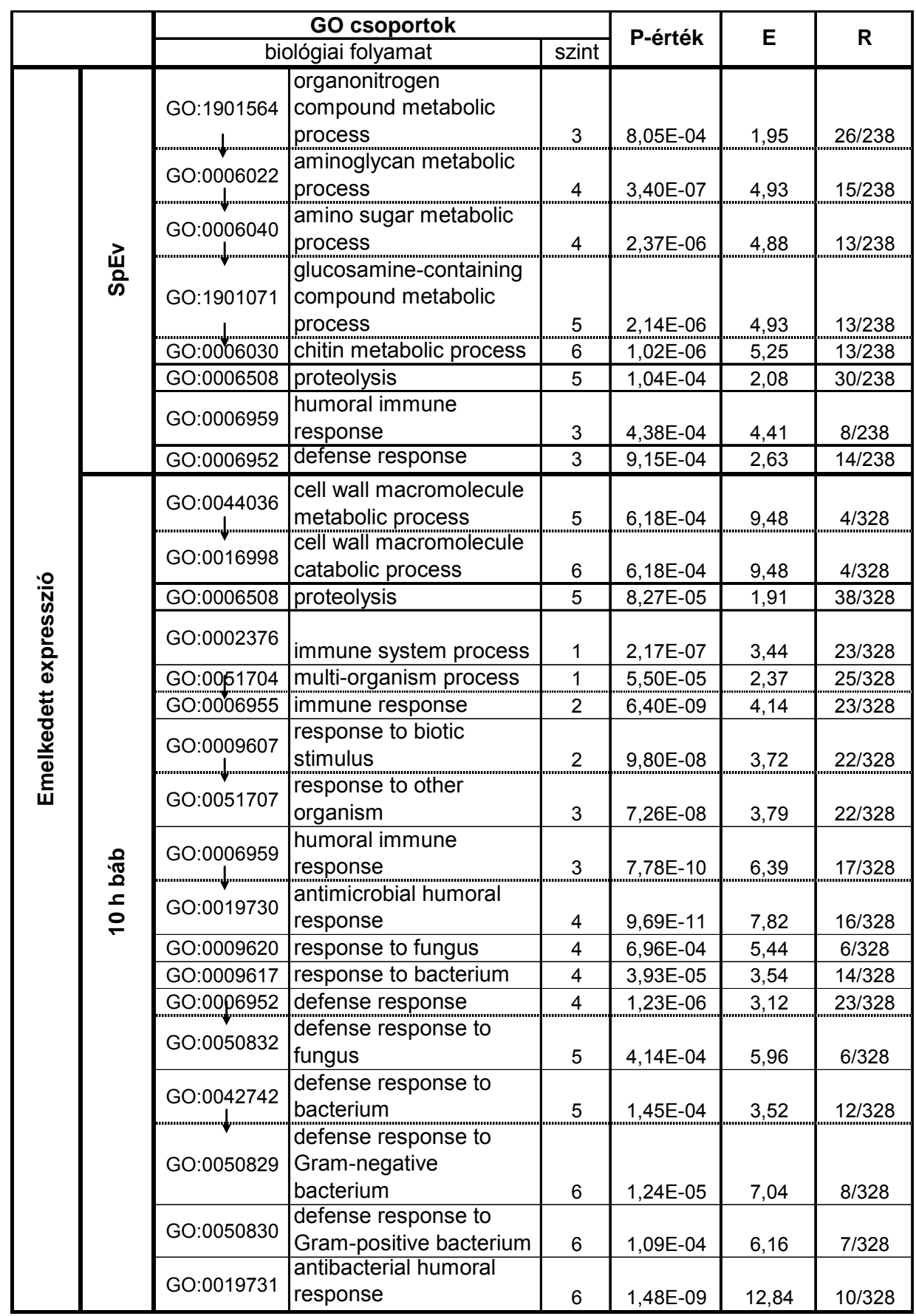

3. táblázat: A dAda2b mutánsban emelkedett expressziót mutató gének között azonosítható, szignifikánsan felülreprezentált biológiai folyamatoknak megfelelö génontológiai csoportok

A táblázatban az látható, hogy a viszgált fejlödési állapotokban ( $\mathrm{SpEv}$ és $10 \mathrm{~h}$ báb) a dAda2b mutánsban emelkedett expressziót mutató gének mely biológiai folyamatnak megfelelö génontológiai (GO) csoportokban mutatnak szignifikáns feldúsulást. A nyilak a hierarchiában egymás alatt elhelyezedő GO csoportokat jelölik. A táblázatban csak a $\mathrm{P}<0,001$ szignifikancia szintnek megfelelő csoportok vannak feltüntetve.

$\mathrm{E}($ Enrichment $)=($ adott GO csoportba eső, emelkedett expressziót mutató gének száma / emelkedett expressziót mutató gének száma) / (a microarray-en található adott GO csoportba tartozó gének száma / a microarray-en található összes Drosophila gén)

$\mathrm{R}$ (Ratio) = adott GO csoportba eső, emelkedett expressziót mutató gének száma / az összes emelkedett expressziót mutató gének száma 


\subsection{A dSAGA komplexre specifikus dADA2b alegység két izoformájának a dSAGA müködésében betöltött funkciója}

Az acetiláció szerepéről eddig kialakított képtől eltérően a transzkriptum analízis során a dSAGA specifikus H3K9 acetiláció hiányában nemcsak csökkent, hanem emelkedett transzkripciót mutató géneket is azonosítottunk. Felvetődik a kérdés, hogy a kapott, ellentétes irányú transzkripciós változások hátterében esetleg a dSAGA komplex heterogenitása áll-e, vagyis hogy a dSAGA komplex esetleg többféle dADA2b alegység összetétellel is előfordulhat, amelyek esetleg más-más folyamatok szabályozásában vehetnek részt.

\subsubsection{A dADA2b izoformák expressziójának vizsgálata}

Megvizsgáltuk, hogy a különböző dADA2b fehérjék az egyedfejlődés különböző szakaszaiban milyen mennyiségben termelődnek, valamint hogy milyen sejten belüli elhelyezkedést mutatnak. A dADA2b fehérjék közös, N-terminális régiója ellen termeltetett anti-dADA2b ellenanyag segítségével $w^{1118}$ genotípusú, különböző egyedfejlődési állapotú állatokon elvégzett western blot analízissel megvizsgáltuk a két fehérje expressziós mintázatát. Részletes felbontásban meghatároztuk az embrionális állapotban, a három (L1, L2, korai L3) lárva stádiumban, majd a báb állapot során - különös tekintettel a korai báb állapotra - valamint közvetlenül a bábból való kikelés előtt álló és kifejlett egyedekben is a dADA2b fehérjék szintjét (18. ábra).

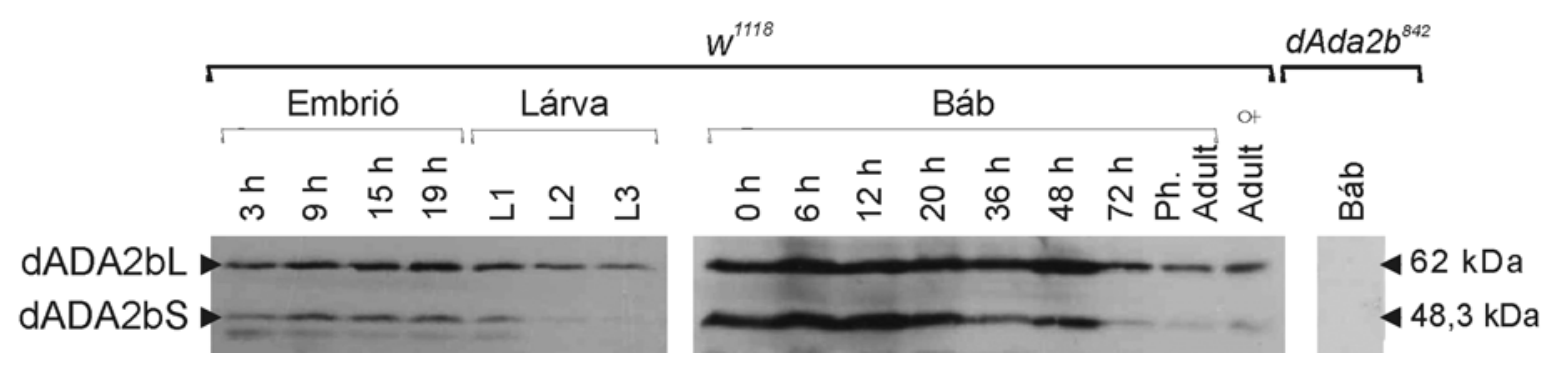

18. ábra: Az ADA2bS és ADA2bL fehérjék expressziója az egyedfejlódés során az embrionális élet végén és a báb állapot kezdetén a legerősebb

Az ábrán a jelölt fejlödési állapotban vad típusú $\left(w^{1118}\right)$ egyedeken dADA2b specifikus ellenanyaggal elvégzett western blot analízis eredménye látható. 
Azt tapasztaltuk, hogy mindkét dADA2b izoforma az egyedfejlődés minden vizsgált szakaszában jelen van, legnagyobb mennyiségben a korai báb állapotban, valamint az embrionális élet során fejeződnek ki. A dADA2bS fehérje szintje az L2, korai L3 stádiumban és a kifejlett egyedekben a dADA2bL-hez viszonyítva rendkívül alacsony, így a rövid izoforma mennyisége az egyedfejlődés során egy sokkal nagyobb mértékü ingadozást mutat, mint amit a dADA2bL esetében láthatunk.

A dADA2b szöveti expressziójának, illetve sejten belüli elhelyezkedésének in vivo vizsgálatához a laborunkban korábban elkészített, zöld fluoreszcens (EGFP) fehérjével jelölt $\mathrm{dADA} 2 \mathrm{bS}$, illetve $\mathrm{dADA} 2 \mathrm{bL}$ izoformát a $d A d a 2 b$ promóter irányítása alatt termelő transzgenikus Drosophila törzseket használtuk (dAda2bS-EGFP és dAda2bL-EGFP). Fluoreszcens mikroszkópiával késői L3 lárvák nyálmirigyeiben megvizsgálva az izoformák sejten belüli lokalizációját megállapítottuk, hogy mindkét dADA2b fehérje a sejtmagban található (19. ábra).

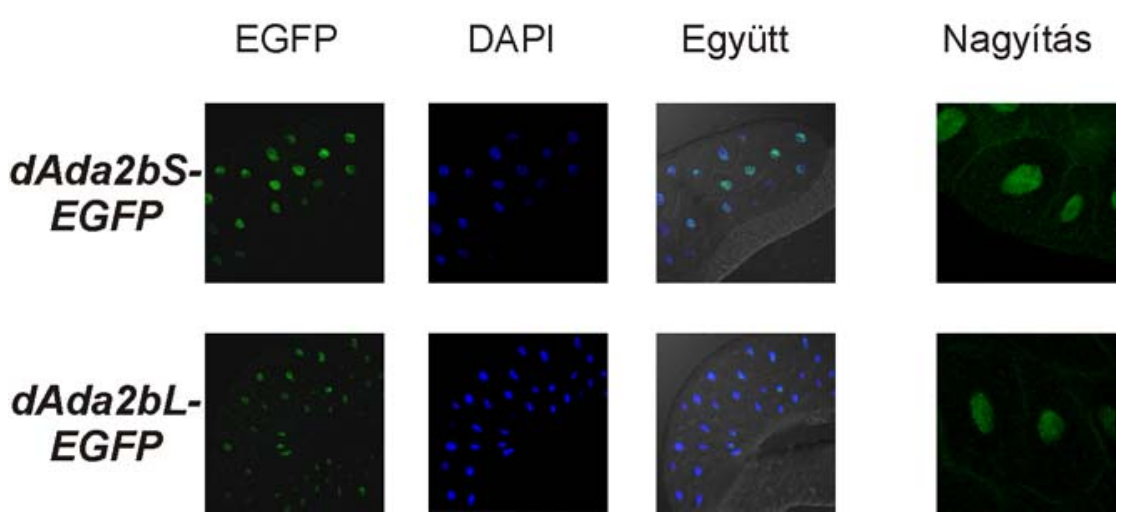

19. ábra: A dADA2bS-EGFP és dADA2bL-EGFP fehérjék expressziója

Az ábrán késői L3 lárvák nyálmirigyeiben az EGFP-vel jelölt dADA2b izoformák sejten belüli lokalizációja látható.

Tehát két eltérő módszerrel is azt az eredményt kaptuk, hogy a dADA2b fehérjék expressziója a metamorfózis kezdetén a legmagasabb, ami összhangban van azzal a megfigyeléssel, hogy a $d A d a 2 b$ gén müködését megszüntető mutáció $\left(d A d a 2 b^{842}\right.$ ) is a báb fejlődésének korai szakaszában, 12 órával az előbáb kialakulása után okoz letalitást [72]. 


\subsubsection{A dADA2b rövid izoforma funkcionális vizsgálata}

Korábbi kísérletek azt mutatták, hogy a $d A d a 2 b^{842}$ deléció hatását a teljes $d A d a 2 b$ gén visszajuttatása képes komplementálni [72]. Mivel erről a genomi régióról mindkét dADA2b izoforma termelődik, felvetődött az a kérdés, vajon a harmadik ADA motívumot nem tartalmazó, rövidebb dADA2b izoforma önmagában képes-e ellátni a teljes dADA2b funkciót.

\subsubsection{A dADA2b izoformák vizsgálatához használt transzgenikus törzsek jellemzése}

A dADA2bS fehérje funkcionális vizsgálatához kétféle transzgenikus Drosophila törzset használtunk: egyrészt a $d A d a 2 b$ saját promóterének szabályozása alatt álló, a dAda2b endogén expressziójához hasonló kifejeződést biztosító transzgént (dAda2bS-EGFP konstrukció) hordozó törzset; másrészt az UAS-dAda2bS transzgenikus konstrukcióról daugterless(da)-GAL4 driver segítségével túltermelő törzset (13. ábra). Kontrollként a dAda2bL-EGFP konstrukciót hordozó törzseket használtunk, ahol a dAda2b promóter irányítása alatt termelődik a rövid, valamint az EGFP fehérjével jelölt hosszú izoforma is.

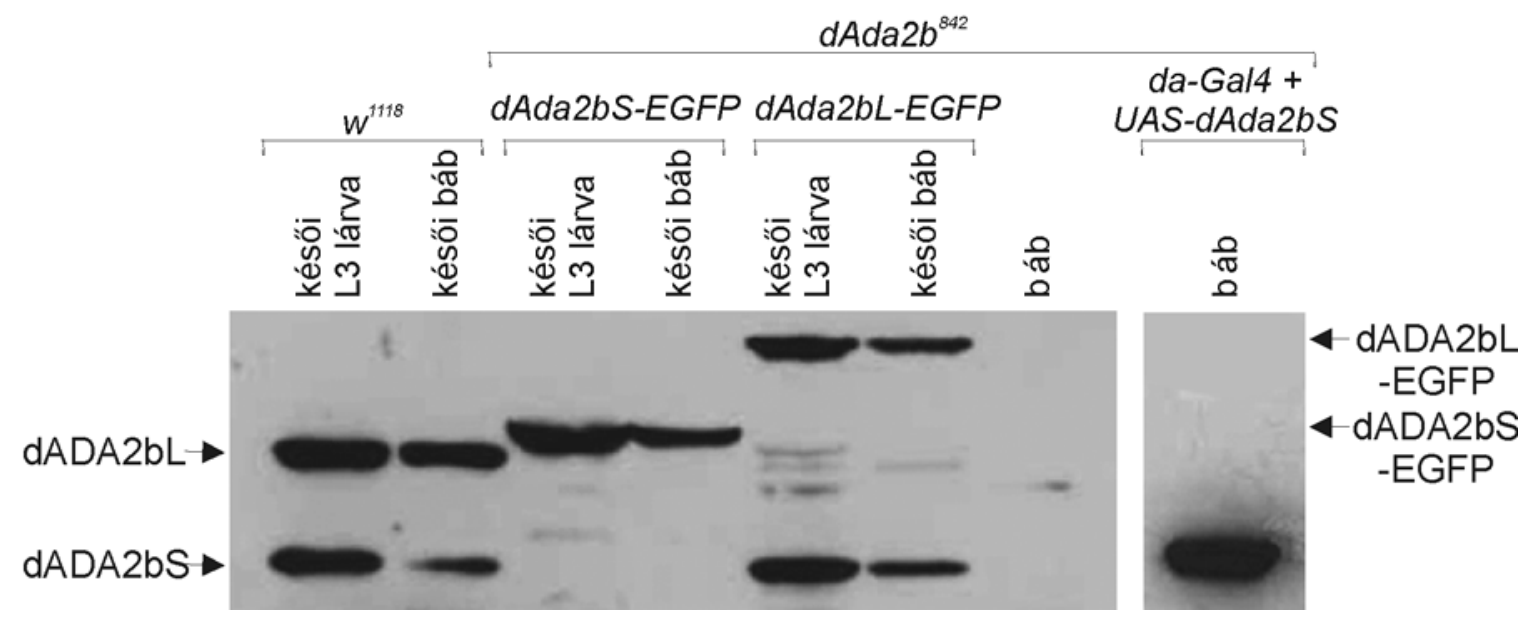

20. ábra: A dADA2b izoformák funkcionális vizsgálatához használt transzgenikus törzsek dADA2b fehérje termelése a vad típuséhoz hasonló

Az ábrán vad típusú $\left(w^{1118}\right), d A d a 2 b^{842}$ mutáns, valamint dAda2bS-EGFP, da-GAL4 + UAS$d A d a 2 b S$ és $d A d a 2 b L-E G F P$ transzgéneket tartalmazó törzsek késői L3 lárvából és késői bábból készült fehérjemintáin dADA2b specifikus ellenagyaggal készült western blot analízis eredménye látható.

A funkcionális vizsgálathoz először összehasonlítottuk, hogy a transzgénekröl történő fehérjetermelés mértéke összemérhető-e a vad típusban jelen lévő dADA2b fehérjék 
mennyiségével. Ehhez dADA2b fehérjére specifikus ellenanyaggal végzett western blot analízissel késői L3 lárva és késői báb állapotban megmértük a vad típusú ( $\left.w^{1118}\right)$ kontrollhoz hasonlítva a dAda2bS-EGFP, da-GAL4 + UAS-dAda2bS és a dAda2bL-EGFP konstrukciókról folyó dADA2b fehérjék kifejeződését (20. ábra).

Mindkét fejlődési állapotban mind az endogén expressziót, mind a túltermelést biztosító konstrukciók esetében a dADA2b fehérjék kifejeződésének mértéke a vad típuséhoz hasonló. Ezek alapján úgy ítéltük meg, hogy ezek a transzgenikus törzsek alkalmas eszközként szolgálhatnak a dADA2bS fehérje funkcionális vizsgálatára.

\subsubsection{A dADA2bS hatása a dAda2b ${ }^{842}$ deléció letális fenotípusára}

A $d A d a 2 b^{842}$ mutáns fenotípus komplementációján alapuló kísérletekkel megvizsgáltuk, hogy ha $d A d a 2 b^{842}$ mutáns háttéren egyedül a rövid izoformát expresszáltatjuk, akkor az önmagában képes-e menekíteni a mutáció okozta fenotípusokat.

Először megvizsgáltuk, hogy a $d A d a 2 b^{842}$ mutáció okozta bábletalitást képes-e menekíteni a rövidebb izoforma jelenléte. Ehhez az imént jellemzett expressziós rendszereket, a dAda2b saját promóterének szabályozása alatt termelődő (dAda2bS-EGFP), valamint az UAS-GAL4 rendszer használatával túltermeltetett (da-Gal4 + UAS-dAda2bS) dADA2bS fehérjét expresszáló törzseket használtuk. Mindkét dADA2b izoforma kifejeződését megszüntető $d A d a 2 b^{842}$ deléciót hordozó null mutáns állatok $77 \%$-a a báb állapot korai szakaszában (P5 stádium) elpusztul, míg a maradék 23\% eléri a báb állapot végét, és a kikelést megelőző állapotban (pharate adult stádium) pusztul el. Megnéztük, hogy ha csak a dADA2bS izoforma van jelen, akkor az állatok hány százaléka éri el az imágó stádiumot. A pozitív kontroll (dAda2bL-EGFP) esetében mindkét izoforma (dADA2bL-EGFP + dADA2bS) jelenléte a mutánsok több mint $80 \%$-ában volt képes a bábletalitás menekítésére (21. ábra). A rövid izoforma önmagában viszont csak részleges menekítésre képes, az endogén expresszió esetében a mutánsok 12\%-a érte el a kifejlett imágó állapotot, míg a túltermeltetett esetben már az állatok 50\%-a is kikelt. A dAda2bS-EGFP konstrukció esetében kapott gyengébb menekítés oka lehet az, hogy a közel 27 kDa nagyságú EGFP fehérje jelenléte megzavarja a dADA2bS funkcióját, esetleg a fehérje stabilitását. Mivel a 20. ábrán bemutatott western analízis alapján a $d A d a 2 b$ promóter a vad típushoz hasonló expressziós szintet biztosít, nem valószínü, hogy a látott menekítési különbséget a $d A d a 2 b$ promóter elégtelen funkciójából adódna. Ezek az eredmények arra utalnak, hogy önmagában a 
dADA2bS fehérje csak részlegesen képes ellátni a dADA2b egyedfejlődés során betöltött funkcióját.

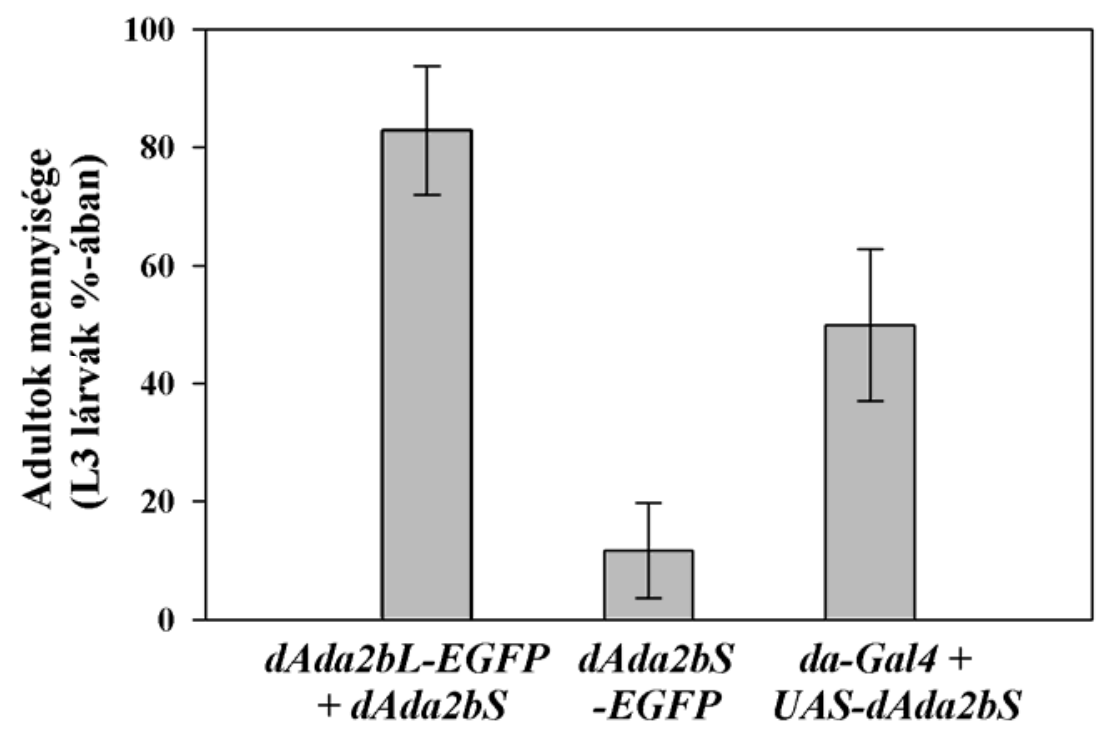

21. ábra: A dADA2bS fehérje részlegesen képes menekíteni a dAda2b ${ }^{842}$ deléció okozta bábletális fenotípust

A grafikon a $d A D A 2 b L-E G F P+d A d a 2 b S$, a dAda2bS-EGFP, valamint a da-Gal4 driver segítségével kifejezett $U A S-d A D A 2 b S$ genotípusok esetében, három párhuzamos kísérletből kapott menekítési adatok átlagát mutatja az L3 stádiumú lárvák százalékában kifejezve a kikelt Drosophilák mennyiségét.

\subsubsection{A dADA2bS izoforma szerepe a dSAGA specifikus H3K9 acetiláció} létrehozásában

Ezekből az eredményekből kiindulva megvizsgáltuk, hogy más dADA2b specifikus funkciót hogyan képes a dADA2bS fehérje ellátni. Kutatócsoportunk korábban kimutatta, hogy a dADA2b hiánya megszünteti a dSAGA komplex H3 hiszton 9-es lizinjének specifikus acetilációját [72]. Megvizsgáltuk, hogy a dADA2bS fehérje jelenléte elegendő-e ezen HAT funkció ellátásához, ezért mindkét izoformát expresszáló, valamint csak a rövid dADA2b izoformát túltermelő vándorló L3-as lárvákban western blot kísérletben megvizsgáltuk a H3K9 acetiláció szintjét (22. ábra). Mindkét dADA2b fehérje jelenlétében a dSAGA specifikus H3K9 acetiláció szintje a $d A D A 2 b$ mutánsban tapasztalt alacsony szintről visszaáll a vad típusban látott szintre. Egyedül a rövid izoforma jelenlétében is tapasztaltunk dSAGA specifikus HAT aktivitást, viszont ennek a mértéke alacsonyabb, mint a vad típusban. Ez az eredmény is arra utal, hogy a dADA2bS izoforma önmagában nem képes teljes mértékben 
ellátni a dADA2b funkciót. Tehát a dADA2bS fehérje jelenlétében létrejövő dSAGA komplex csak részlegesen képes a $\mathrm{H} 3 \mathrm{~K} 9$ acetilációra.

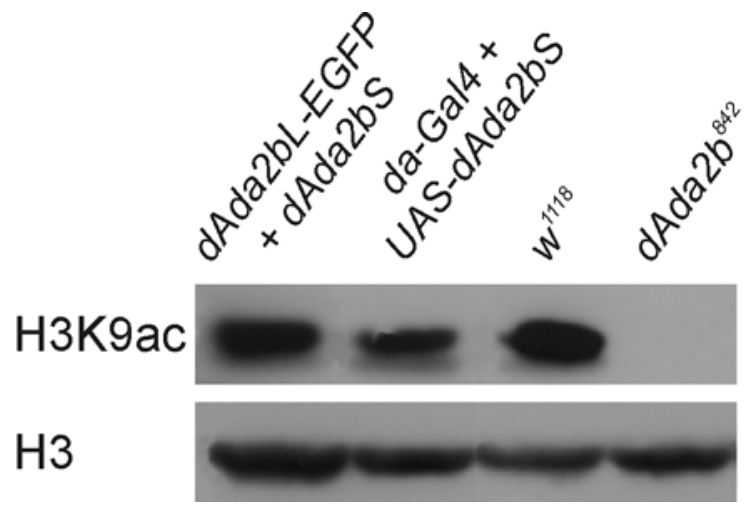

22. ábra: A dADA2bS izoforma jelenlétében csak részlegesen, míg mindkét dADA2b izoforma jelenlétében teljes mértékben képes a dSAGA komplex a H3K9 acetiláció létrehozására

A western bolt kísérlet a mindkét dADA2b izoformát expresszáló (dAda2bL-EGFP + $d A d a 2 b S$ ), valamint csak a rövidebb izoformát $d A d a 2 b$ mutáns háttéren túltermelő (da-Gal4 + UAS-dAda2bS) L3 lárvákban a 9-es lizinen acetilált $\mathrm{H} 3$ hiszton fehérjék mennyiségét mutatja a dAda2b mutáns (dAda2b $\left.b^{842}\right)$ és vad típusú $\left(w^{1118}\right)$ kontrollokhoz viszonyítva.

\subsubsection{A dADA2bS izoforma szerepe a Dmp53 által irányított apoptotikus}

\section{folyamatok szabályozásában}

Élesztőből származó adatok alapján a p53 tumor szupresszor fehérje transzkripciót aktiváló képességéhez szükség van az ADA2/ADA3/GCN5 adaptor komplex jelenlétére, valamint humán sejtekben is igazolták, hogy a p53 fehérje apoptózist indukáló képességéhez elengedhetetlen a hADA3 funkció [82]. Ezzel összhangban, a Drosophila dADA2b fehérje in vitro kölcsönhat a Drosophila p53 fehérjével (Dmp53), valamint in vivo részt vesz a Dmp53 fehérje segítségével végbemenő programozott sejthalál szabályozásában, ugyanis a $d A d a 2 b$ mutáció hatására nagy dózisú ionizáló sugárzást követően kevesebb sejt lép be az apoptózis folyamatába [59] [72]. Ezen előzetes adatokból kiindulva megvizsgáltuk, hogy a dADA2bS fehérje milyen funkciót tölthet be a Dmp53 által irányított apoptotikus folyamatok szabályozásában.

Az alkalmazott módszer elvi alapja az, hogy a nagy dózisú röntgensugárzás a DNSben kettős szálú töréseket okoz, amelyeket a sejtek - a károsodás mértékéhez viszonyítva csak kis mértékben képesek javítani. Így azok a sejtek, amelyekben a károsodás mértéke túllép egy szintet, a Dmp53 fehérje által kiváltott apoptózisban elpusztulnak [83]. A kísérletben vad típusú, $d A d a 2 b$ mutáns, valamint csak a rövid dADA2bS izoformát 
expresszáló lárvákat nagy dózisú röntgensugárzásnak tettünk ki, majd az apoptózisban elpusztult sejteket acridine orange fluoreszcens festékkel láthatóvá tettük, és imaginális diszkuszokban meghatároztuk az apoptotizáló sejtek számát. Röntgensugárzást követően a dADA2bS fehérje jelenlétében - a dAda2b mutánsokhoz hasonlóan - szignifikánsan kevesebb sejt lép apoptózisba, mint a vad típus esetén (23. ábra). Tehát, ha az dADA2 adaptorok közül egyedül a dADA2bS fehérje van csak jelen, a Dmp53 fehérje nem képes megfelelően aktiválni az apoptotikus folyamatokat.

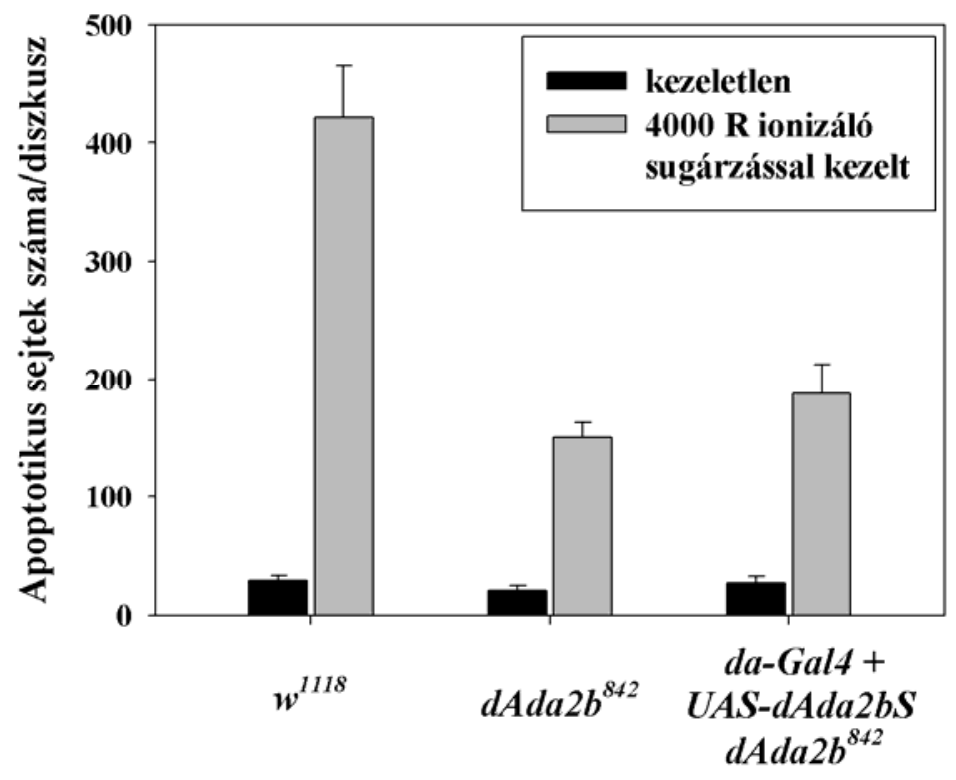

23. ábra: A dADA2bS izoforma jelenlétében ionizáló sugárzást követően csökkent mértékű apoptózis figyelhető meg

A grafikon vad típusú $\left(w^{1118}\right), d A d a 2 b$ mutáns $\left(d A d a 2 b^{842}\right)$ és a rövid dADA2b izoformát $d A d a 2 b$ mutáns háttéren kifejező (da-Gal4 + UAS-dADA2bS) kezeletlen illetve ionizáló sugárzással kezelt lárvák imágó korongjaiban az acridine orange festést mutató, apoptotikus sejtek számát a diszkuszok méretére korrigálva ábrázolja. Az ábrán három független kísérletben kapott értékek átlagai és az átlag szórások láthatóak.

Összességében elmondhatjuk, hogy bár a két dADA2b izoforma csak a C-terminális régióban különbözik egymástól, funkcionálisan mégsem ekvivalensek, ugyanis több funkciót is tesztelve, a harmadik ADA motívumot nem tartalmazó dADA2bS fehérje önmagában mégsem képes a teljes dADA2b funkció ellátására. Ennek oka nem egyszerüen mennyiségi különbségből adódik, mivel a rövid izoforma túltermeltetése is csak részleges funkciót eredményezett. 


\subsubsection{A dADA2bS izoforma transzkripció szabályozásra kifejtett hatásának vizsgálata}

A dADA2bS izoforma vizsgálatánál tapasztalt részleges menekítőképesség hátterében esetleg az állhat, hogy a dADA2bS fehérje jelenlétében létrejövő dSAGA komplex a dADA2b hiányában látott eltérő irányú génmüködés-változások közül csak az egyik irányú génexpressziós változások szabályozására képes. Ezen feltételezés igazolásához megvizsgáltuk, hogy a rövidebb dADA2b fehérje jelenléte a csökkent vagy az emelkedett expressziót mutató dADA2b-függő gének expresszióját befolyásolja. Ehhez transzkriptum analízist végeztünk $d A d a 2 b$ deléciós háttéren a $d A d a 2 b$ promóter irányítása alatt dADA2bSEGFP fehérjét termelő SpEv állapotú lárvákon, melyet összevetettük a vad típusú, valamint a $d A d a 2 b$ deléciós mutáns esetében kapott expressziós adatokkal.

A 24. ábrán látható a $d A d a 2 b$ null mutáció, valamint a dADA2bS fehérje jelenlétében a vad típustól eltérő expressziót mutató gének száma. A dAda2b deléció hatására már láthattuk, hogy 239 gén expressziója lecsökkent a vad típushoz képest, amiket dADA2b-függő géneknek tekinthetünk. Meglepő módon a dADA2bS izoforma termelődése esetén ennél több, 309 gén mutatott csökkent expressziót. Ennek hátterénben állhatnak másodlagos szabályozó hatások, például ha a dADA2bS izoforma represszor aktivitású fehérjék transzkripcióját is szabályozza. A két géncsoport közötti átfedés nagy, a dADA2b-függő gének 77\%-a a $\mathrm{dADA} 2 \mathrm{bS}$ izoforma jelenlétében is a vad típustól eltérő expressziót mutatott., míg a dADA2b-függő gének 22\%-ának (54) kifejeződéséhez a rövid dADA2b izoforma jelenléte is elegendő. A teljes $d A d a 2 b$ funkció hiányában tapasztaltakhoz hasonlóan, a dADA2bS fehérje jelenlétében is találtunk számos olyan gént (274), amelynek az expressziója a vad típusban mérthez képest megemelkedett. Az emelkedett expressziójú dADA2b-függő gének 40\%-ának (135) a kifejeződését a dADA2bS izoforma képes volt visszaállítani a normál szintre.

Láthattuk, hogy a dADA2bS izoforma a dSAGA-függő gének csak egy részének a megfelelő expressziójához elegendő. A többi dSAGA-függő gén kifejeződédéhez a hosszú dADA2b izoforma vagy esetleg mindkét izoforma együttes jelenléte szükséges.

Az elvégzett transzkriptum analízis alátámasztotta, hogy a dADA2bS izoforma önmagában a génexpressziós szabályozásában is csak egy részleges $d A d a 2 b$ funkciót képes betölteni. Bár a dADA2bS fehérje jelenlétében létrejövő dSAGA komplex alapvetően mindkét irányú génexpressziós szabályozásában szerepet játszik, a transzkripciót gátló folyamatok közvetítésében - akár elsődleges akár másodlagos hatásokon keresztül - mégis hatékonyabbnak bizonyul. 


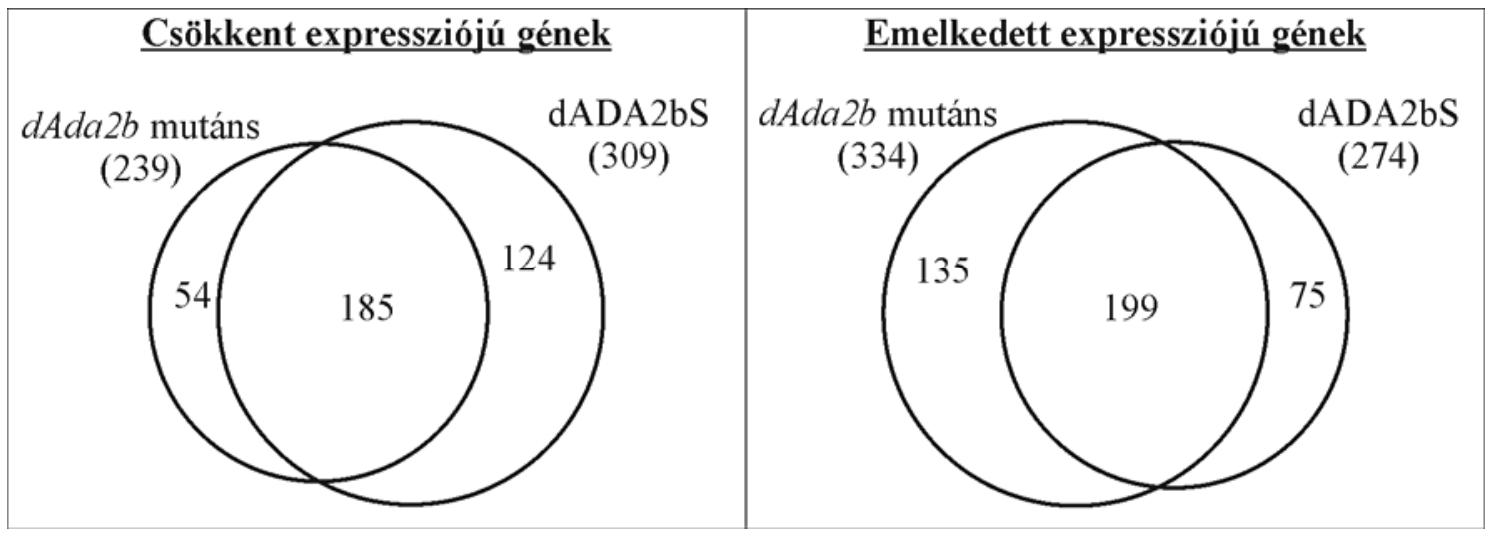

24. ábra: A dADA2bS izoforma önmagában a dAda2b-függő gének 20-40\%-ánál képes a génexpresszió szabályozásban látott $d A d a 2 b$ funkció betöltésére

$\mathrm{Az}$ ábrán látható a $d A d a 2 b$ null mutáció, valamint a dADA2bS fehérje jelenlétében a vad típustól eltérő expressziót mutató gének száma

\subsection{A dSAGA komplex által létrehozott H3K9 acetiláció a génexpresszió}

\section{szabályozásában betöltött szerepének meghatározása}

A microarray kísérletek alapján megállapítottuk, hogy a dSAGA specifikus acetiláció hiányában bizonyos gének csökkent, bizonyos gének viszont emelkedett mértékü expressziót mutatnak. Ezen változások hátterében viszont nem egy olyan jelenség áll, hogy két, a dADA2b alegység tekintetében eltérö összetételü dSAGA komplex közül az egyik az aktivációs, a másik a repressziós folyamtok szabályozásában játszana szerepet. Annak eldöntésére, hogy a dSAGA funkció közvetlen hatását láthatjuk-e mindkét irányú transzkripciós változás során, megvizsgáltuk, hogy ezek a változások együttjárnak-e a H3K9 acetiláció lecsökkenésével. Ehhez kromatin immunprecipitációs (ChIP) analízis során $w^{1118}$ és dAda2 $b^{842}$ mutáns SpEv L3 lárvák esetén meghatározott géneken megvizsgáltuk a H3K9 acetiláció szintjét és az RNS polimeráz II, valamint a dADA2b fehérje kötődését.

\subsubsection{A ChIP kísérletben vizsgált gének jellemzése}

A microarray kísérletben kapott expressziós változások alapján három kategóriába sorolhatjuk a géneket, ezek a dADA2b hiányában csökkent illetve megemelkedett expressziót, valamint expressziós változást nem mutató gének. A kromatin immunprecipitációs analízis során mind a három kategóriából vizsgáltunk géneket. A csökkent expressziót mutatók közül a sugarbabe (sug), cap and collar $(\mathrm{cnc})$ és a cyclin $B(\mathrm{CycB})$ géneket választottuk ki. A 
Cyclin B fehérje a sejtciklus egy fontos szabályozó eleme, míg a sug és cnc gének aktivátor hatású transzkripciós faktorokat kódolnak. Az emelkedett transzkripciót mutató gének közül a Frost (Fst), Hus1-like (Hus1), valamint az Attacin-D (AttD) promóter régióin vizsgáltuk meg a dSAGA specifikus acetiláció szintjét. A Frost gént azért is választottuk ki, mivel Arabidopsisban korábban már igazolták, hogy a SAGA komplex részt vesz a hideg által kiváltott stressz hatására végbemenő transzkripció aktivációban [60], a Frost fehérjét pedig a hidegstresszre indukálódó fehérjeként azonosították [84]. Az Attacin-D az immunválasz egyik szereplőjeként ugyancsak stresszválasz kialakításában, a Hus1-like pedig a sejtciklus szabályozásában vesz részt. dSAGA-független géneknek tekintettük azokat a géneket, amelyek expressziója a dADA2b fehérje hiányában nem mutatott változást. Ebböl a kategóriából a lárva stádium végén erősen expresszálódó géneket - az L32 és S23 riboszómális fehérjék génjeit (Ribosomal protein L32-RpL32, Ribosomal protein S23-RpS23) - választottuk ki az analízishez. A 25. ábra a ChIP kísérlethez kiválasztott dSAGA-függő sugarbabe, cap and collar, cyclin B, Frost, Hus1-like, Attacin-D, valamint a dSAGAfüggetlen Ribosomal protein L32, Ribosomal protein S23 transzkripciót mutató géneknek a microarray analízis során a $d A d a 2 b$ mutánsban tapasztalt expressziós változásait mutatja.

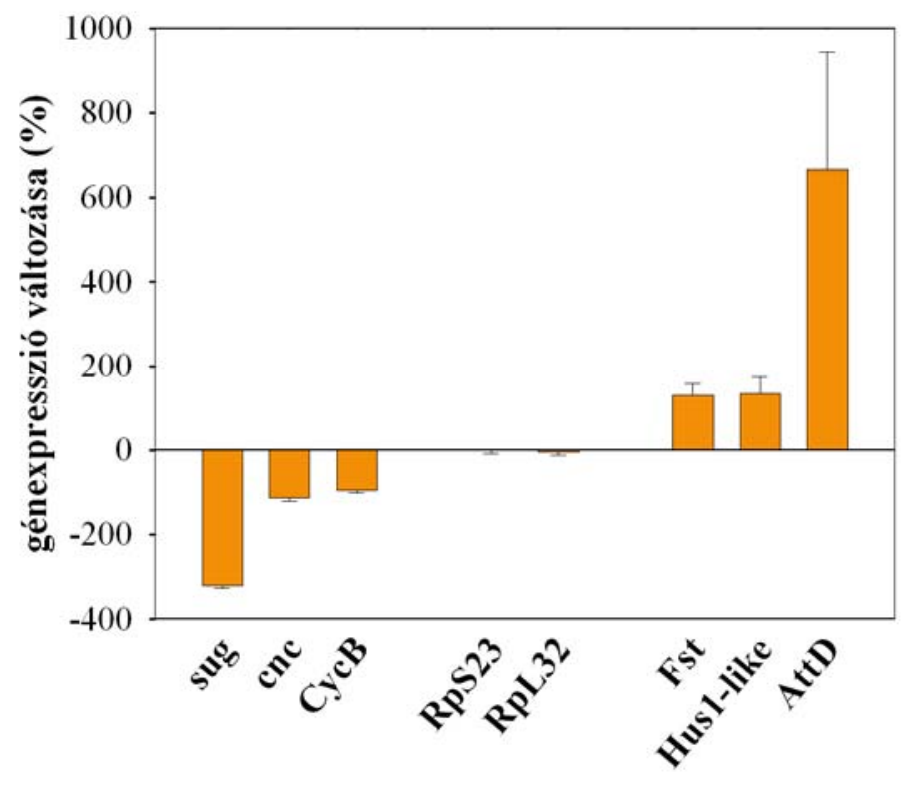

25. ábra: A ChIP analízishez kiválasztott gének a microarray analízis során, a dAda2b mutánsban tapasztalt expressziós változásai

[sug-sugarbabe, cnc-cap and collar, CycB-cyclin B, Fst-Frost, Hus1-Hus1-like, AttD-AttacinD, RpL32-Ribosomal protein L32, RpS23-Ribosomal protein S23] 
A kiválasztott gének promóter régióin, valamint a sug, cnc, Fst és Hus1 gének esetében a gén 3' végi részén is megvizsgáltuk az RNS polimeráz II, a dADA2b fehérje, valamint a H3K9 acetiláció jelenlétét. Kontrollként négy intergenikus régión (Intergenic region 1-4) is meghatároztuk a kötődés mértékét.

\subsubsection{A RNS polimeráz II mennyiségének meghatározása a módosult transzkripciót mutató gének területén}

Annak kiderítésére, hogy az RNS polimeráz II kötődése a tapasztalt expressziós változásokkal összhangban van-e, RNS polimeráz II elleni ellenanyaggal vad típusú és dAda2b mutáns lárvákon ChIP-t végeztünk a dSAGA-függő, illetve a dSAGA-független géneken. A dSAGA-független RpS23 és RpL32 génekhez kapcsolódó RNS polimeráz II mennyisége mindkét genotípus esetén közel azonos, míg a dSAGA-függő géneken a dAda2b mutánsban kapott kötődés jelentősen eltér a vad típusétól (26. ábra). Tehát a transzkripciós változásoknak megfelelően módosul a géneken jelen lévő RNS polimeráz II mennyisége: a dADA2b hiányában csökkent transzkripciót mutató géneken kevesebb, míg a fokozottan átírt gének promóterein több RNS polimeráz II mutatható ki.

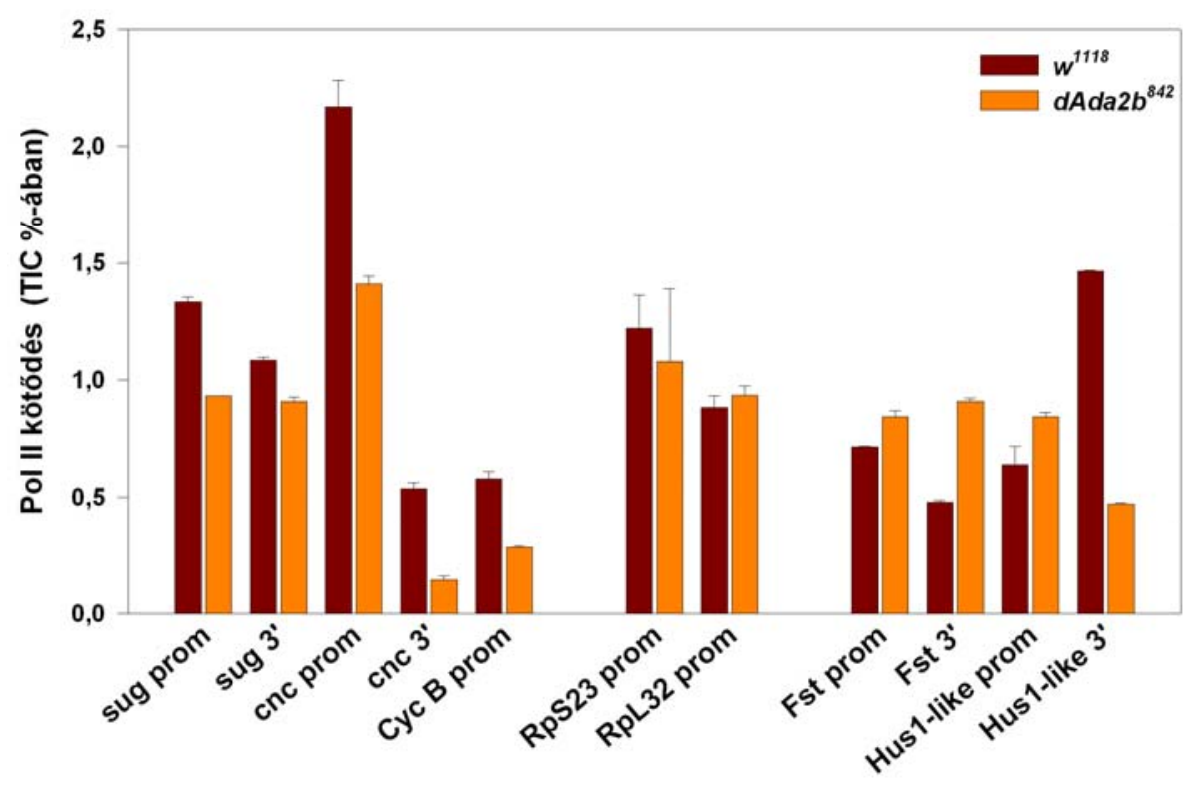

26. ábra: A dSAGA-függő gének területén a dAda2b mutáció okozta expressziós változásoknak megfelelően alakul a kötődött RNS polimeráz II mennyisége

Az ábrán a $w^{1118}$ és dAda2 $b^{842}$ mutáns mintákban Q-PCR-rel meghatározott, RNS polimeráz II által kötött genomi régiók mennyisége látható a teljes bemért kromatin \%-ában (TIC \%) ábrázolva. 


\subsubsection{A dADA2b fehérje kötődésének meghatározása a dSAGA-függö, valamint a dSAGA-független gének területén}

Ezt követően azt szerettük volna megállapítani, hogy a dAda2b mutánsok transzkriptumanalízise során eltérő expressziót mutató gének szabályozásában közvetlen funkciót lát-e el a dSAGA komplex. Ezért $w^{1118}$ és dAda2b mutáns SpEv lárvákon a dSAGA komplexre specifikus dADA2b fehérje elleni ellenanyaggal is kromatin immunoprecipitációt végeztünk (27. ábra). Ennek során a vad típusban mind a dSAGA-függő, mind a dSAGAfüggetlen gének promóterén és 3'végén is gyenge dADA2b kötődést tapasztaltunk. A dAda2b mutánsok esetén is minden vizsgált régión ugyan nagyon gyengén kimutatható volt a dADA2b kötődés, de ebben a kategóriában a kötődés erőssége általában a vad típus esetén kapott értéknek csak az $50 \%$-a volt. Ez a dAda2b mutáció jelenlétében tapasztalt csökkent mértékü kötődés arra utalhat, hogy a kimutatott kötődés valójában a dADA2b fehérje jelenlétéhez köthető. Bár teljes lárván ebben a fejlődési állapotban elvégzett western blot analízisben már nem kimutatható az anyai hatású dADA2b fehérjék jelenléte, a dAda2b mutáns esetében is tapasztalt enyhe dADA2b kötődést vagy a kromatin immunprecipitációs eljárás nagyobb érzékenységéből, vagy esetleg a dADA2b ellenanagy asecifikus kötődéséből fakadhat [85]. A fenti megfigyelés alól csak a Frost promótere és 3' régiója a kivétel, ahol a $d A d a 2 b$ mutáció esetén is hasonló mértékü dADA2b kötődést tapasztaltunk, mint a vad típusban. Ezek alapján elmondható, hogy a dSAGA-függő gének közül a sug, a cnc, a CycB és a Hus1 génekhez kötődik a dADA2b fehérje, tehát ezek a gének a dSAGA komplex direkt célgénjeinek tekinthetők. A transzkripciós adatok alapján dSAGA-független géneknek tekintett RpS23 és RpL32 gének promóter régióin is kimutatható volt a dADA2b jelenléte.

\subsubsection{A dSAGA specifikus H3K9 acetiláció szintje az eltérő irányú transzkripciós változást mutató dSAGA-függő gének területén}

A dADA2b fehérje kötődése alapján dSAGA célgéneknek tekintett régiókon megvizsgáltuk, hogy a dSAGA specifikus H3K9 acetiláció közvetlen szerepet tölt-e be a génexpresszió szabályozásában, vagyis hogy az eltérő irányú transzkripciós változást mutató géneken hogyan alakul a H3K9 acetiláció szintje. Ehhez $w^{1118}$ és dAda2b ${ }^{842}$ mutáns SpEv lárvákban dSAGA-függő és dSAGA-független transzkripciót mutató géneket, valamint intergenikus kontroll régiókat vizsgálva $\mathrm{K} 9$ acetilált $\mathrm{H} 3$ hiszton elleni ellenanyaggal ChIP kísérletet végeztünk (28. ábra). 


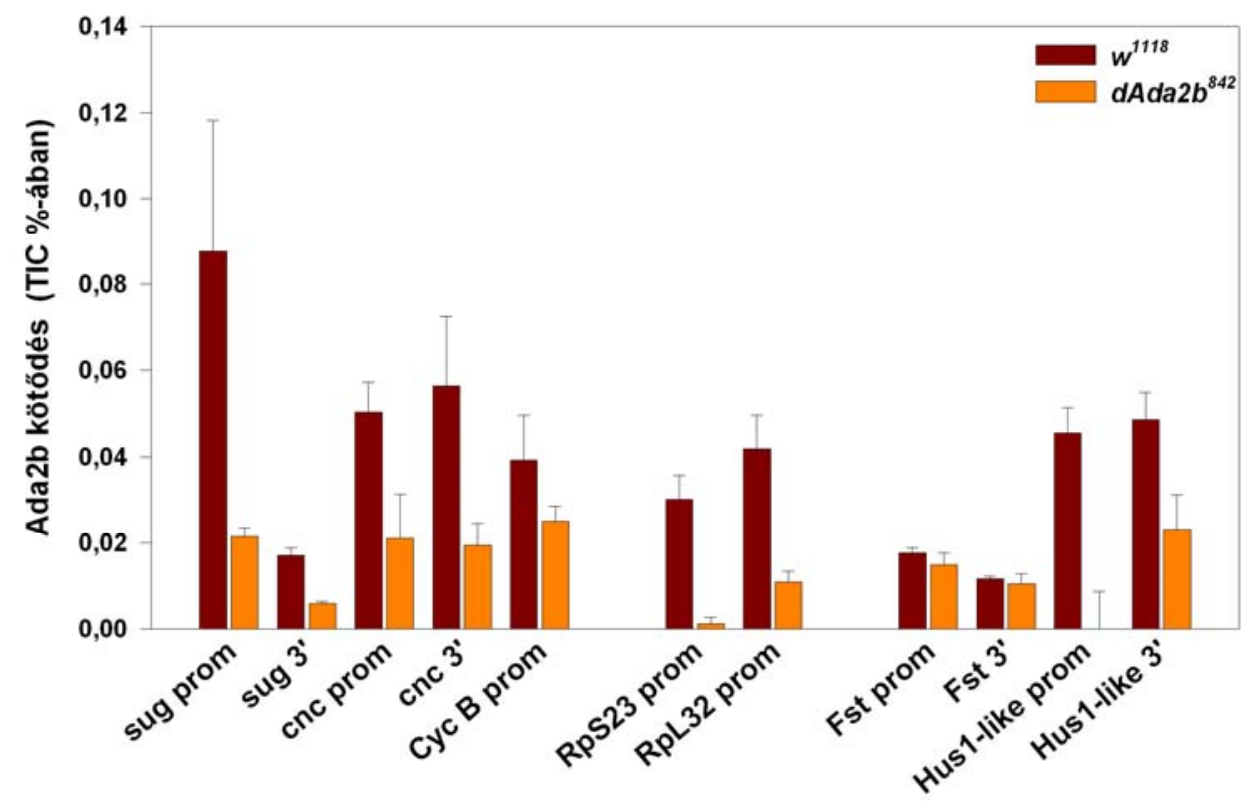

27. ábra: A dADA2b fehérje kötődése kimutatható a sug, $c n c, C y c B, H u s 1, R p S 23$ és az RpL32 gének promóter régióiban

Az ábrán a $w^{1118}$ és $d A d a 2 b^{842}$ mutáns mintákban Q-PCR-rel meghatározott, dADA2b által kötött genomi régiók mennyisége látható a teljes bemért kromatin \%-ában (TIC \%) ábrázolva.

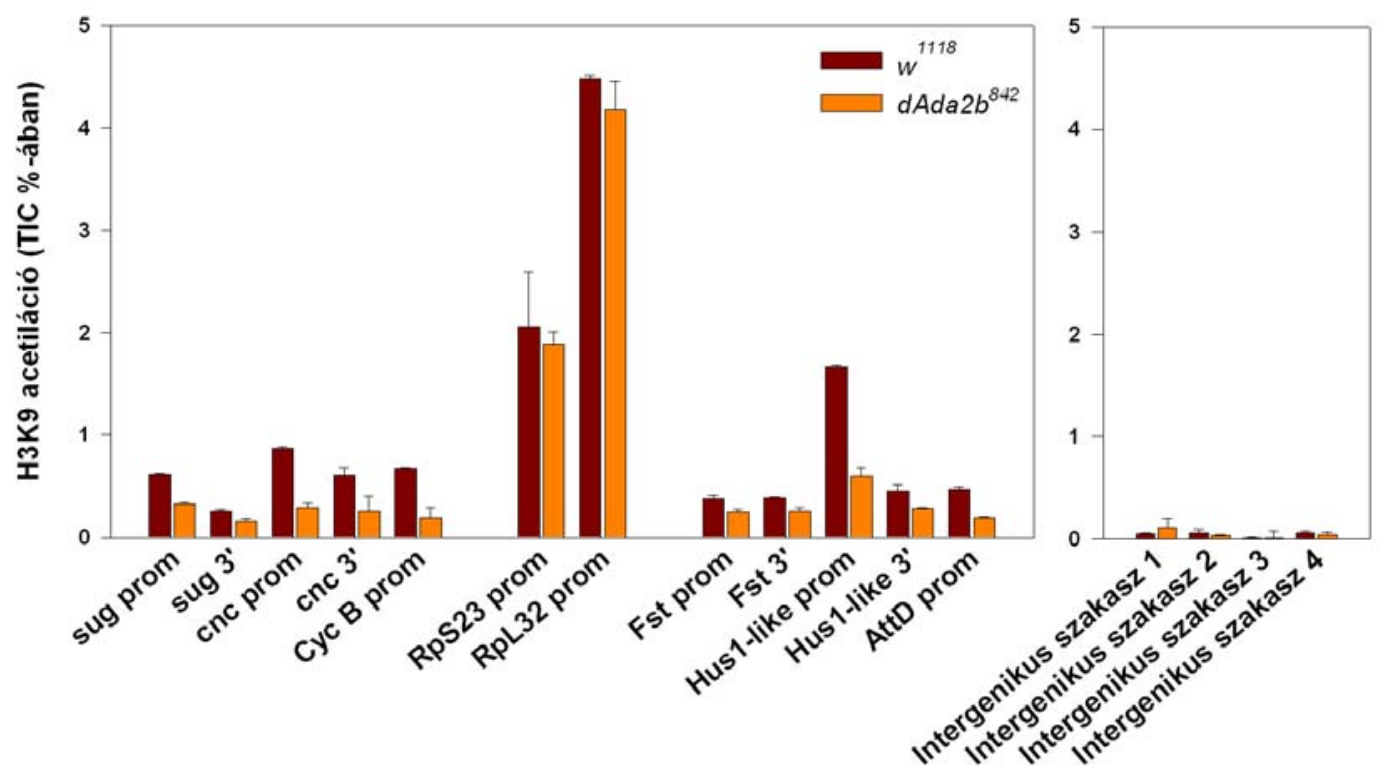

28. ábra: A H3K9 acetiláció szintje a dAda2b mutáció hatására mind a csökkent, mind az emelkedett expressziójú dSAGA-függő gének területén lecsökkent, míg a dSAGAfüggetlen és az intergenikus szakaszokon nem változott

Az ábrán a $w^{1118}$ és $d A d a 2 b^{842}$ mutáns mintákban Q-PCR-rel meghatározott, H3K9ac ellenanyag által kötött genomi régiók mennyisége látható a teljes bemért kromatin \%-ában (TIC \%) ábrázolva. 
Látható, hogy a dSAGA-független, erősen expresszálódó riboszómális fehérjék génjein (RpS23 és RpL32) rendkívül magas a H3K9ac szintje, és ez a nagymértékü acetiláltság a dADA2b fehérje hiányában is fennmaradt. Ezzel szemben a dSAGA-függő gének közül, mind a csökkent, mind az emelkedett transzkripciót mutató géneken a dADA2b hiányában lecsökkent a H3K9 acetiláció szintje. A kontrollként használt intergenikus génszakaszokon az acetiláció szintje jóval alacsonyabb volt, mint az átírt régiókon, amit a dSAGA komplex nem befolyásolt. A látott acetilációs különbségek adódhatnának abból, hogy a különböző régiókon és különböző genotípusok esetében eltérő lehet a nukleoszómák mennyisége, ezért hiszton H3 fehérje elleni ellenanyag segítségével elvégzett ChIP kísérletben a vizsgált régiók nukleoszómális lefedettségét is meghatároztuk (29. ábra). Mind a vad típus, mind a dAda2b mutáns esetében hasonló mértékü lefedettséget kaptunk az összes vizsgált régión, ami arra utal, hogy a dSAGA specifikus H3K9 acetiláció hiánya nem okoz jelentős változást a DNS nukleoszóma lefedettségében. Egy genotípuson belül a vizsgált genomi régiók nukleoszómákkal történő borítottsága között viszont jelentős különbség figyelhető meg. Ezért a H3K9 acetilációs szintre vonatkozó adatokat korrigáltuk, leosztottuk a nukleoszómális lefedettséggel, így megkaptuk, hogy a kérdéses régiókban található nukleoszómák a hiszton H3-as fehérje 9-es lizinjén milyen mértékben acetiláltak (30. ábra). Látható, hogy a magas expressziójú riboszómális fehérjék génjeinek (RpS23, RpL32) promóter régiójában található nukleoszómák nagymértékben acetiláltak, és ez a H3K9 acetiláció a dSAGA hiányában is fennmarad. Az alacsonyabb mértékben expresszálódó, dSAGA-függő gének területén lévő nulkeoszómák alacsonyabb szinten acetiláltak, és ez a H3K9 acetiláció egy része dSAGA-függö, ugyanis a dAda2b mutáció hatására szintje jelentősen lecsökken. Mind a csökkent, mind a növekedett expressziót mutató gének területén megfigyelhető ez a dSAGA specifikus H3K9 acetiláció jelenléte.

Ezen eredmények alapján elmondhatjuk, hogy a dSAGA és az általa létrehozott H3K9 acetiláció összefügg a látott transzkripciós változásokkal, viszont önmagában nem határozza meg azok irányát. 


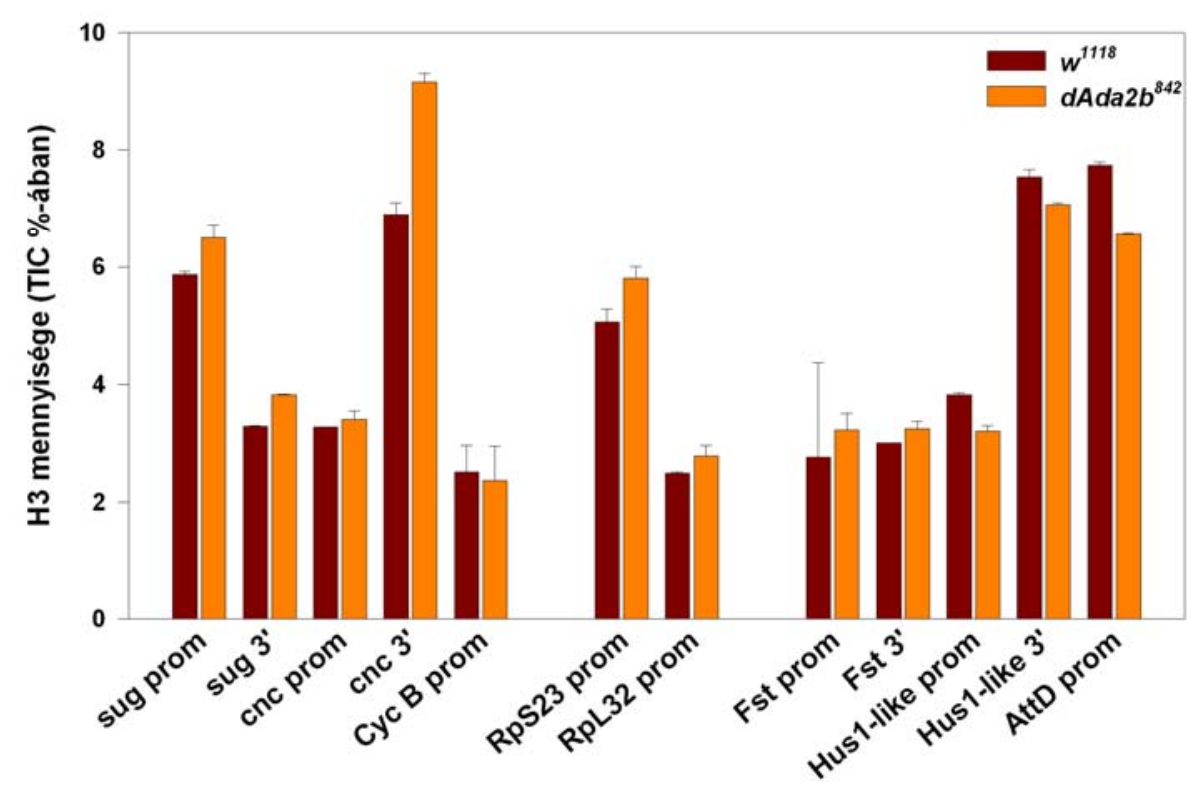

29. ábra: A vad típus és a dAda2b mutáns esetében ChIP kísérletben vizsgált régiók nukleoszómális lefedettsége hasonló, viszont egy genotípuson belül a különböző régiók között a nukleoszómák mennyiségét illetően jelentőss eltérés tapasztalható Az ábrán a $w^{1118}$ és dAda2b ${ }^{842}$ mutáns mintákban Q-PCR-rel meghatározott, H3 hiszton fehérjére specifikus ellenanyag által kötött genomi régiók mennyisége látható a teljes bemért kromatin \%-ában (TIC \%) ábrázolva.

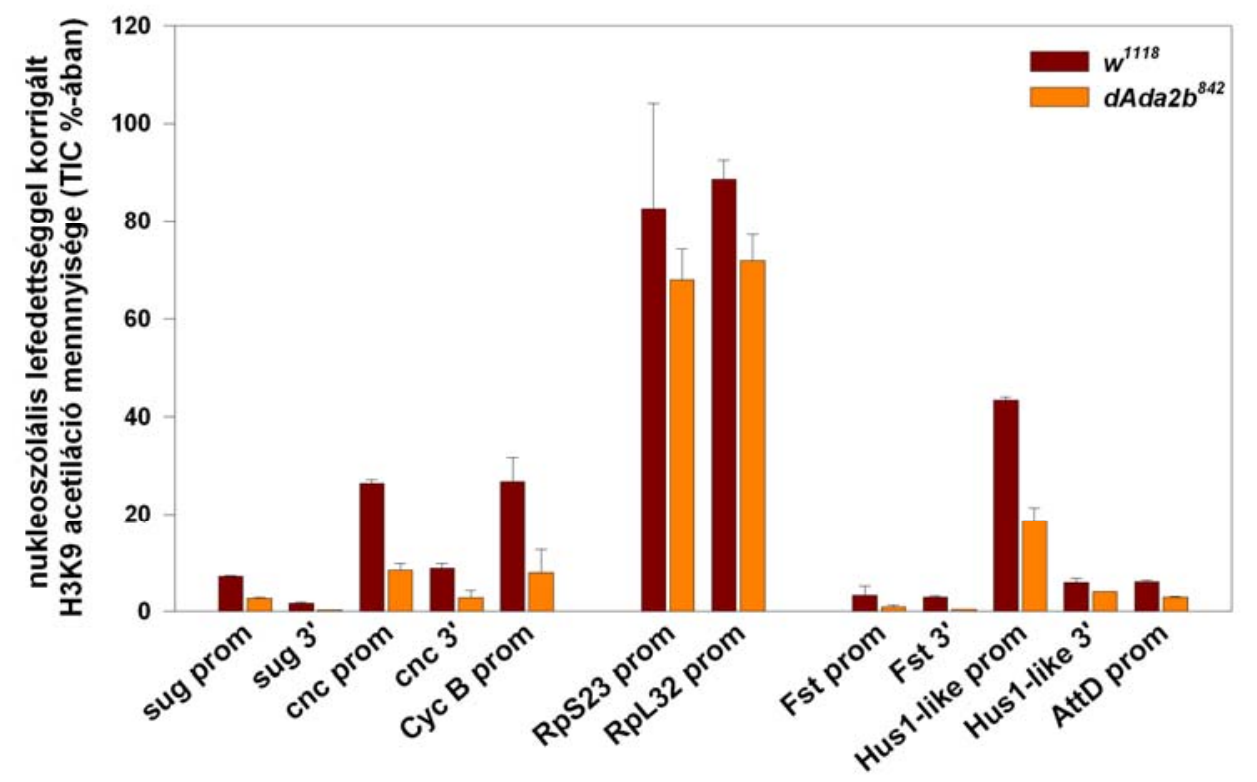

30. ábra: Az erősen expresszálódó gének területén lévő nukleoszómák a dSAGA komplextől függetlenül magas szinten acetiláltak, míg a dSAGA-független gének kisebb mértékü, dSAGA specifikus acetilációs mintázatot mutatnak

$\mathrm{Az}$ ábrán a $w^{1118}$ és $d A d a 2 b^{842}$ mutáns minták esetén a nukleoszómális lefedettséggel (H3 specifikus ChIP eredmények) korrigált H3K9 acetilációt felismerő ellenanyaggal kapott ChIP eredmények látható a teljes bemért kromatin \%-ában (TIC \%) ábrázolva. 


\subsection{A dSAGA specifikus H3K9 acetiláció génaktivációban betöltött szerepének vizsgálata}

Az eddigi eredményekből láthattuk, hogy egy jól meghatározott fejlődési állapotban a H3K9 acetiláció meghatározó szerepet tölt be bizonyos gének expressziójának szabályozásában, viszont arról, hogy a génaktiváció folyamatának szabályozásához hogyan is járul hozzá ez az acetiláció, még keveset tudunk. A dSAGA specifikus H3K9 acetiláció a génexpresszió szabályozásában betöltött szerepének további vizsgálatára egy in vivo, jól indukálható rendszert kerestünk, ahol könnyen feltérképezhető a génaktivációt kísérő acetilációs mintázat alakulása.

\subsubsection{A H3K9 acetiláció szintjének meghatározása az aktivált hősokk gének területén}

Először egy durvább megközelítésban vizsgáltuk meg, hogy egy erőteljes génindukció folyamatát hogyan befolyásolja a dSAGA specifikus H3K9 acetiláció szintje. A génexpresszió durvább, de in vivo nyomon követésére a hősokk géneket választottuk, mint könnyen indukálható és jól detektálható modellt. A génaktivációhoz $w^{1118}$ és $d A d a 2 b^{842}$ mutáns vándorló L3 lárvákban 30 perces $37^{\circ} \mathrm{C}$-os inkubációval indukáltuk a hősokk gének átírását. Ezt követően a lárvák nyálmirigyeiből óriáskromoszómát preparáltunk, és immunfestéssel meghatároztuk az aktív génátírás helyén a H3K9 acetiláció és az RNS polimeráz II jelenlétét. A kísérlet során megvizsgáltuk, hogy a génaktivációval összekapcsolt H3K9 acetiláció hiányában is kialakulnak-e az aktív génmüködést jelző, fellazult kromatinszerkezetből adódó puffok az óriáskromoszómán, valamint hogy itt, az aktív transzkripció helyén tapasztalható-e fokozott hiszton H3K9 acetiláció. A kromoszómák immunfestése során vad típus esetében sem tapasztaltuk a hősokk puffok területén az acetiláció felhalmozódását (31. ábra). Látható, hogy a dAda2b mutánsoknál a dSAGA specifikus H3K9 acetiláció hiányában is kialakulnak a hősokk puffok, és az RNS polimeráz II is kötődik ezen régiókhoz (31. A. ábra). Az RNS polimeráz II C-terminális doménjének 5-ös pozícióban található szerin foszforilált formáját felismerő ellenanyaggal végzett immunfestésből azt láthatjuk, hogy ez az aktív, átírást végző polimeráz a dADA2b hiányában is képes a hősokk génekhez kötődni, tehát feltételezhető, hogy az RNS polimeráz II H3K9 acetiláció hiányában is képes a transzkripció iniciációjára (31. B. ábra). Ebből arra 
következtethetünk, hogy a dSAGA specifikus H3K9 acetiláció jelenléte a hősokk gének esetében nem kizárólagos előfeltétele a transzkripció iniciációjának.

A

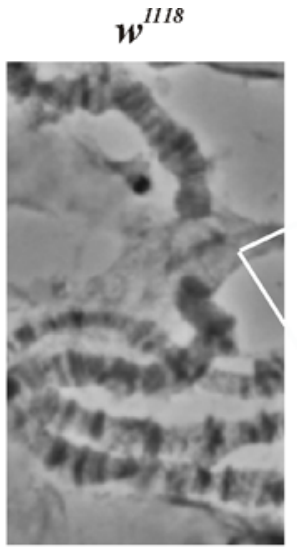

Pol II

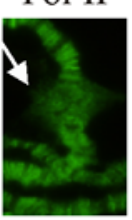

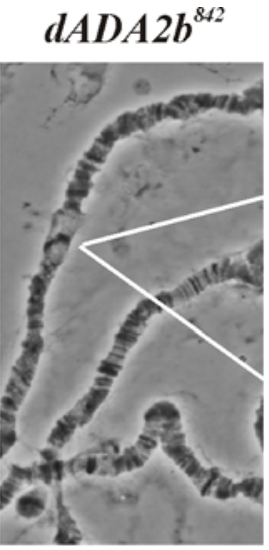

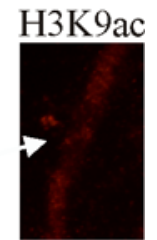

Pol II

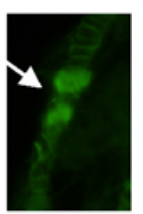

B

Fázis kontraszt $\mathrm{H} 3 \mathrm{~K} 9 \mathrm{ac}$

Pol II

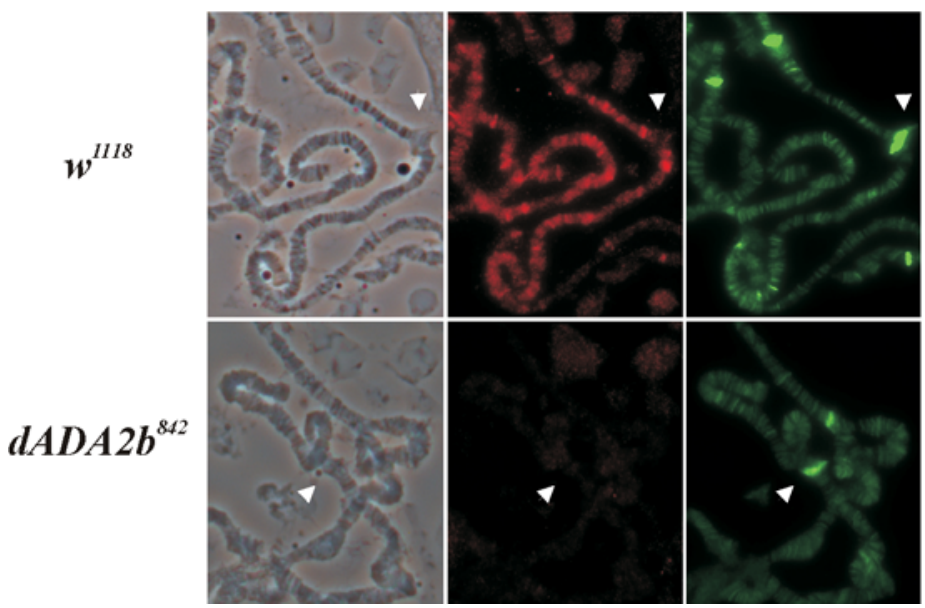

31. ábra: $w^{1118}$ és $d A d a 2 b^{842}$ vándorló L3 lárvák nyálmirigy óriáskromoszóma preparátumain a hősokk gének aktiválásakor az RNS polimeráz II kötődik a hősokk puffokba, míg a H3K9 acetiláció szintjében nem figyelhető meg emelkedés

A. A $87 \mathrm{~A} / 87 \mathrm{C}$ citológiai régióban található hősokk gének aktiválásakor kialakuló hősokk puffok területén az RNS polimeráz II mennyisége, valamint a $\mathrm{H} 3 \mathrm{~K} 9$ acetiláció szintje látható vad típusú és $d A d a 2 b$ mutáns vándorló L3 lárvákban.

B. A 93D citológiai régióban található hősokk puffokban az aktív, a C-terminális domén 5-ös szerinjén foszforilált RNS polimeráz II, valamint a H3K9 acetiláció szintje látható vad típusú és $d A d a 2 b$ mutáns vándorló L3 lárvákban.

\subsubsection{A génaktivációt kísérő H3K9 acetiláció mintázatának meghatározása az}

\section{Eip74EF és Eip75B ekdizon indukált korai géneken}

A génaktiváció teljes folyamatát kísérő hiszton acetiláció részletesebb feltérképezéséhez az ekdizon hormon által szabályozott géneket választottuk modellnek. Ez a szteroid növekedési hormon a Drosophila egyedfejlődése során jól meghatározható 
időpontokban jelenik meg, amikor a receptorához (EcR-USP) kötődve a kialakuló ligandreceptor komplex közvetlenül indukálja célgénjei transzkripcióját. Először az ún. korai gének indukálódnak, amelyek általában transzkripciós faktorokat kódolnak, amelyek további, ún. késői gének expresszióját aktiválják, amelyek kialakítják az adott állapotra jellemző génexpressziós mintázatot.

A génaktiváció során megjelenő acetilációs mintázat meghatározására két korai ekdizon által indukált gént - Eip74EF és Eip75B - választottunk ki. Mindkét gén összetett transzkripciós egység, amely több alternatív promóteréről számos transzkriptumvariáns termelődik (32. ábra). Az Eip74EF gén esetében az RA és az RB transzkriptum, az Eip75B génnél az RC variáns termelődését és promótereik acetiláltsági állapotát vizsgáltuk.
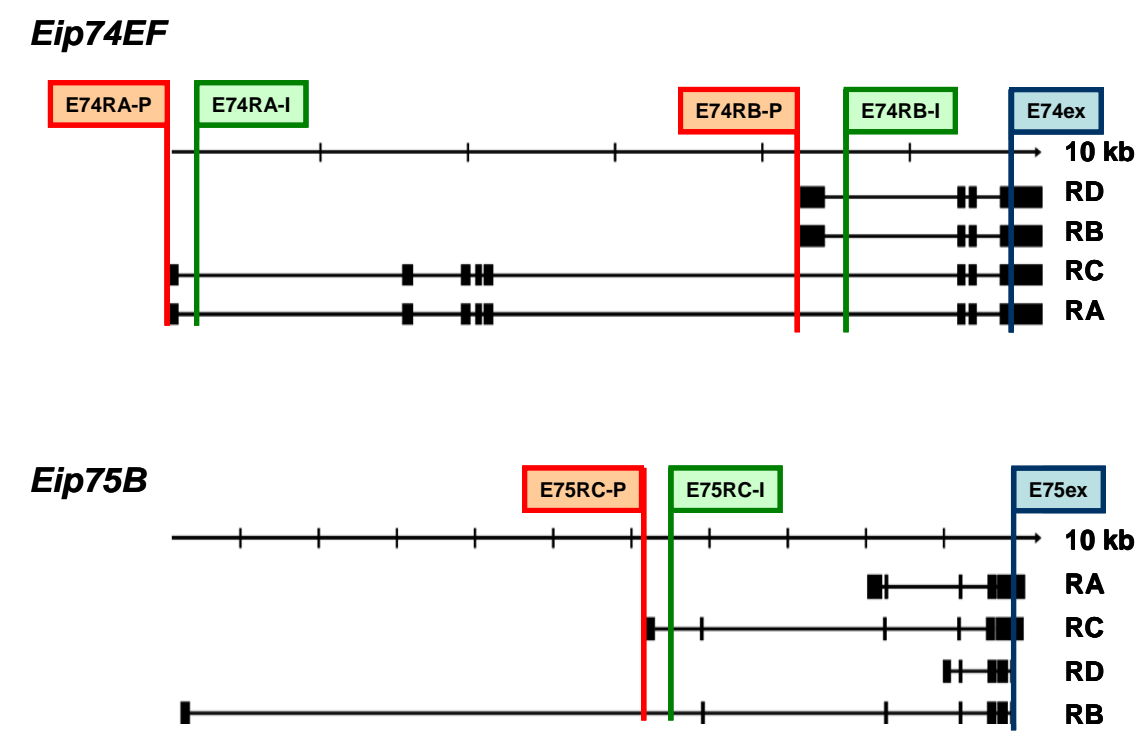

\section{2. ábra: Az Eip74EF és Eip75B gének szerkezete}

A FlyBase adatbázis alapján mindkét génről alternatív promóterek, valamint alternatív splicing mechanizmussal 4-4 transzkript variáns képződik (RA, RB, RC, RD). A génexpressziós analízis során az Eip74EF-RA, Eip74EF-RB és az Eip75B-RC variánsok termelődését vizsgáltuk az első intronok területére tervezett primer párok (E74RA-I, E74RBI, E75BC-I) segítségével. Az ábra jelöli az ChIP során használt primer párok elhelyezkedését is.

A génműködéssel kapcsolatba hozható hiszton módosítási mintázat feltérképezéséhez először meghatároztuk az L3 lárvastádium során az Eip74EF-RA, Eip74EF-RB és az Eip75BRC transzkriptumok kifejeződésének a mintázatát. Ehhez az L3 lárva stádium során 4 óránkénti felbontásban az RNS-ek első intronjára tervezett primerek segítségével megmértük a képződő transzkriptumok mennyiségét. Így az RT-PCR reakció során nem a felhalmozódó, érett mRNS-ek mennyiségét, hanem közvetlenül az indukció során termelődő nascens RNS mennyiségét határoztuk meg, amely sokkal jobban tükrözi a gén aktivitását. 


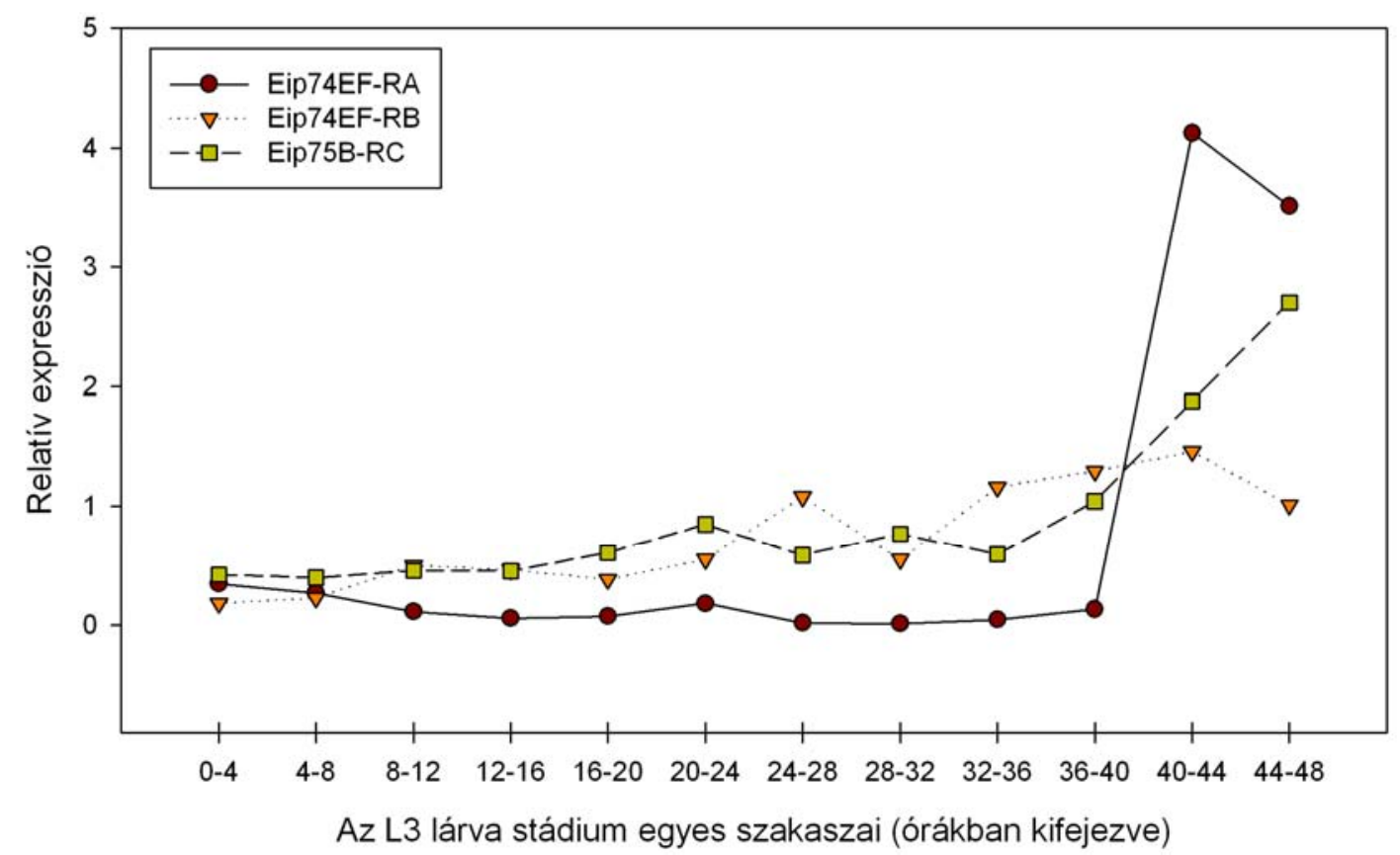

33. ábra Az Eip74EF-RA, Eip74EF-RB és az Eip75B-RC promóterek transzkripciós aktivitása az L3 lárvastádium során

Az ábrán a $w^{1118}$ állatokban a harmadik lárvastádium során az Eip74EF-RA, Eip74EF-RB és az Eip75B-RC promóterekröl képződő RNS-ek mennyisége a kontrollként alkalmazott $R p L 32$ gén expressziójához viszonyítva látható. Az ábrázolt értékek három független kísérlet átlagából származnak.

Az analízis alapján a különböző promóterek eltérő ekdizon koncentrációnál aktiválódnak, valamint a létrejött indukció mértéke is eltérő (33. ábra). Az Eip74EF-RA promóter alacsony ekdizon szintnél gyakorlatilag represszált állapotban van, majd csak az L3 lárva stádium legvégén megjelenő magas ekdizon szintnél aktiválódik. Az itt látott indukció mértéke rendkívül magas, az L3 lárva stádium elején mérthez képest több, mint húszszoros mennyiségben van jelen. Az Eip74EF-RB belső promóterről képződő RNS az L3 lárva stádium első felében alacsony mennyiségben van jelen, ami a stádium második felében egy kisebb, legfeljebb háromszoros emelkedést mutat. Ezen promóter a teljes lárva állapot során egy közepes szintű aktivitást mutat. A másik korai gén, az Eip75B RC belső promótere az Eip74EF-RB-hez hasonlóan már alacsonyabb ekdizon szintnél, az L3 stádium első felében közepes aktivitást mutat, ami az L3 stádium végére hatszorosára emelkedik. A mért génexpresszió szintje megközelíti az Eip74EF-RA promóter esetében mért szintet, viszont a létrejött indukció mértéke nem éri el az Eip74EF-RA promóter esetében tapasztaltat.

A génaktivációt kísérő H3K9 acetilációs szint meghatározásához három időpontot, egy ekdizon indukció előtti állapotot, valamint egy-egy, az indukció korai és késői fázisába eső 
időpontot választottunk ki. Ezek az időpontok könnyen és jól azonosítható egyedfejlődési stádiumoknak felelnek meg. Az indukció előtti, alacsony ekdizon szinthez köthető állapotot (28-32 h) úgy azonosítottuk, hogy 4 órás ablakkal L2-L3 lárvastádium közötti vedlésre szinkronizáltuk az állatokat, majd ettől a null időponttól számolva 28 óra elteltével gyüjtöttük össze a lárvákat. Második vizsgálati időpontnak a vándorló L3 lárvastádiumot (wL3) választottuk. Ez az L3 lárva-előbáb átmenet elött kb. 10 órával kezdődik el, amikor a lárvák elhagyják a táptalajt, nem táplálkoznak, a fiola falán „vándorolnak”. Ezt az egyedfejlődési állapotot az ekdizonszint emelkedése váltja ki. A harmadik vizsgálati időpontnak az L3 lárva állapot legvégét választottuk, amikor a rendkívül magas ekdizonszint beindítja a lárva-előbáb átalakulást $(\mathrm{SpEv})$. Ezen folyamat során a lárva mozdulatlanná válik, teste rövidülni kezd, valamint megjelennek az anterior spirákulumok. Az említett három időpontban kromatin immunprecipitációt végeztünk acetilált H3K9 elleni ellenanyaggal, és meghatároztuk acetiláció mennyiségét az Eip74EF és Eip75B gének különböző szakaszain. Specifikus primerek segítségével az Eip74EF-RA (E74RA-P), Eip74EF-RB (E74RB-P) és az Eip75B-RC (E75RC-P) promótereknek megfelelő régiót, valamint mindhárom transzkriptum esetén a promótert követő első intron területét (E74RA-I, E74RB-I, E75RC-I), valamint a transzkriptumok 3' végi exonikus régiónak (E74ex, E75ex) megfelelő genomikus területeket vizsgáltuk meg (32. ábra). Kontrollként meghatároztuk egy intergenikus régión és egy konstitutívan magas szinten átíródó gén $(R p L 32)$ promóterén is az acetiláció mennyiségét. $\mathrm{Az}$ elvégzett ChIP kísérletben az összes általunk vizsgált genomi régióban sikerült detektálni a H3K9 acetilációt (34. ábra). Az eukromatikus területen elhelyezkedő intergenikus kontroll régióhoz viszonyítva az acetiláció szintje kisebb mértékü feldúsulást mutat a promóter és az intronikus régiók területén az adott promóter aktivitásának megfelelően. Például az Eip74EF$R B$ promóter a vándorló lárva stádium során mutat legnagyobb indukciót, amely a promóteren látható acetiláció mennyiségében is tükröződik. Az Eip74EF-RA és az Eip75B-RC promóterek a SpEv állapotban látott nagymértékü aktivációnak megfelelően ebben az állapotban a legnagyobb mértékben acetiláltak. Emelett a H3K9 acetiláció mennyisége arányos volt az adott génről folyó transzkripció erősségével, ugyanis ezen módosítás szintje a kontrolként használt magas szinten expresszálódó, riboszómális fehérjét kódoló gén (RpL32) promóterén egy nagyságrenddel magasabb volt, mint a vizsgált ekdizon indukált géneken. Tehát a H3K9 acetiláció az általunk viszgált géneken egy általánosan előforduló módosítás, amely a promóterek környékén az expresszió mértékével arányos feldúsulást mutat. 


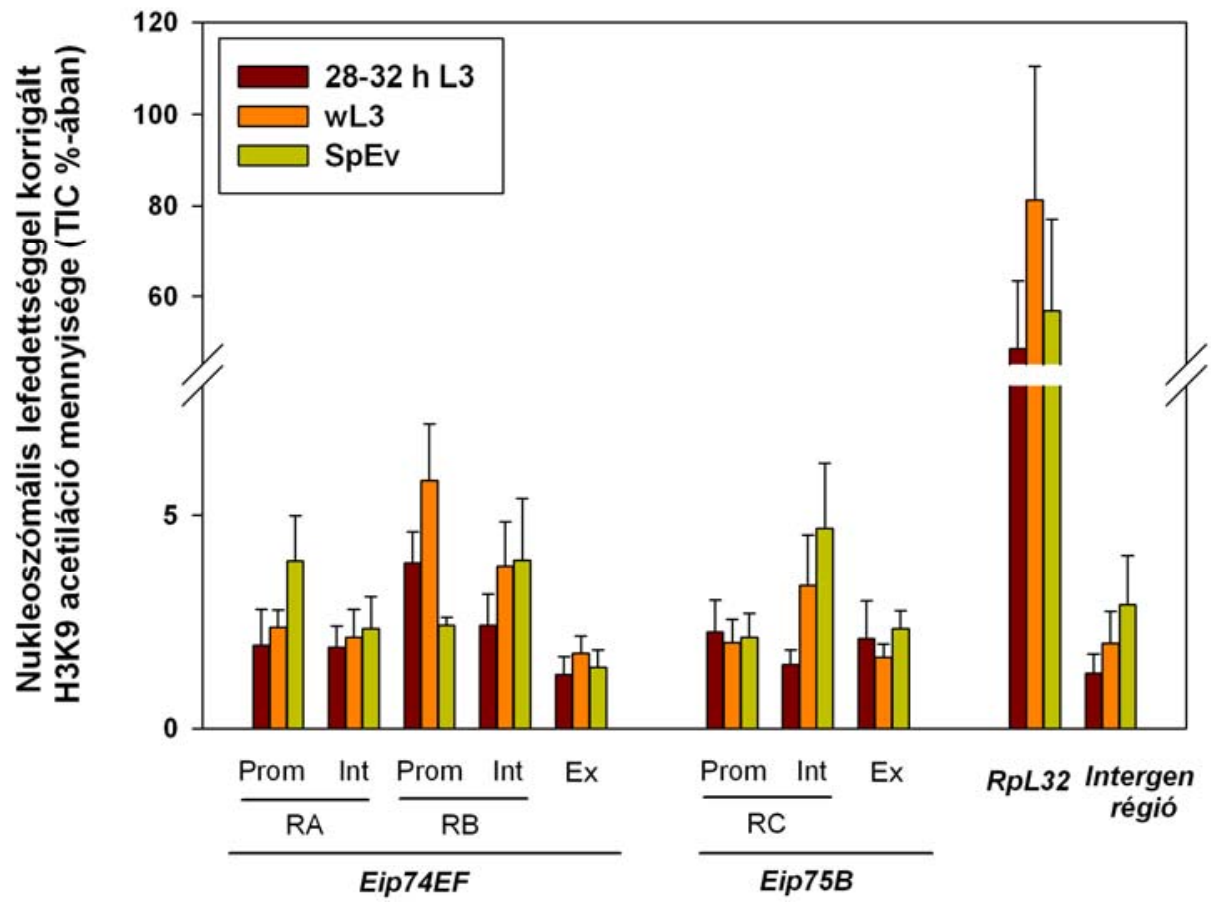

34. ábra A H3K9 acetiláció egy általánosan jelen lévő hiszton módosítás, amelynek szintje korrelál a transzkripció erősségével

$\mathrm{Az}$ ábrán a Q-PCR-rel meghatározott, H3K9ac ellenanyag által kötött genomi régiók mennyisége látható a teljes bemért kromatin \%-ában (TIC \%) ábrázolva, korrigálva az adott régió nukleoszómális lefedettségével. A grafikon három független kísérlet során kapott értékek átlagait és szórásait mutatja.

\subsubsection{Az Eip74EF és Eip75B gének aktivációja során megjelenő H3K9 acetilációs mintázat létrehozásáért felelős HAT azonosítása}

Ezt követően megvizsgáltuk, hogy a dSAGA komplex felelős-e az Eip74EF és Eip75B gének aktivációja során jelen lévő H3K9 acetiláció létrehozásáért. Ehhez H3K9ac ellen specifikus ellenanyaggal kromatin immunprecipitációt végeztünk $d A d a 2 b^{d 842}$ deléciót heterozigóta valamint homozigóta formában hordozó vándorló L3 stádiumú lárvákon (wL3) (35. ábra). Látható, hogy az Eip74EF és Eip75B ekdizon indukált géneken általánosan előforduló H3K9 acetiláció létrehozásáért a dSAGA komplex a felelős, ugyanis a dAda2b gént inaktiváló deléciót homozigóta formában hordozó lárvákban a H3K9 acetiláció szintje ezeken az ekdizon indukált géneken a felére esik vissza. A heterozigóta kontroll esetében az ekdizon indukált gének promóterei közül ebben a fejlődési állapotban a legerösebben expresszálódó Eip74RB izoforma promótere (Eip74EF-RB prom) a legmagasabban acetilált. A magas szinten átírt, dSAGA-független $R p L 32$ gén promóterének H3K9 acetilációs szintje 
egy nagyságrenddel magasabb az ekdizon indukált génekénél. Ezek az eredmények is alátámasztják a vad típusú lárvákon a H3K9 acetilációról tett megállapításunkat, miszerint ezen acetiláció mennyisége arányos az adott génről folyó transzkripció erősségével.

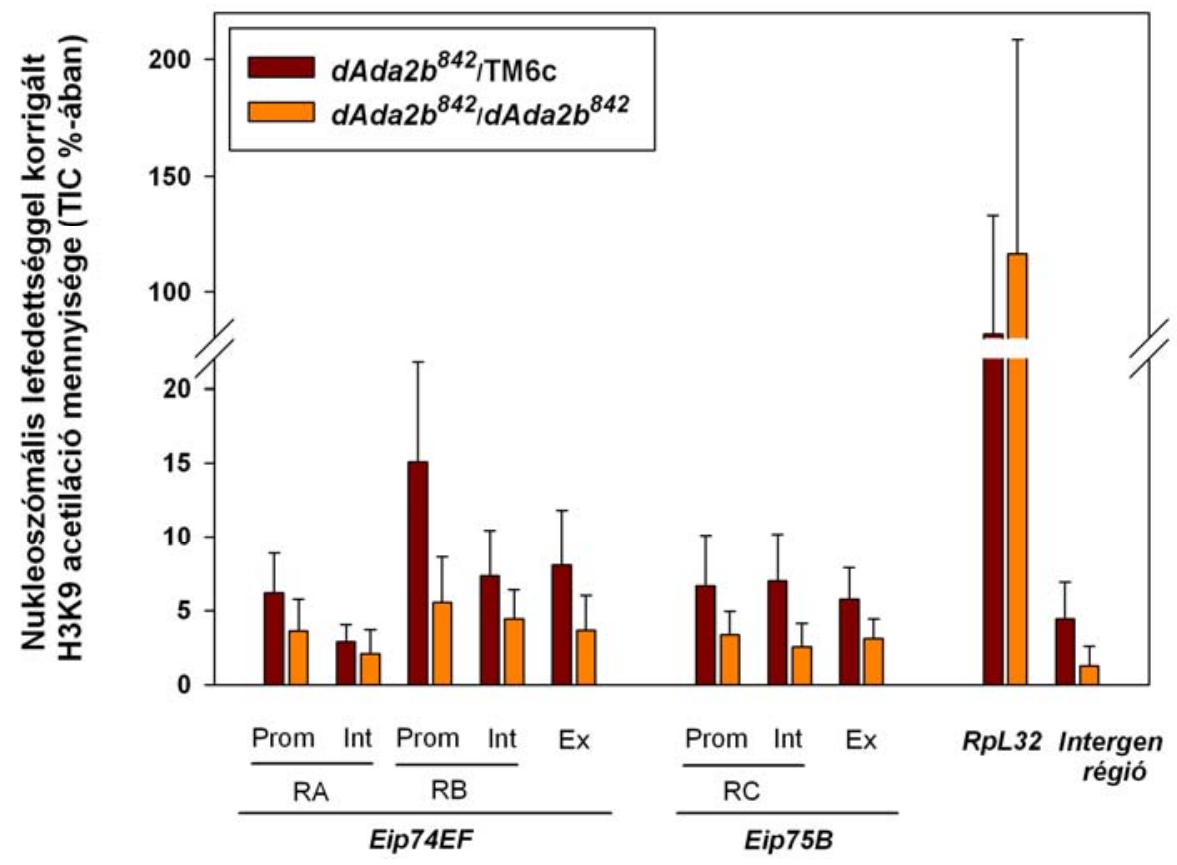

35. ábra Az Eip74EF és Eip75B ekdizon indukált gének területén jelen lévő H3K9 acetiláció létrehozásáért a dADA2b tartalmú dSAGA komplex a felelös

Az ábrán a $d A d a 2 b^{d 842}$ homozigóta mutáns $\left(d A d a 2 b^{842} / d A d a 2 b^{842}\right)$ és heterozigóta kontroll (dAda2b $\left.b^{842} / \mathrm{TM} 6 \mathrm{c}\right)$ vándorló L3 stádiumú lárvákban a Q-PCR-rel meghatározott, H3K9ac ellenanyag által kötött genomi régiók mennyisége látható a teljes bemért kromatin \%-ában (TIC \%) ábrázolva, korrigálva az adott régió nukleoszómális lefedettségével. A grafikon három független kísérlet során kapott értékek átlagait és az átlag szórásokat (SEM) mutatja.

\subsubsection{A dSAGA specifikus H3K9 acetiláció szerepe az Eip74EF és Eip75B ekdizon indukált gének aktivációjában}

Láthattuk, hogy a dSAGA specifikus H3K9 acetiláció a génaktiváció során jelen van az Eip74EF és Eip75B gének területén, és szintje összefügg az adott génről folyó transzkripció erősségével. Annak megfejtésére, hogy milyen funkciót tölt be az ezeken a génen megfigyelt H3K9 acetiláció azok aktivációja során, megmértük hogyan alakul az Eip74EF és Eip75B ekdizon indukált gének aktivációja a dSAGA specifikus H3K9 acetiláció hiányában. Ehhez RT-Q-PCR kísérletben a $d A d a 2 b^{d 842}$ deléciót homozigóta, valamint kontrollként heterozigóta formában hordozó L3-as lárvákban meghatároztuk indukció előtt, az 
indukció korai és késői fázisában a termelődő Eip74-RA, Eip74-RB valamint az Eip75-RC transzkriptum mennyiségét. Az indukció előtti állapotnak az L3 lárva stádium kezdetétől számított 24-28 órás időpontot tekintettük, a mért indukciók mértékét ehhez a kiindulási expressziós adatokhoz viszonyítottuk. A korai, valamint a késői indukciós periódusoknak az L3 lárva stádium kezdetét 40-44, valamint 46-48 órával követő időszakokat tekintettük. A korábban leírt expressziós profiloknak megfelelöen az Eip74EF-RB valamint az Eip75B-RC promóterek esetében az indukció korai és késői fázisában két-háromszoros mértékü aktivációt tapasztaltunk, amely kis mértékben csökken a dADA2b hiányában (36. ábra). Az ekdizon indukció késői fázisában az Eip74RA transzkriptum mennyiségében tapasztalt nagymértékü növekedés a dADA2b fehérje hiányában elmarad, tehát az Eip74EF-RA promóter nagymértékü indukciójához szükséges az dSAGA specifikus általános acetiláció jelenléte.
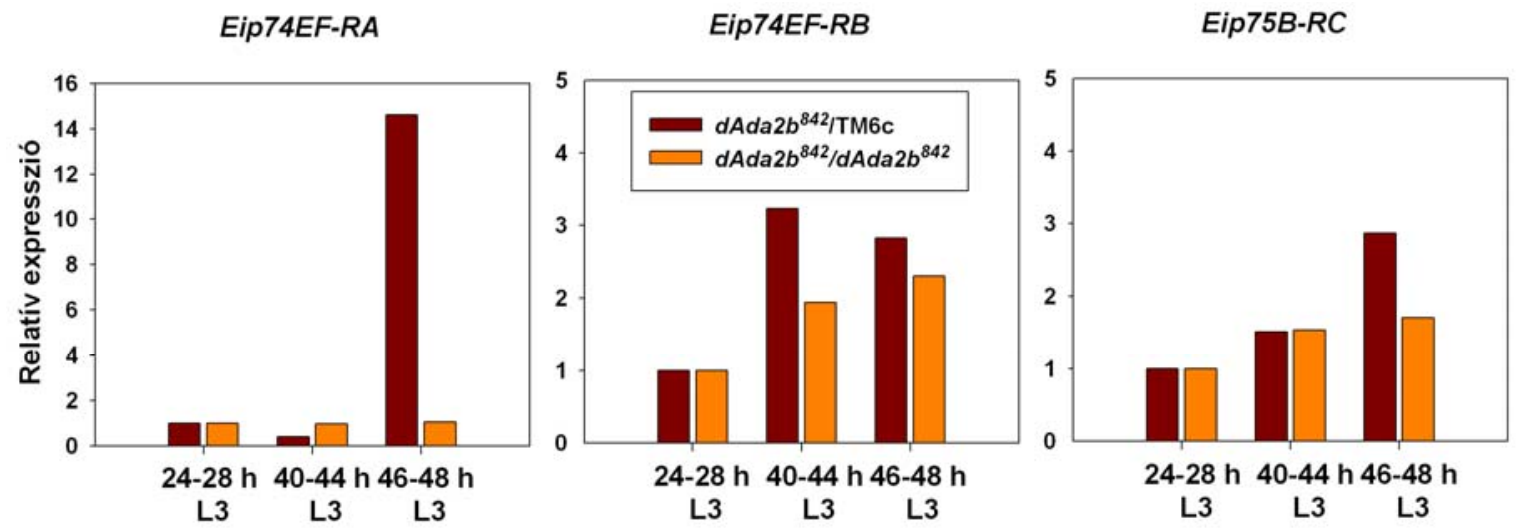

36. ábra Az Eip74EF-RA promóter aktivációja elmarad, az Eip74EF-RB és Eip75B-RC promóter indukciója csak kis mértékben csökken a dSAGA specifikus acetiláció hiányában

Az ábrán a $d A d a 2 b^{d 842}$ homozigóta mutáns és heterozigóta kontroll egyedekben az L3 lárva stádium három különböző szakaszában Q-PT-PCR kísérlettel mért Eip74RA, Eip74RB valamint Eip75RC transzkriptumok mennyisége a 24-28 órás/indukció előtti értékekhez viszonyítva látható. 


\section{Eredmények megvitatása}

A nukleoszómális hiszton fehérjék acetilációja nagymértékben hozzájárul a kromatinszerkezet dinamikus átalakításához, így fontos funkciót tölt be a transzkripció szabályozásában. Számos megfigyelés alapján a hiszton fehérjék acetilációja az aktív transzkripcióval hozható összefüggése, viszont a szabályozási folyamat pontos részletei még kevésbé ismertek. A szabályozás részleteinek megismeréséhez nagymértékben hozzájárulnak a hiszton acetiltranszferáz (HAT) enzimek vizsgálata során nyert információk. Az egyik legjobban jellemzett HAT aktivitású fehérje a Gcn5, amely több alegységes fehérje komplex tagjaként látja el acetilációs funkcióját [45]. A Gcn5-tartalmú HAT komplexek ADA-típusú adaptor fehérjéket is tartalmaznak, amelyek a Gcn5 fehérje aktivitásának és specificitásának a meghatározásában játszanak szerepet [47]. A Drosophila-ban előforduló egyik Gcn5-tartalmú HAT komplex, a dSAGA acetilációs moduljának egyik alegysége a dADA2b fehérje, amely szükséges a komplex H3 hiszton 9-es és 14-es lizinjére specifikus acetilációs aktivitásához [72]. A dolgozatomban a dADA2b funkciót eltávolító $\left(d A d a 2 b^{842}\right)$ deléció alkalmazásával meghatároztuk, mely gének szabályozásában vesz részt a dSAGA specifikus H3K9 és H3K14 acetiláció, valamint hogy e módosítások szintje hogyan befolyásolja a génaktivációt. Az ismertetett eredmények segítségével újabb információkat nyerhettünk a dSAGA specifikus H3K9 acetiláció transzkripció szabályozásában betöltött szerepéröl.

\subsection{A dSAGA acetiltranszferáz komplex szabályozása alatt álló gének}

Teljes transzkriptum analízist végeztünk vad típusú és $d A d a 2 b$ mutáns egyedeken, hogy meghatározzuk adott egyedfejlődési stádiumokban mely gének expresszióját befolyásolja a dSAGA specifikus acetiláció. Ehhez két olyan fejlődési állapotot - késői L3 lárva és korai báb állapot - választottunk, ahol a dAda2 $b^{842}$ deléció által okozott H3K9 és H3K14 acetiláció csökkenése egyértelmüen kimutatható volt. Ezekben a stádiumokban összehasonlítva a vad típus és a dAda2b mutánsok génexpressziós profilját meghatároztuk, hogy a dADA2b fehérje hiányában mely gének müködése tér el a vad típusétól. Mindkét fejlődési állapotban kevés, a gének mintegy $5 \%$-a mutatott dADA2b-függő génexpresszióváltozást. Ezen dADA2b-függő géneknek több mint a fele nem csökkent, hanem emelkedett mértékủ expressziót mutatott a dSAGA-specifikus acetiláció hiányában. Ez azért is meglepő, mivel a ySAGA komplex több alegységét is eredetileg transzkripciót aktiváló funkcióval 
rendelkező fehérjeként azonosították, valamint az élesztő yGcn5 fehérje hiányában a gének 63 \%-ának lecsökkent az expressziója [86] [87]. A mi adatainkhoz hasonlóan más magasabbrendű organizmusok esetében is azt találták, hogy bizonyos transzkripciós koaktivátorok hiányában az általuk szabályozott gének csak egy részének csökkent le a transzkripciója, a másik része viszont megemelkedett expressziót mutatott. Például Arabidopsis esetében az AtGcn5 és AtAda2b hiányában mintegy kétszer annyi gén emelkedett expressziót mutatott, mint amennyinek a transzkripciója lecsökkent [88]. Sőt, arra is találtak példát, hogy a HAT-okkal antagonista hatású, a transzkripció repressziójával kapcsolatba hozott HDAC-ok, mint például az yRPD3 fehérje hiányában több gén mutatott csökkent expressziót, mint amennyinek megemelkedett a transzkripciója [89].

Mindkét fejlődési állapotban hasonló funkcióval rendelkező gének mutattak dADA2bfüggő expressziót. A biológiai folyamtoknak megfelelő génontológiai csoportosítás során a csökkent expressziót mutató gének között mindkét stádiumban biokémiai metabolikus folyamatokban szerepet játszó gének mutattak szignifikáns felhalmozódást. Főként a báb állapotban az emelkedett expressziót mutató gének között jelentősen felülreprezantáltak a különböző immunvdekezési folyamtoknak megfelelő génontológiai csoportokba tartozó gének. Ezek az adatok a dADA2b fehérje stresszválaszban betöltött funkciójára utalhatnak, amelyet már más organizmusban is leírtak. Például élesztőben a ySAGA komplexet a környezeti stresszválaszban részt vevő gének egyik fő aktivátoraként írták le [87]. Emellett az Arabidopsis AtADA2b fehérjéröl kimutatták, hogy szerepet játszik mind a hideg-, mind a sóindukált stresszválaszban résztvevő fehérjék átíródásának a szabályozásában [88] [90].

\subsection{A dSAGA komplexre specifikus dADA2b alegység rövid izoformájának szerepe a dSAGA múködésében}

Előzetes kísérleti adatok azt bizonyították, hogy a dAda2b génről kétféle mRNS forma képződik [58]. Ezért megvizsgáltuk, hogy a dAda2b mutáció okozta, eltérő irányú génexpressziós változások hátterében állhat-e az, hogy a dADA2b alegység tekintetében kétféle felépítésü dSAGA komplex létezhet, amelyek esetleg más-más transzkripciós faktorokkal képesek kölcsönhatást kialakítani, és ezáltal az egyik típus génaktivációs, míg a másik repressziós folyamatokban részt venni.

Először kimutattuk, hogy mindkét dADA2b fehérje izoforma termelődik Drosophilában, valamint az intracelluláris eloszlásukat vizsgálva mindkettő sejtmagi lokalizációt mutatott. Expressziójuk vizsgálatakor változó mennyiségben ugyan, de az egyedfejlődés 
minden szakaszában jelen volt mindkét izoforma, legnagyobb mennyiségben az embrionális valamint a báb állapot során. Ez összhangban van azzal, hogy a $d A d a 2 b$ gén müködését megszüntető ( $\left(A d A 2 b^{842}\right)$ mutáció is a báb fejlődésének korai szakaszában okoz letalitást, így feltételezhetjük, hogy a dADA2b fehérjék fontos funkciót töltenek be a metamorfózis folyamatában [72] [73].

Megvizsgáltuk, hogy a dAda2b génről termelődő két dADA2b fehérje közül a rövid izoforma önmagában hogyan képes ellátni a teljes dADA2b funkciót. Ennek kapcsán először megállapítottuk, hogy a dADA2bS izoforma túltermeltetése csak részben, az egyedek kb. $50 \%$-ában képes a $d A d a 2 b^{842}$ deléció okozta báb állapotban jelentkező letalitás menekítésére. A dSAGA komplex acetilációs aktivitását tekintve a dADA2bS fehérje jelenlétében a vad típushoz képest csökkent H3K9 acetilációs szintet észleltünk, tehát egyedül a rövid dADA2b izoforma jelenlétében a dSAGA komplex csak részleges acetilációs aktivitásra képes. Megvizsgálva a dADA2bS izoforma funkcióját az apoptotikus folyamatok szabályozásában azt tapasztaltunk, hogy a rövid izoforma jelenléte nem állította vissza a vad típusban mért szintre az ionizáló sugárzás miatt apoptózisba lépő sejtek számát. Összességében elmondhatjuk, hogy bár a két dADA2b izoforma csak a C-terminálison régió területén különbözik egymástól, funkcionálisan mégsem ekvivalensek, ugyanis - több funkciót is tesztelve - a harmadik ADA motívumot nem tartalmazó dADA2bS fehérje önmagában nem képes a teljes dAda2b funkció ellátására. Elképzelhető, hogy a kétféle izoforma a Cterminálison lévő különbségei miatt eltérő fehérjékkel alakít ki kölcsönhatást, ezáltal más alegység összetételü és funkciójú komplexek felépítésében vehet részt.

A dADA2bS izoforma jelenlétében tapasztalt részleges $d A d a 2 b$ funkció hátterében feltételezhetünk egy olyan esetet, amikor is a dADA2bS fehérje jelenlétében létrejövő dSAGA komplex esetleg csak az egyik irányú génexpressziós változások szabályozásában képes részt venni. Ezen feltételezés helytállóságának vizsgálata céljából a dADA2bS izoformát kifejező, egyébként $d A d a 2 b$ mutáns lárvákon transzkriptum analízist végeztünk, amely során megállapítottuk, hogy a dADA2bS izoforma mind a csökkent, mind az emelkedett expressziójú dADA2b-függő gének egy részének (20 illetve $40 \%$ ) visszaállította az expressziós szintjét. Ezek alapján elmondható, hogy a dADA2bS fehérje jelenlétében létrejövő dSAGA komplex mind az emelkedett, mind a csökkent expressziójú gének szabályozásában részt vesz. Bár a represszió közvetítésében hatékonyabbnak bizonyult a rövid izoforma, itt sem volt képes betölteni a teljes $d A d a 2 b$ funkciót. A dADA2b-függő gének több, mint a felének a szabályozásához a rövid izoforma önmagában nem volt elegendő, ezen gének megfelelő átírásához valószínűleg a dADA2bL fehérjére, vagy mindkét izoforma 
egyidejü jelenlétére szükség lehet. Elképzelhető, hogy a dSAGA komplex a dADA2b izoformák segítségével valósít meg egy génspecifikus transzkripciós szabályozást, de ez nem olyan formában történik, hogy a rövid izoforma jelenlétében a dSAGA komplex kizárólag aktiváló, vagy represszáló hatást lenne képes kifejteni.

\subsection{A dSAGA komplex és az általa létrehozott H3K9 acetiláció szerepe a génexpresszió}

\section{szabályozásában}

A SAGA komplex több szinten is részt vesz a génmüködés szabályozásában. Egyrészt elősegíti a transzkripció iniciációját azáltal, hogy különböző aktivátor fehérjékkel alakít ki kölcsönhatást, és így a gén promóterén és 5' régiójában acetilálja az ott elhelyezkedő nukleoszómákat. Másrészt a TBP-vel kölcsönhatva a transzkripciós iniciációs komplex összeszerelődésén keresztül is képes befolyásolni a transzkripció aktivációját. A SAGA komplex mind az acetilációs, mind a deubiqutinációs aktivitása révén fokozza a transzkripció elongációját, valamint segíti az mRNS érésében és exportjában részt vevő fehérjekomplexek összeszerelődését [51]. Az általunk vizsgált dADA2b fehérje a dSAGA komplex hiszton acetilációt létrehozó moduljának az egyik felépítő eleme [91], amelyben meghatározza a dGcn5 fehérje szubsztrát specificitását [72].

Megvizsgáltuk, hogy a dADA2b fehérjék hiányában megfigyelt expressziós változások közül mind a csökkent, mind pedig az emelkedett mértékű génexpresszió is a dADA2b acetilációt befolyásoló hatásához köthető-e. Ehhez $w^{1118}$ és dAda2b mutáns lárvákon végzett kromatin immunprecipitációs kísérletekben dSAGA-függő (emelkedett és csökkent expresszió), illetve dSAGA-független transzkripciót mutató géneken is meghatároztuk a H3K9 acetiláció szintjét, valamint a dADA2b fehérje jelenlétét.

A dADA2b fehérje kötődése alapján több dSAGA-függő expressziót mutató gént (sug, cnc, СусB, Hus1) is direkt dSAGA célgénként tudtunk azonosítani. Mind a csökkent, mind az emelkedett expressziót mutató gének esetében is sikerült dADA2b kötődést kimutatnunk, tehát mindkét irányú expressziós változás hátterében a dSAGA komplex közvetlen működése állhat. A dADA2b fehérje jelenléte nemcsak a gének promóterhez közeli részén, hanem a 3' végi régiójában is kimutatható volt. Ez az adat azért meglepő, mivel korábbi Saccharomyces cerevisiae-ben végzett genomszintű vizsgálatok a yGcn5 fehérje jelenlétét és az általa létrehozott acetilációt a transzkripciósan aktív gének promóter és 5' végi régiójához kötötték [80] [92]. Újabb adatok szerint Schizosaccharomyces pombe yGcn5 fehérjéje erösen expresszálódó gének esetében nem csak a promóterhez közeli, hanem a teljes átírt régióhoz is 
kapcsolódik [93]. Emellett Drosophila embrionális izomsejteken a közelmúltban elvégzett vizsgálat során is több gén 3' végi régiójában is kimutatható volt a dADA2b fehérje jelenléte [94]. Az általunk elvégzett kromatin immunprecipitációban a SAGA-független expressziót mutató RpS23 és RpL32 gének transzkripciós kezdőpontjához közeli régióiban is kimutatható volt a dADA2b fehérje. Ezekhez az eredményhez hasonlóan az S. pombe esetében a yGcn5 fehérjétől független transzkripciót mutató gének átíródó régiójához is kapcsolódott a yGcn5, míg a yGcn5-függő gének esetében az átíródó régió mellett a transzkripciós kezdőpont elötti szabályozó szakaszokon is megjelent a yGcn5 fehérje. Ezt a megfigyelést a yGcn5 fehérje transzkripció elongációban betöltött szerepével hozzák összefüggésbe, mégpedig hogy a yGcn5 fehérje számos, erősen kifejeződő gén elongációját is szabályozza, viszont ez a funkciója rendundáns, ezért a yGcn5 hiányában ezen gének expressziója nem mutat jelentős változást. yGcn5-függő transzkripciót mutató gének esetében nem csak az elongációban, hanem a transzkripció iniciációjában is jelentős és esszenciális funkciót tölt be a yGcn5 fehérje [93]. Mindemellett Drosophila embrionális sejtekben a dSAGA komplex föként a gének promóterhez közeli régiójához kötődött, viszont számos esetben az átíródó régió egészén is kimutatható volt. Ebben az esetben a dSAGA az RNS polimeráz II-höz teljesen hasonló kötődési mintázatot mutatott, mely ugyancsak a komplex elongációban való részvételére utalhat [94]. Ehhez hasonlóan az általunk kimutatott dADA2b kötődési mintázat hátterében is állhat az, hogy a dSAGA komplex nem csak a transzkripció iniciációs, hanem elongációs lépését is szabályozhatja. Az, hogy ezekhez a folyamatokhoz a komplex acetilációs, illetve a deubiquitinációs aktivitása milyen mértékben járul hozzá, még kevéssé tisztázott.

Megvizsgálva a dSAGA-függő expressziót mutató gének H3K9 acetilációs szintjét azt tapasztaltuk, hogy mind a csökkent (sug, cnc, CycB), mind az emelkedett (Fst, Hus1, AttD) expressziójú gének területén megjelent a dSAGA specifikus H3K9 acetiláció. Élesztő és Drosophila sejtekből származó adatokhoz hasonlóan - miszerint a dSAGA specifikus H3 acetiláció a gének promóter és 5' végi régiójában dúsul fel [94] [95] - az általunk vizsgált dSAGA specifikus H3K9 acetiláció is a vizsgált gének promóterhez közeli régióján jelent meg magasabb szinten. A dSAGA-független (RpS23, RpL32), erősen expresszálódó géneken jelen lévő nagymértékü H3K9 acetiláció a dADA2b fehérje jelenlététől függetlenül is fennmaradt. Megállapíthatjuk, hogy a promóterhez közeli régióban a dSAGA specifikus H3K9 acetiláció jelenléte számos gén szabályozása során esszenciális, viszont a transzkripció folyamata során nem csak aktiváló, hanem represszáló hatás kialakításához is hozzájárulhat. 


\subsection{A dSAGA specifikus H3K9 acetiláció szerepe a génaktiváció folyamatában}

A fenti kísérletekkel azonosítottuk azokat a géneket, amelyek kifejeződését a két vizsgált fejlődési állapotban befolyásolja a dSAGA specifikus hiszton acetiláció. Hogy megtudjuk, ez az acetiláció hogyan járul hozzá a génaktiváció folyamatához, feltérképeztük a génmüködés során a dSAGA specifikus H3K9 acetiláció szintjét, valamint annak az adott gén transzkripciójára kifejtett hatását is. A nyálmirigy óriáskromoszómákon elvégzett immunfestés során megállapítottuk, hogy a dSAGA specifikus hiszton acetiláció nem kizárólagos előfeltétele a transzkripció iniciációjának, ugyanis az átírást végző RNS polimeráz csökkent H3K9 acetiláció mellett is képes az aktiválódó hősokk génekhez kötődni. Az acetiláció szerepének részletesebb tanulmányozásához az ekdizon hormon által indukált Eip74EF és Eip75B korai gének vizsgálatát választottuk eszköznek. Először feltérképeztük ezen gének aktivációs profiljait, majd az ezek alapján kiválasztott indukció előtti és két indukció alatti időpontban kromatin immunprecipitációs kísérlettel meghatároztuk, hogy hogyan alakul a H3K9 acetiláció mennyisége a gének promóter, promóterhez közeli intronikus, valamint 3' véghez közeli exonikus régióiban. Mindkét gén szerkezete erősen összetett, több alternatív promóter régióról több transzkriptum variáns képződik. Ezek közül az Eip74EF esetében két (RA és RB), az Eip75B esetében pedig egy (RC) transzkriptum képződését és átírásának szabályozását vizsgáltuk. Az említett három transzkriptum eltérő expressziós mintázatot mutatott: más ekdizon koncentrációnál aktiválódtak, valamint expressziójuk szintje is jelentősen eltért. Az elvégzett ChIP kísérlet eredménye azt sugallja, hogy a H3K9 acetiláció a vizsgált régióban egy általánosan jelen lévő hiszton módosítás, ami nem mutat kifejezett régió specificitást. A génaktiváció folyamatával kapcsolatban sem tapasztaltunk olyan jellegü összefüggést, hogy csak az adott transzkriptum expressziója idején jelenne meg ez a módosítás. Egyedül az adott promóterek müködésének megfelelően a promóterekhez közeli régiókban mutatott enyhe emelkedést a H3K9 acetiláció mennyisége. Emellett az általunk vizsgált géneken az acetiláció mennyisége arányos volt a transzkripció mértékével, az erőteljesebben expresszálódó gének promóterén magasabb H3K9 acetilációs szint volt megfigyelhetö.

Megvizsgáltuk, hogy az Eip74EF és Eip75B gének aktivációja során detektált H3K9 acetilációhoz milyen mértékben járul hozzá a dSAGA komplex müködése. A dAda2b mutáns vándorló L3 stádiumú lárvákon (wL3) elvégzett kromatin immunprecipitációs kísérletekből látható, hogy a dADA2b hiányában a H3K9 acetiláció szintje az általunk vizsgált összes génszakaszon és intergenikus régióban lecsökkent. Tehát a dSAGA komplex az Eip74EF és 
Eip75B gének esetében nemcsak a promótereken előforduló, hanem egy általánosan jelen lévő H3K9 acetilációs mintázat létrehozásáért felelős. Már az élesztő yGcn5 fehérjéről is leírtak egy ehhez hasonló, nagyobb kiterjedésü, kódoló és intergenikus területeket egyaránt érintő általános acetilácós aktivitást [31].

Az élesztő yGen5 fehérje koaktivátor funkciója mellett az általa létrehozott általános acetilációs mintázat is hozzájárul a transzkripció szabályozásához [32]. Ebből kiindulva megvizsgáltuk, hogyan alakul az Eip74EF és Eip75B gének aktivációja a dADA2b fehérje hiányában. Az elvégzett Q-RT-PCR kísérletben azt tapasztaltuk, hogy a kisebb mértékben aktiválódó Eip74EF-RB és Eip75B-RC promóterek indukciója a dSAGA specifikus H3K9 acetiláció hiányában csak kevésbé sérül, míg az erőteljes indukciót mutató Eip74EF-RA promóter aktivációja elmarad. Tehát az Eip74EF és Eip75B gének területén általánosan jelen lévő dSAGA specifikus H3K9 acetilációs mintázat fontos szabályozó szereppel bír ezen gének aktivációjának szabályozásában. Ezek az adatok is alátámasztják azt a tényt, hogy nem csak az irányított, a különböző szabályozó szekvenciákon megjelenő acetiláció, hanem az eukromatikus régiókban általánosan jelen lévő acetilációs mintázat is fontos szerepet tölt be a génexpresszió szabályozásában [96]. Ez az általános alapacetilációs mintázat a génműködés megfelelő kinetikájához is hozzájárulhat, például élesztő rpd3 és hda1 HDAC-okat érintő mutációk hatására a megemelkedett alapacetilációs mintázatnál a PHO5 gén repressziója jelentős késéssel következik csak be. Feltételezhetően ennek az az oka, hogy az általános acetilációs mintázatot beállító HDAC-ok müködésének részleges kiesése miatt több időre van szükség ahhoz, hogy a génaktivációt kísérő magasabb acetilációs szint visszatérjen az alapállapothoz [31]. Mivel ezt az általános alapacetilációs szintet az ellentétes aktivitású HAT és HDAC enzimek tartják fent, elképzelhető egy olyan mechanizmus, miszerint a HAT-ok müködésének kiesése kapcsán létrejövő csökkent alapacetiláció mellett több időre van szükség ahhoz, hogy az adott gén elérje az aktivációhoz szükséges acetiláltsági szintet, és ezáltal sérül a génaktiváció kinetikája.

\subsection{A dSAGA specifikus hiszton acetiláció feltételezett funkciója a génmüködés} szabályozásában

A dolgozatomban leírt eredmények összefoglalásául megállapíthatjuk, hogy a dSAGA HAT komplex rendkívül összetett módon járulhat hozzá a génmüködés szabályozásához. Egyrészt különböző transzkripciót szabályozó fehérjékkel közvetlenül kölcsönhatva szerepet játszhat egy irányított, helyspecifikusan megjelenő acetiláció létrehozásában, amely 
befolyásolhatja a transzkripció iniciációját és elongációját is [94]. Emellett a dSAGA részt vesz egy általánosan megjelenő acetilációs alapmintázat fenntartásában is [31]. Drosophila lárvák nyálmirigy óriáskromoszómáinak immunfestésén is megfigyelhettük ezt a teljes kromoszómán általánosan megjelenő dSAGA specifikus H3K9 acetilációt [72]. Ez a kétféle acetiláció nem egymástól függetlenül jelentkezik, hanem a HAT és HDAC komplexek koordinált müködése következtében egy dinamikusan változó acetilációs háttéren jelenhet meg egy irányított, helyspecifikus acetiláció. Ez az általános acetiláció hozzájárulhat egy olyan kromatinszerkezet kialakításához, amely lehetőséget biztosít a különböző szabályozó fehérjék - aktivátorok és represszorok - szekvencia-specifikus kötődésére [96]. Az elvégzett kromatin immunprecipitációs kísérletben láthattuk, hogy a dSAGA elégtelen müködése következtében sérült az eukromatikus részek általános $\mathrm{H} 3 \mathrm{~K} 9$ acetilációs mintázata. Elképzelhető, hogy ennél az alacsonyabb acetiláltságú kromatinszerkezetnél gyengül a szabályozó fehérjék kromatinhoz való kötődési képessége, és ezáltal - attól függően, hogy aktivátor vagy represszor hatású fehérjéről van szó - módosul az általuk szabályozott gének működése. Részben ez magyarázhatja, hogy a dSAGA specifikus acetiláció hiányában nem csak csökkent, hanem emelkedett expressziójú géneket is azonosítottunk (37. ábra). Ezenfelül ez az általánosan megjelenő, dinamikusan változó acetilációs mintázat hozzájárulhat a génszabályozás megfelelő kinetikájához [96]. Az általunk használt in vivo modell géneken (Eip74EF és Eip75B) bizonyítottuk, hogy a dSAGA specifikus H3K9 acetiláció hiányában sérül a génaktiváció folyamata. Ezt a megfigyelést támasztja alá az a - munkacsoportunk által elvégzett - kísérlet is, amelyben látható, hogy a Drosophila egyedfejlődés több állapotában a dAda2b mutáció hatására számos gén esetében az aktivációs (Eig71Ec, Eig71Ed, Eig71Eg, Eig71Eh) és a repressziós (Lcp1, Lcp4) folyamatok kinetikája is sérül [85]. Tehát elképzelhető, hogy a dSAGA specifikus általános H3K9 acetilációs mintázat hiányában bizonyos gének aktivációja nem a megfelelő időben történik meg, és ezáltal teljesen felborulhat a sejtre jellemző koordinált génexpressziós mintázat. Tehát a dSAGA komplex acetilációs aktivitása közvetett módon, egy transzkripciót megengedő kromatinszerkezet fenntartásán keresztül is hozzájárul a génmüködés szabályozásához (37. ábra). 


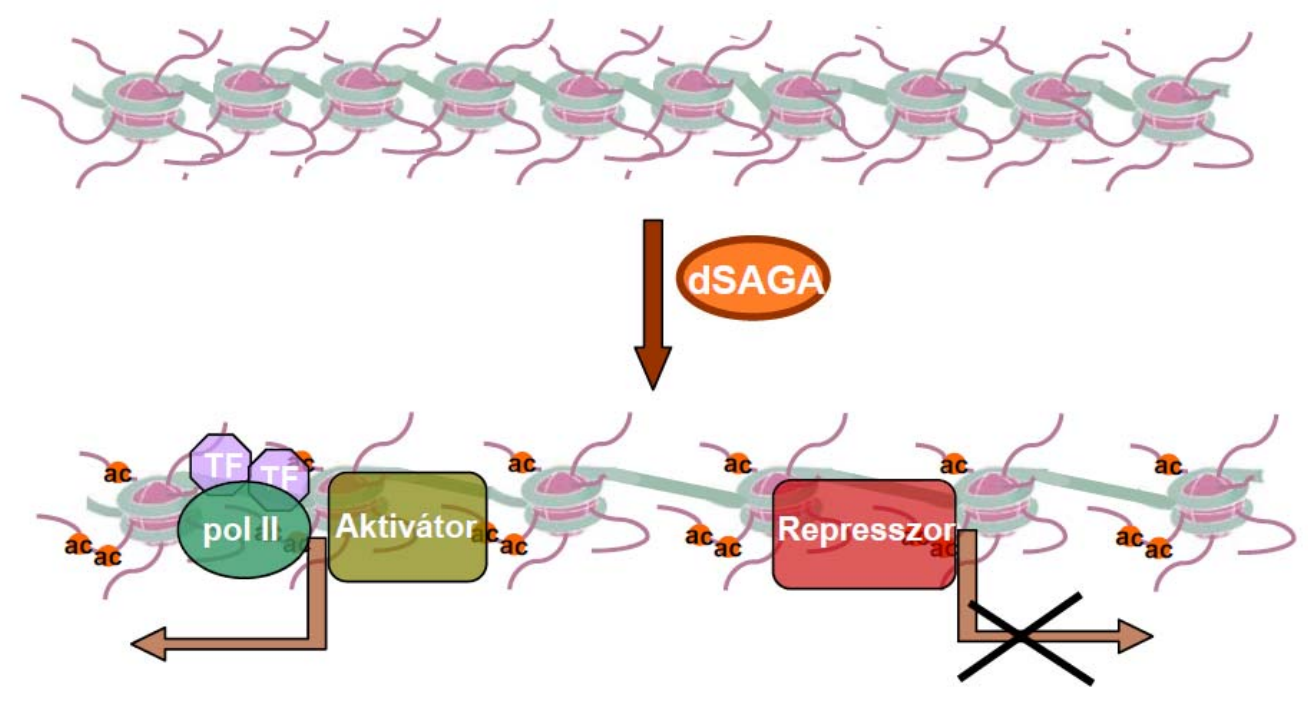

37. ábra: A modell a dSAGA specifikus acetilációs alapmintázat - egy transzkripciót megengedő kromatinszerkezet fenntartásán keresztül - a génmüködés szabályozására kifejtett hatását mutatja be 


\section{Köszönetnyilvánítás}

Köszönettel tartozom témavezetőmnek, Dr. Boros Imrének a munkámban, szakmai előmenetelemben való lelkiismeretes irányításáért, és a lehetőségért, hogy laboratóriumában betekintést nyerhettem a tudományos kutatómunka világába.

Hálás köszönettel tartozom Dr. Bodai Lászlónak, hogy rendkívüli türelemmel és kitartással precíz és önálló kutatómunkára tanított, valamint hogy bármikor fordulhattam hozzá kérdéseimmel és számíthattam támogatására.

Szeretném megköszönni Dr. Komonyi Orbánnak és Dr. Pankotai Tibornak, hogy megtanították a genetika és a molekuláris biológia gyakorlati alkalmazását, valamint a kísérletek elvégzése során nyújtott segítségüket.

Köszönettel tartozom a Biokémiai és Molekuláris Biológiai Tanszék összes jelenlegi és volt munkatársának, hogy szakmai és személyes támogatásukkal segítették munkámat. Külön köszönöm Gáspár Renátának, Kristó Ildikónak, Csebella-Bakota Adriennek és Pataki Edinának a kísérletekben nyújtott segítségüket és barátságukat.

Végül köszönöm Matusek Norbertnek és családom minden tagjának a biztatást és a támogatást. 


\section{Irodalomjegyzék}

1. Kornberg RD: Chromatin structure: a repeating unit of histones and DNA. Science 1974, 184(4139):868-871.

2. Peterson CL, Laniel MA: Histones and histone modifications. Curr Biol 2004, 14(14):R546-551.

3. Cockerill PN: Structure and function of active chromatin and DNase I hypersensitive sites. FEBS J, 278(13):2182-2210.

4. W. H. Freeman Pierce B: Genetics: A Conceptual Approach, 2nd edn: New York: W. H. Freeman and Company; 2005.

5. Richmond TJ, Finch JT, Rushton B, Rhodes D, Klug A: Structure of the nucleosome core particle at 7 A resolution. Nature 1984, 311(5986):532-537.

6. Luger K, Mader AW, Richmond RK, Sargent DF, Richmond TJ: Crystal structure of the nucleosome core particle at 2.8 A resolution. Nature 1997, 389(6648):251-260.

7. Turner BM: Chromatin and Gene Regulation: Blackwell Science Ltd 2001.

8. Zheng C, Hayes JJ: Structures and interactions of the core histone tail domains. Biopolymers 2003, 68(4):539-546.

9. Xiao T, Kao CF, Krogan NJ, Sun ZW, Greenblatt JF, Osley MA, Strahl BD: Histone H2B ubiquitylation is associated with elongating RNA polymerase II. Mol Cell Biol 2005, 25(2):637-651.

10. Kouzarides T: SnapShot: Histone-modifying enzymes. Cell 2007, 131(4):822.

11. Kouzarides T: Chromatin modifications and their function. Cell 2007, 128(4):693705.

12. Mutskov V, Gerber D, Angelov D, Ausio J, Workman J, Dimitrov S: Persistent interactions of core histone tails with nucleosomal DNA following acetylation and transcription factor binding. Mol Cell Biol 1998, 18(11):6293-6304.

13. Shahbazian MD, Grunstein M: Functions of site-specific histone acetylation and deacetylation. Annu Rev Biochem 2007, 76:75-100.

14. Henikoff S: Histone modifications: combinatorial complexity or cumulative simplicity? Proc Natl Acad Sci U S A 2005, 102(15):5308-5309.

15. Jacobson RH, Ladurner AG, King DS, Tjian R: Structure and function of a human TAFII250 double bromodomain module. Science 2000, 288(5470):1422-1425.

16. Lo WS, Trievel RC, Rojas JR, Duggan L, Hsu JY, Allis CD, Marmorstein R, Berger SL: Phosphorylation of serine 10 in histone $\mathrm{H3}$ is functionally linked in vitro and in vivo to Gcn5-mediated acetylation at lysine 14. Mol Cell 2000, 5(6):917-926.

17. Daujat S, Bauer UM, Shah V, Turner B, Berger S, Kouzarides T: Crosstalk between CARM1 methylation and CBP acetylation on histone H3. Curr Biol 2002, 12(24):2090-2097.

18. Dover J, Schneider J, Tawiah-Boateng MA, Wood A, Dean K, Johnston M, Shilatifard A: Methylation of histone $\mathrm{H} 3$ by COMPASS requires ubiquitination of histone H2B by Rad6. J Biol Chem 2002, 277(32):28368-28371.

19. Strahl BD, Allis CD: The language of covalent histone modifications. Nature 2000, 403(6765):41-45.

20. Jenuwein T, Allis CD: Translating the histone code. Science 2001, 293(5532):10741080.

21. Kouzarides T BS: Epigenetics: CSHL Press; 2006.

22. Nowak SJ, Corces VG: Phosphorylation of histone H3: a balancing act between chromosome condensation and transcriptional activation. Trends Genet 2004, 20(4):214-220. 
23. Jasencakova $\mathrm{Z}$, Groth A: Restoring chromatin after replication: how new and old histone marks come together. Semin Cell Dev Biol, 21(2):231-237.

24. $\mathrm{Xu} \mathrm{F}$, Zhang $\mathrm{K}$, Grunstein $\mathrm{M}$ : Acetylation in histone $\mathbf{H 3}$ globular domain regulates gene expression in yeast. Cell 2005, 121(3):375-385.

25. Hassan AH, Prochasson P, Neely KE, Galasinski SC, Chandy M, Carrozza MJ, Workman JL: Function and selectivity of bromodomains in anchoring chromatinmodifying complexes to promoter nucleosomes. Cell 2002, 111(3):369-379.

26. de la Cruz X, Lois S, Sanchez-Molina S, Martinez-Balbas MA: Do protein motifs read the histone code? Bioessays 2005, 27(2):164-175.

27. Grune T, Brzeski J, Eberharter A, Clapier CR, Corona DF, Becker PB, Muller CW: Crystal structure and functional analysis of a nucleosome recognition module of the remodeling factor ISWI. Mol Cell 2003, 12(2):449-460.

28. Brownell JE, Zhou J, Ranalli T, Kobayashi R, Edmondson DG, Roth SY, Allis CD: Tetrahymena histone acetyltransferase A: a homolog to yeast Gcn5p linking histone acetylation to gene activation. Cell 1996, 84(6):843-851.

29. Taunton J, Hassig CA, Schreiber SL: A mammalian histone deacetylase related to the yeast transcriptional regulator Rpd3p. Science 1996, 272(5260):408-411.

30. Roth SY, Denu JM, Allis CD: Histone acetyltransferases. Annu Rev Biochem 2001, 70:81-120.

31. Vogelauer M, Wu J, Suka N, Grunstein M: Global histone acetylation and deacetylation in yeast. Nature 2000, 408(6811):495-498.

32. Imoberdorf RM, Topalidou I, Strubin M: A role for gen5-mediated global histone acetylation in transcriptional regulation. Mol Cell Biol 2006, 26(5):1610-1616.

33. Gregory PD, Schmid A, Zavari M, Munsterkotter M, Horz W: Chromatin remodelling at the PHO8 promoter requires SWI-SNF and SAGA at a step subsequent to activator binding. EMBO $J$ 1999, 18(22):6407-6414.

34. Nourani A, Utley RT, Allard S, Cote J: Recruitment of the NuA4 complex poises the PHO5 promoter for chromatin remodeling and activation. EMBO J 2004, 23(13):2597-2607.

35. Wang A, Kurdistani SK, Grunstein M: Requirement of Hos2 histone deacetylase for gene activity in yeast. Science 2002, 298(5597):1412-1414.

36. De Nadal E, Zapater M, Alepuz PM, Sumoy L, Mas G, Posas F: The MAPK Hog1 recruits Rpd3 histone deacetylase to activate osmoresponsive genes. Nature 2004, 427(6972):370-374.

37. Grant PA, Berger SL: Histone acetyltransferase complexes. Semin Cell Dev Biol 1999, 10(2):169-177.

38. Lee KK, Workman JL: Histone acetyltransferase complexes: one size doesn't fit all. Nat Rev Mol Cell Biol 2007, 8(4):284-295.

39. Carrozza MJ, Utley RT, Workman JL, Cote J: The diverse functions of histone acetyltransferase complexes. Trends Genet 2003, 19(6):321-329.

40. Dyda F, Klein DC, Hickman AB: GCN5-related N-acetyltransferases: a structural overview. Annu Rev Biophys Biomol Struct 2000, 29:81-103.

41. Marmorstein R, Trievel RC: Histone modifying enzymes: structures, mechanisms, and specificities. Biochim Biophys Acta 2009, 1789(1):58-68.

42. Smith ER, Belote JM, Schiltz RL, Yang XJ, Moore PA, Berger SL, Nakatani Y, Allis CD: Cloning of Drosophila GCN5: conserved features among metazoan GCN5 family members. Nucleic Acids Res 1998, 26(12):2948-2954.

43. Candau R, Berger SL: Structural and functional analysis of yeast putative adaptors. Evidence for an adaptor complex in vivo. J Biol Chem 1996, 271(9):5237-5245. 
44. Carre $\mathrm{C}$, Szymczak D, Pidoux $\mathrm{J}$, Antoniewski $\mathrm{C}$ : The histone $\mathbf{H 3}$ acetylase dGcn5 is a key player in Drosophila melanogaster metamorphosis. Mol Cell Biol 2005, 25(18):8228-8238.

45. Grant PA, Duggan L, Cote J, Roberts SM, Brownell JE, Candau R, Ohba R, OwenHughes T, Allis CD, Winston F et al: Yeast Gen5 functions in two multisubunit complexes to acetylate nucleosomal histones: characterization of an Ada complex and the SAGA (Spt/Ada) complex. Genes Dev 1997, 11(13):1640-1650.

46. Grant PA, Eberharter A, John S, Cook RG, Turner BM, Workman JL: Expanded lysine acetylation specificity of Gen5 in native complexes. J Biol Chem 1999, 274(9):5895-5900.

47. Balasubramanian R, Pray-Grant MG, Selleck W, Grant PA, Tan S: Role of the Ada2 and Ada3 transcriptional coactivators in histone acetylation. J Biol Chem 2002, 277(10):7989-7995.

48. Lee KK, Sardiu ME, Swanson SK, Gilmore JM, Torok M, Grant PA, Florens L, Workman JL, Washburn MP: Combinatorial depletion analysis to assemble the network architecture of the SAGA and ADA chromatin remodeling complexes. Mol Syst Biol, 7:503.

49. Daniel JA, Grant PA: Multi-tasking on chromatin with the SAGA coactivator complexes. Mutat Res 2007, 618(1-2):135-148.

50. Baker SP, Grant PA: The SAGA continues: expanding the cellular role of a transcriptional co-activator complex. Oncogene 2007, 26(37):5329-5340.

51. Koutelou E, Hirsch CL, Dent SY: Multiple faces of the SAGA complex. Curr Opin Cell Biol, 22(3):374-382.

52. Friedrich B, Quensel C, Sommer T, Hartmann E, Kohler M: Nuclear localization signal and protein context both mediate importin alpha specificity of nuclear import substrates. Mol Cell Biol 2006, 26(23):8697-8709.

53. Kohler A, Schneider M, Cabal GG, Nehrbass U, Hurt E: Yeast Ataxin-7 links histone deubiquitination with gene gating and mRNA export. Nat Cell Biol 2008, 10(6):707-715.

54. Candau R, Moore PA, Wang L, Barlev N, Ying CY, Rosen CA, Berger SL: Identification of human proteins functionally conserved with the yeast putative adaptors ADA2 and GCN5. Mol Cell Biol 1996, 16(2):593-602.

55. Barlev NA, Candau R, Wang L, Darpino P, Silverman N, Berger SL:

Characterization of physical interactions of the putative transcriptional adaptor, ADA2, with acidic activation domains and TATA-binding protein. $J$ Biol Chem 1995, 270(33):19337-19344.

56. Sterner DE, Wang X, Bloom MH, Simon GM, Berger SL: The SANT domain of Ada2 is required for normal acetylation of histones by the yeast SAGA complex. J Biol Chem 2002, 277(10):8178-8186.

57. Gangloff YG, Romier C, Thuault S, Werten S, Davidson I: The histone fold is a key structural motif of transcription factor TFIID. Trends Biochem Sci 2001, 26(4):250-257.

58. Muratoglu S, Georgieva S, Papai G, Scheer E, Enunlu I, Komonyi O, Cserpan I, Lebedeva L, Nabirochkina E, Udvardy A et al: Two different Drosophila ADA2 homologues are present in distinct GCN5 histone acetyltransferase-containing complexes. Mol Cell Biol 2003, 23(1):306-321.

59. Kusch T, Guelman S, Abmayr SM, Workman JL: Two Drosophila Ada2 homologues function in different multiprotein complexes. Mol Cell Biol 2003, 23(9):3305-3319. 
60. Stockinger EJ, Mao Y, Regier MK, Triezenberg SJ, Thomashow MF:

Transcriptional adaptor and histone acetyltransferase proteins in Arabidopsis and their interactions with CBF1, a transcriptional activator involved in coldregulated gene expression. Nucleic Acids Res 2001, 29(7):1524-1533.

61. Guelman S, Suganuma T, Florens L, Swanson SK, Kiesecker CL, Kusch T, Anderson S, Yates JR, 3rd, Washburn MP, Abmayr SM et al: Host cell factor and an uncharacterized SANT domain protein are stable components of ATAC, a novel dAda2A/dGcn5-containing histone acetyltransferase complex in Drosophila. Mol Cell Biol 2006, 26(3):871-882.

62. Suganuma T, Gutierrez JL, Li B, Florens L, Swanson SK, Washburn MP, Abmayr SM, Workman JL: ATAC is a double histone acetyltransferase complex that stimulates nucleosome sliding. Nat Struct Mol Biol 2008, 15(4):364-372.

63. Nagy Z, Riss A, Fujiyama S, Krebs A, Orpinell M, Jansen P, Cohen A, Stunnenberg HG, Kato S, Tora L: The metazoan ATAC and SAGA coactivator HAT complexes regulate different sets of inducible target genes. Cell Mol Life Sci, 67(4):611-628.

64. Guelman S, Suganuma T, Florens L, Weake V, Swanson SK, Washburn MP, Abmayr SM, Workman JL: The essential gene wda encodes a WD40 repeat subunit of Drosophila SAGA required for histone $\mathbf{H 3}$ acetylation. Mol Cell Biol 2006, 26(19):7178-7189.

65. Weake VM, Swanson SK, Mushegian A, Florens L, Washburn MP, Abmayr SM, Workman JL: A novel histone fold domain-containing protein that replaces TAF6 in Drosophila SAGA is required for SAGA-dependent gene expression. Genes Dev 2009, 23(24):2818-2823.

66. Myster SH, Wang F, Cavallo R, Christian W, Bhotika S, Anderson CT, Peifer M: Genetic and bioinformatic analysis of $41 \mathrm{C}$ and the $2 \mathrm{R}$ heterochromatin of Drosophila melanogaster: a window on the heterochromatin-euchromatin junction. Genetics 2004, 166(2):807-822.

67. Kurshakova MM, Krasnov AN, Kopytova DV, Shidlovskii YV, Nikolenko JV, Nabirochkina EN, Spehner D, Schultz P, Tora L, Georgieva SG: SAGA and a novel Drosophila export complex anchor efficient transcription and mRNA export to NPC. EMBO J 2007, 26(24):4956-4965.

68. Weake VM, Lee KK, Guelman S, Lin CH, Seidel C, Abmayr SM, Workman JL: SAGA-mediated H2B deubiquitination controls the development of neuronal connectivity in the Drosophila visual system. EMBO J 2008, 27(2):394-405.

69. Spedale G, Timmers HT, Pijnappel WW: ATAC-king the complexity of SAGA during evolution. Genes Dev, 26(6):527-541.

70. Ciurciu A, Komonyi O, Pankotai T, Boros IM: The Drosophila histone acetyltransferase Gen5 and transcriptional adaptor Ada2a are involved in nucleosomal histone H4 acetylation. Mol Cell Biol 2006, 26(24):9413-9423.

71. Grau B, Popescu C, Torroja L, Ortuno-Sahagun D, Boros I, Ferrus A: Transcriptional adaptor ADA3 of Drosophila melanogaster is required for histone modification, position effect variegation, and transcription. $\mathrm{Mol} \mathrm{Cell} \mathrm{Biol}$ 2008, 28(1):376-385.

72. Pankotai T, Komonyi O, Bodai L, Ujfaludi Z, Muratoglu S, Ciurciu A, Tora L, Szabad J, Boros I: The homologous Drosophila transcriptional adaptors ADA2a and ADA2b are both required for normal development but have different functions. Mol Cell Biol 2005, 25(18):8215-8227.

73. Qi D, Larsson J, Mannervik M: Drosophila Ada2b is required for viability and normal histone $\mathbf{H 3}$ acetylation. Mol Cell Biol 2004, 24(18):8080-8089. 
74. Gamper AM, Kim J, Roeder RG: The STAGA subunit ADA2b is an important regulator of human GCN5 catalysis. Mol Cell Biol 2009, 29(1):266-280.

75. Aravind L, Iyer LM: The SWIRM domain: a conserved module found in chromosomal proteins points to novel chromatin-modifying activities. Genome Biol 2002, 3(8):RESEARCH0039.

76. Da G, Lenkart J, Zhao K, Shiekhattar R, Cairns BR, Marmorstein R: Structure and function of the SWIRM domain, a conserved protein module found in chromatin regulatory complexes. Proc Natl Acad Sci U S A 2006, 103(7):2057-2062.

77. Eden E, Navon R, Steinfeld I, Lipson D, Yakhini Z: GOrilla: a tool for discovery and visualization of enriched GO terms in ranked gene lists. BMC Bioinformatics 2009, 10:48.

78. Hebbes TR, Clayton AL, Thorne AW, Crane-Robinson C: Core histone hyperacetylation co-maps with generalized DNase I sensitivity in the chicken beta-globin chromosomal domain. EMBO J 1994, 13(8):1823-1830.

79. Braunstein M, Rose AB, Holmes SG, Allis CD, Broach JR: Transcriptional silencing in yeast is associated with reduced nucleosome acetylation. Genes Dev 1993, 7(4):592-604.

80. Pokholok DK, Harbison CT, Levine S, Cole M, Hannett NM, Lee TI, Bell GW, Walker K, Rolfe PA, Herbolsheimer E et al: Genome-wide map of nucleosome acetylation and methylation in yeast. Cell 2005, 122(4):517-527.

81. Yan C, Boyd DD: Histone $\mathbf{H 3}$ acetylation and $\mathbf{H 3} \mathbf{K 4}$ methylation define distinct chromatin regions permissive for transgene expression. Mol Cell Biol 2006, 26(17):6357-6371.

82. Wang T, Kobayashi T, Takimoto R, Denes AE, Snyder EL, el-Deiry WS, Brachmann RK: hADA3 is required for p53 activity. EMBO J 2001, 20(22):6404-6413.

83. Ollmann M, Young LM, Di Como CJ, Karim F, Belvin M, Robertson S, Whittaker K, Demsky M, Fisher WW, Buchman A et al: Drosophila p53 is a structural and functional homolog of the tumor suppressor p53. Cell 2000, 101(1):91-101.

84. Goto SG: A novel gene that is up-regulated during recovery from cold shock in Drosophila melanogaster. Gene 2001, 270(1-2):259-264.

85. Zsindely N, Pankotai T, Ujfaludi Z, Lakatos D, Komonyi O, Bodai L, Tora L, Boros IM: The loss of histone $\mathrm{H3}$ lysine 9 acetylation due to dSAGA-specific dAda2b mutation influences the expression of only a small subset of genes. Nucleic Acids Res 2009, 37(20):6665-6680.

86. Silverman N, Agapite J, Guarente L: Yeast ADA2 protein binds to the VP16 protein activation domain and activates transcription. Proc Natl Acad Sci U S A 1994, 91(24):11665-11668.

87. Huisinga KL, Pugh BF: A genome-wide housekeeping role for TFIID and a highly regulated stress-related role for SAGA in Saccharomyces cerevisiae. Mol Cell 2004, 13(4):573-585.

88. Vlachonasios KE, Thomashow MF, Triezenberg SJ: Disruption mutations of ADA2b and GCN5 transcriptional adaptor genes dramatically affect Arabidopsis growth, development, and gene expression. Plant Cell 2003, 15(3):626-638.

89. Bernstein BE, Tong JK, Schreiber SL: Genomewide studies of histone deacetylase function in yeast. Proc Natl Acad Sci U S A 2000, 97(25):13708-13713.

90. Kaldis A, Tsementzi D, Tanriverdi O, Vlachonasios KE: Arabidopsis thaliana transcriptional co-activators ADA2b and SGF29a are implicated in salt stress responses. Planta, 233(4):749-762. 
91. Nagy Z, Tora L: Distinct GCN5/PCAF-containing complexes function as coactivators and are involved in transcription factor and global histone acetylation. Oncogene 2007, 26(37):5341-5357.

92. Robert F, Pokholok DK, Hannett NM, Rinaldi NJ, Chandy M, Rolfe A, Workman JL, Gifford DK, Young RA: Global position and recruitment of HATs and HDACs in the yeast genome. Mol Cell 2004, 16(2):199-209.

93. Johnsson AE, Wright AP: The role of specific HAT-HDAC interactions in transcriptional elongation. Cell Cycle, 9(3):467-471.

94. Weake VM, Dyer JO, Seidel C, Box A, Swanson SK, Peak A, Florens L, Washburn MP, Abmayr SM, Workman JL: Post-transcription initiation function of the ubiquitous SAGA complex in tissue-specific gene activation. Genes Dev, 25(14):1499-1509.

95. Roh TY, Ngau WC, Cui K, Landsman D, Zhao K: High-resolution genome-wide mapping of histone modifications. Nat Biotechnol 2004, 22(8):1013-1016.

96. Kurdistani SK, Grunstein M: Histone acetylation and deacetylation in yeast. Nat Rev Mol Cell Biol 2003, 4(4):276-284. 


\section{A doktori értekezés összefoglalója}

Az eukarióta sejtek müködéséhez nélkülözhetetlen a genom nagymértékü, ugyanakkor dinamikus összetömörítése. Ezt a különböző fehérje faktorok közremüködésével létrejövő kromatinszerkezet biztosítja, amely alapegységeit a hiszton $(\mathrm{H} 2 \mathrm{~A}, \mathrm{H} 2 \mathrm{~B}, \mathrm{H} 3, \mathrm{H} 4)$ fehérjékre feltekeredő 147 bázispárnyi DNS-ből felépülő nukleoszómák alkotják. A tömörödés különböző szintjei eltérő mértékü hozzáférhetést biztosítanak a DNS szálon lezajló folyamatokat (transzkripció, DNS replikáció és hibajavítás) végző faktorok számára. Így a kromatinszerkezet tömörsége, illetve annak dinamikus átalakítását végző mechanizmusok fontos szabályozó szerepet töltenek be a transzkripció folyamata során. A kromatinszerkezet dinamikus átalakításáért felelős mechanizmusok egyike a nukleoszómális hiszton fehérjéken megjelenő poszttranszlációs módosítások. Az egyik, intenzíven tanulmányozott ilyen módosítás a hiszton fehérjék acetilációja. A nukleoszómák hiperacetilált állapota egy nyitottabb, míg a hipoacetilált nukleoszómák egy tömörebb kromatinszerkezettel hozhatók összefüggésbe. Számos megfigyelés alapján az aktív transzkripció folyamatához egy hiperacetilált, nyitott kormatin szerkezet köthető, viszont az acetiláció szabályozó szerepének pontos részletei még kevésbé ismertek. Ezek felderítéséhez nagymértékben hozzájárulnak a hiszton acetiltranszferáz (HAT) enzimek vizsgálata során nyert információk. Az egyik legjobban jellemzett HAT aktivitású fehérje a Gcn5, amely több alegységes fehérje komplex tagjaként látja el acetilációs funkcióját. A Gcn5-tartalmú HAT komplexek ADA-típusú adaptor fehérjéket is tartalmaznak, amelyek a Gcn5 fehérje aktivitásának és specificitásának meghatározásában játszanak szerepet. A Drosophila melanogaster-ben előforduló egyik Gcn5-tartalmú HAT komplex, a dSAGA acetilációs moduljának egyik alegysége a dADA2b fehérje, amely szükséges a komplex H3 hiszton 9-es és 14-es lizinjére specifikus acetilációs aktivitásához. Az ADA2 fehérjék sokszínü funkciójára utal, hogy a Drosophila Ada2b génről több mRNS és fehérje izoforma termelődik. A két dADA2b fehérje izoforma N-terminális régiója azonos, mindkettő tartalmaz egy-egy, az ADA2 fehérjékre jellemző ZZ cink-ujj és SANT domént, viszont a C-terminális régió eltérő. Itt, az ADA2 fehérjékre specifikus ADA motívumból a rövidebb izoformában (dADA2bS) csak kettő, míg a hosszabb izoformában (dADA2bL) három darab található meg. Mivel ezeknek az ADA motívumoknak feltételezhetően az ADA2 fehérjék más komplex alegységekkel kialakított kölcsönhatásaik létrejöttében fontos szerepe lehet, az eltérő számú ADA motívumot tartalmazó dADA2b izoformák más folyamatok szabályozásában betöltött szerepét feltételezhetjük. 
A dolgozatomban a teljes dADA2b funkciót eltávolító (dAda2 $\left.b^{842}\right)$ deléció, valamint a rövid dADA2bS izoformát kifejező transzgenikus törzsek alkalmazásával megvizsgáltam, hogy a dADA2b fehérjéken keresztül a dSAGA acetilációs aktivitása hogyan járul hozzá a génmüködés szabályozásához.

\section{A dSAGA acetiltranszferáz komplex szabályozása alatt álló gének}

Először meghatároztuk, hogy adott fejlődési állapotokban mely gének expresszióját szabályozza a dSAGA specifikus acetiláció. Ehhez vad típusú és $d A d a 2 b$ mutáns egyedeken két fejlődési állapotban (késői L3 lárva és korai báb állapot) teljes transzkriptum analízist végeztünk. Összehasonlítva a génexpressziós profilokat meghatároztuk, hogy a dADA2b fehérje hiányában mely gének expressziója tér el a vad típusétól. A dSAGA komplex mindkét fejlődési állapotban a gének csak egy kis részének (kb. $5 \%$ ) a szabályozásában vesz részt. Az acetiláció szerepéről eddig kialakított képtől eltérően ezen dSAGA-függő géneknek több mint a fele nem csökkent, hanem emelkedett mértékü expressziót mutatott a dSAGA specifikus acetiláció hiányában. Ehhez hasonlóan a szakirodalomban más magasabbrendü organizmus esetében (Arabidopsis thaliana) is azt találták, hogy az AtGcn5 és AtAda2b transzkripciós koaktivátorok hiányában a gének egy részének megemelkedett az expressziója. Mind a két vizsgált fejlődési állapotban hasonló funkcióval rendelkező gének mutattak dADA2b-függő expressziót. A dADA2b fehérje stresszválasz szabályozásában betöltött funkciójára utalhat, hogy az emelkedett expressziójú gének között nagy számban találunk az immunfunkcióknak valamint a mikroorganizmusok elleni védekezési folyamtoknak megfelelő génontológiai csoportokba tartozó géneket.

\section{A dSAGA komplexre specifikus dADA2b alegység rövid izoformájának szerepe a dSAGA müködésében}

Előzetes kísérleti adatok azt mutatták, hogy a dAda2b génről kétféle mRNS és fehérje izoforma képződik, így megvizsgáltuk, hogy a dSAGA komplexre specifikus dADA2b alegység ezen két izoformája hogyan járul hozzá a dSAGA génmüködés szabályozásában betöltött funkciójához. A kétféle mRNS formának megfelelő fehérje izoformák változó mennyiségben ugyan, de az egyedfejlődés minden szakaszában jelen voltak. Ezért megvizsgáltuk, hogy a dADA2b rövid izoforma önmagában hogyan képes ellátni a teljes dADA2b funkciót. Mind a dAda2b deléció okozta letalitás tekintetében, mind a dSAGA komplex acetilációs aktivitását, mind az apoptotikus folyamatok szabályozására kifejtett hatását tekintve a rövid dADA2b fehérje csak részlegesen tudta pótolni a dADA2b funkciót. Összességében elmondhatjuk, hogy a két dADA2b izoforma csak a C-terminálison elhelyezkedő harmadik ADA motívum jelenlétében különbözik egymástól, funkcionálisan 
mégsem ekvivalensek. A dADA2bS esetében tapasztalt részleges funkció hátterében azt feltételezhettük, hogy a rövid izoforma jelenlétében létrejövő dSAGA komplex csak az egyik irányú génexpressziós változások szabályozásában képes részt venni. Ezért a dADA2bS izoformát kifejező, egyébként $d A d a 2 b$ mutáns lárvákon transzkriptum analízist végeztünk, amely során megállapítottuk, a dADA2bS fehérje jelenlétében létrejövő dSAGA komplex mind az emelkedett, mind a csökkent expressziójú gének szabályozásában részt vesz. Az emelkedett expressziót mutató gének 40\%-ának az expresszióját visszaállította a vad típusban mért szintre, tehát megállapíthatjuk, hogy a represszió közvetítésében hatékonyabbnak bizonyult a rövid izoforma, viszont itt sem volt képes betölteni a teljes $d A d a 2 b$ funkciót. A dADA2b-függő gének több, mint felének szabályozásához a rövid izoforma önmagában nem volt elegendő, ezen gének megfelelő átírásához valószínűleg a dADA2bL fehérjére, vagy mindkét izoforma egyidejü jelenlétére szükség lehet. Elképzelhető, hogy a dSAGA komplex a dADA2b izoformák segítségével valósít meg egy génspecifikus transzkripciós szabályozást, de ez nem olyan formában történik, hogy a rövid izoforma jelenlétében a dSAGA komplex kizárólag aktiváló, vagy represszáló hatást lenne képes kifejteni.

A dSAGA komplex és az általa létrehozott H3K9 acetiláció szerepe a génexpresszió szabályozásában

A dADA2b fehérje a dSAGA komplex hiszton acetilációt létrehozó moduljának egyik felépítő eleme, amely meghatározza a dGen5 fehérje szubsztrát specificitását. Így megvizsgáltuk, hogy a dADA2b fehérjék hiányában megfigyelt expressziós változások közül mind a csökkent, mind pedig az emelkedett mértékü génexpresszió is a dADA2b acetilációt befolyásoló hatásához köthető-e. Ehhez $w^{1118}$ és dAda2b mutáns SpEv lárvákon végzett kromatin immunprecipitációs kísérletekben dSAGA-függő (emelkedett és csökkent expresszió), illetve dSAGA-független transzkripciót mutató géneken is meghatároztuk a dADA2b fehérje jelenlétét, valamint a H3K9 acetiláció szintjét.

A dADA2b fehérje kötődése alapján több dSAGA-függő expressziót mutató gént (sug, cnc, $C y c B, H u s 1)$ is direkt dSAGA célgénként sikerült azonosítani. Mind a csökkent, mind az emelkedett expressziót mutató gének esetében is sikerült dADA2b kötődést kimutatnunk, tehát mindkét irányú expressziós változás hátterében a dSAGA komplex közvetlen müködése állhat. A dADA2b fehérje jelenléte nemcsak a gének promóterhez közeli részén, hanem a 3' végi régiójában is kimutatható volt. Ezekhez az adatokhoz hasonlóan a Schizosaccharomyces pombe yGcn5 fehérje bizonyos gének esetében nem csak a promóterhez közeli, hanem a teljes átírt régiókhoz is kapcsolódott, valamint Drosophila embrionális izom sejtekben is több gén esetében a promóterhez közeli szakaszok mellett a 3' végi régiókban is kimutatható volt a 
dADA2b fehérje jelenléte. Az általunk kimutatott dADA2b kötődési mintázat hátterében az állhat, hogy a dSAGA komplex nem csak a transzkripció iniciációs, hanem elongációs lépését is szabályozhatja, és így a gének teljes átírt régióján megjelenik a dSAGA komplex.

A dSAGA-függő expressziót mutató gének H3K9 acetilációs szintjét megvizsgálva azt tapasztaltuk, hogy mind a csökkent (sug, cnc, CycB), mind az emelkedett (Fst, Hus1, AttD) expressziójú gének területén megjelent a dSAGA specifikus H3K9 acetiláció. Élesztő és Drosophila sejtekből származó adatokhoz hasonlóan az általunk vizsgált dSAGA specifikus H3K9 acetiláció is a vizsgált gének promóterhez közeli régióján jelent meg magasabb szinten. Ezen adatok alapján megállapíthatjuk, hogy a promóterhez közeli régióban a dSAGA specifikus H3K9 acetiláció jelenléte számos gén szabályozása során esszenciális, viszont a transzkripció folyamata során nem csak aktiváló, hanem represszáló hatás kialakításához is közvetlenül hozzájárulhat.

\section{A dSAGA specifikus H3K9 acetiláció szerepe a génaktiváció folyamatában}

Hogy megtudjuk, a dSAGA specifikus H3K9 acetiláció hogyan járul hozzá a génaktiváció folyamatához, feltérképeztük a génaktiváció során az acetiláció szintjét, valamint annak az adott gén transzkripciójára kifejtett hatását is. A nyálmirigy óriáskromoszómákon elvégzett immunfestés során megállapítottuk, hogy a dSAGA specifikus hiszton acetiláció nem kizárólagos előfeltétele a hősokk gének aktivációjának, ugyanis az átírást végző RNS polimeráz csökkent $\mathrm{H} 3 \mathrm{~K} 9$ acetiláció mellett is képes az aktivált hősokk génekhez kötődni. Az acetiláció szerepének részletesebb tanulmányozásához az ekdizon hormon által indukált Eip74EF és Eip75B korai gének vizsgálatát választottuk eszköznek. Először feltérképeztük ezen gének aktivációs profiljait, majd az ezek alapján a génaktivációt kísérő acetilációs mintázat vizsgálatához kiválasztottunk egy indukció előtti és két indukció alatti időpontot. Ezekben az időpontokban kromatin immunprecipitációs kísérlettel meghatároztuk a H3K9 acetiláció mennyiségét a gének promóter, promóterhez közeli intronikus, valamint 3' véghez közeli exonikus régióiban. Az elvégzett ChIP kísérlet eredménye azt sugallja, hogy a H3K9 acetiláció a vizsgált régiókban egy általánosan jelen lévő hiszton módosítás, ami nem mutat kifejezett régió specificitást. A génaktiváció folyamatával kapcsolatban sem tapasztaltunk olyan jellegü összefüggést, hogy csak az adott transzkriptum expressziója idején jelenne meg ez a módosítás. Egyedül az adott promóterek müködésének megfelelően a promóterekhez közeli régiókban mutatott enyhe emelkedést a H3K9 acetiláció mennyisége. dAda2b mutáns vándorló L3 stádiumú lárvákon (wL3) elvégzett kromatin immunprecipitációs kísérletekből megállapítottuk, hogy a dADA2b hiányában a H3K9 acetiláció szintje az általunk vizsgált összes génszakaszon és intergenikus régióban 
lecsökkent. Tehát a dSAGA komplex az Eip74EF és Eip75B gének esetében nemcsak a promótereken előforduló, hanem egy általánosan jelen lévő H3K9 acetilációs mintázat létrehozásáért felelős. Már az élesztő yGcn5 fehérjéről is leírtak egy ehhez hasonló, nagyobb kiterjedésü, kódoló és intergenikus területeket egyaránt érintő általános acetilácós aktivitást.

Megvizsgáltuk, hogy ez a dSAGA specifikus általános acetilációs mintázat hozzájárule az Eip74EF és Eip75B gének expressziójának szabályozásához, melyhez megmértük a dADA2b fehérjék hiányában az Eip74EF és Eip75B gének promótereiről képződő nascens RNS-ek mennyiségét. Ennek során megállapítottuk, hogy a kisebb mértékben aktiválódó Eip74EF-RB és Eip75B-RC promóterek indukciója a dSAGA specifikus H3K9 acetiláció hiányában csak kevésbé sérül, míg az erőteljes indukciót mutató Eip74EF-RA promóter aktivációja elmarad. Tehát az Eip74EF és Eip75B gének területén általánosan jelen lévő dSAGA specifikus H3K9 acetilációs mintázat fontos szabályozó szereppel bír ezen gének aktivációjának szabályozásában. Ezek az adatok is alátámasztják azt a tényt, hogy az eukromatikus régiókban általánosan jelen lévő acetilációs mintázat hozzájárulhat a génműködés megfelelő kinetikájához, és ezáltal fontos szerepet tölt be a génexpresszió szabályozásában.

\section{A dSAGA specifikus hiszton acetiláció feltételezett funkciója a génmüködés}

\section{szabályozásában}

A dolgozatomban részletezett eredmények is rámutatnak, hogy a dSAGA HAT komplex rendkívül összetett módon járulhat hozzá a génműködés szabályozásához. Egyrészt transzkripciót szabályozó fehérjékkel közvetlenül kölcsönhatva szerepet játszhat egy irányított, helyspecifikusan megjelenő acetiláció létrehozásában, másrészt részt vesz egy általánosan megjelenő acetilációs alapmintázat fenntartásában is. Ez a kétféle acetiláció nem egymástól függetlenül jelentkezik, hanem egy dinamikusan változó acetilációs háttéren jelenhet meg egy irányított, helyspecifikus acetiláció. Az elvégzett kromatin immunprecipitációs kísérletben láthattuk, hogy a dSAGA elégtelen müködése következtében sérült az eukromatikus részek általános H3K9 acetilációs mintázata. Elképzelhető, hogy ennél az alacsonyabb acetiláltságú kromatinszerkezetnél gyengül a szabályozó fehérjék kromatinhoz való kötődési képessége, és ezáltal - attól függően, hogy aktivátor vagy represszor hatású fehérjéről van szó - módosul az általuk szabályozott gének müködése. Részben ez magyarázhatja, hogy a dSAGA specifikus acetiláció hiányában nem csak csökkent, hanem emelkedett expressziójú géneket is azonosítottunk. Ezenfelül ez az általánosan megjelenő, dinamikusan változó acetilációs mintázat hozzájárulhat a génszabályozás megfelelő kinetikájához is. Ezt igazolja, hogy az általunk használt in vivo 
modell géneken (Eip74EF és Eip75B) a dSAGA specifikus H3K9 acetiláció hiányában módosult a génaktiváció folyamata. Tehát elképzelhető, hogy a dSAGA specifikus általános H3K9 acetilációs mintázat hiányában bizonyos gének aktivációja nem a megfelelő időben történik meg, és ezáltal teljesen felborulhat a sejtre jellemző koordinált génexpressziós mintázat.

Tehát a dSAGA komplex acetilációs aktivitása közvetett módon is, egy transzkripciót megengedő kromatinszerkezet fenntartásán keresztül is hozzájárul a génmüködés szabályozásához. 


\section{Summary}

Considerable and dynamic compaction of the genome is essential for normal function of eukaryotic cells. This is carried out by the chromatin structure, in which 147 base pairs of DNA is wound around a core of four basic histone proteins (H2A, H2B, H3, H4) to form the basic building blocks, the nucleosomes. Individual nucleosomes can pack against each other and adopt several higher-order chromatin structures which are thought to be the major obstacles to transcription, replication and repair. Therefore, compaction level and dynamic changing of chromatin packaging can possess a major regulatory role in gene expression regulation. Posttranslational modifications of histone proteins are one of the various known mechanisms altering the accessibility of the chromatin template. Among several described modifications acetylation of lysine resuides is one of the most studied ones. Histone acetylation is a major determinant of chromatin compaction: hyperacetylation state is coupled to an open conformation, whereas hypoacetylated nucleosomes are characteristic for a compact, folded chromatin. Hyperacetylated, open chromatin has long been linked to active transcription; however, the exact details of its regulatory effect have not yet been established. Considerable knowledge provided from characterization of histone acetlytransferases (HAT) can contribute to better understanding the regulatory role of histone acetylation. One of the well characterized HAT enzymes is Gcn5, which functions as a subunit of large multiprotien complexes. These Gcn5-containing HAT complexes harbour ADA-type adaptor proteins, which regulate the template recognition and lysine specificity of Gcn5. dADA2b protein is a subunit of the acetylation modul of dSAGA, one of the two different Drosophila Gen5containing HAT complexes, that determines the histone H3 lysine 9 and 14 acetylation specificity of the complex. Diverse functions of ADA2 proteins are demonstrated by the fact $d A d a 2 b$ gene produces two mRNAs and protein forms. The N-terminal parts of dADA2b isoforms are identical; these shared parts harbor a zinc finger-like ZZ and a SANT domain, characteristic for all known ADA2 proteins. The isoforms differ in their C-terminal regions, which contain ADA2 protein specific $\alpha$-helical motifs so-called ADA boxes. The short isoform (dADA2bS) of dADA2b harbors two ADA boxes, while a third ADA box is present only in the longer isoform (dADA2bL). If these ADA boxes could contribute to the capability of ADA2 proteins to interact with other subunits of the complex, we hypothesized that the $\mathrm{dADA} 2 \mathrm{~b}$ isoforms varying in the number of the ADA boxes could function in different regulatory processes. 
In my thesis I examined the presumed role of dSAGA specific histone acetylation in gene regulation by utilizing a $d A d a 2 b^{842}$ deletion eliminating complete $\mathrm{dADA} 2 \mathrm{~b}$ function and dADA2bS isoform expressing transgenic strains.

\section{Genes are regulated by the dSAGA acetyltransferase complex}

We determined the genes regulated by dSAGA specific acetylation in well defined developmental stages. For this purpose, we performed transcriptome analysis on wild type and $d A d a 2 b$ mutant animals in two developmental stages (late L3 larvae and early pupa). By comparing the mRNA profiles we determined genes showing altered expression level in the absence of dADA2b. At both time points analyzed only a small subset of genes (5\%) were regulated by dSAGA complex. Despite the supposed role of histone acetylation in transcription activation, more than half of the dSAGA-dependent genes showed increased transcription levels in the absence of dSAGA specific acetylation. Similarly to our data, in higher eukaryotes (Arabidopsis thaliana) elimination of transcriptional coactivators AtGcn5 and AtAda2b also resulted in upregulation of more than half of the affected genes. In both analyzed developmental stages the dSAGA-regulated genes showed similar distribution according to biological function. The significant enrichment of the upregulated genes in gene ontology categories involved immune response, might suggest the potential role of dADA2b protein in stress response.

\section{Role of short isoform of dADA2b subunit in dSAGA functions}

Previous studies revealed that $d A d a 2 b$ gene gave rise to two mRNAs and protein isoforms (dADA2bS and dADA2bL). Therefore, we examined whether these two dSAGA specific dADA2b subunits could contribute to the functional complexity of dSAGA in transcription regulation. By western blot analysis we demonstrated that the dADA2b protein isoforms corresponding to the above mentioned mRNA forms could be detected during Drosophila development in various amount in different stages. Therefore we studied the potential of the short isoform to occupy the $d A d a 2 b$ function. We concluded that the dADA2b short isoform alone can partially provide the $d A d a 2 b$ function both in development, in acetylation activity and in the regulation of apoptotic processes. Taken together, the two $\mathrm{dADA} 2 \mathrm{~b}$ isoforms differ only in their C-terminus however functionally they are not equivalent. The partial functional rescue effect of dADA2bS can be explained by the fact the dADA2bS-containing dSAGA complex regulates the transcription of only the down- or only the upregulated dSAGA-dependent genes. In order to answer this question we performed transcriptom analysis on larvae expressing only the short dADA2b isoform in $d A d a 2 b$ mutant background. We concluded that the dADA2bS-containing dSAGA complex could contribute 
to the regulation of both the increased and the decreased ones of dSAGA-regulated genes but it was more effective in mediating of repressive function. Besides this, the presence of the short isoform alone was not sufficient for the proper regulation of more than the half of the dSAGA-dependent genes. Thus the normal expression of these genes might require the presence of either the long isoform or both dADA2b isoforms. Our data can not exclude the possibility that dSAGA could perform gene-selective transcription regulation by using distinct $\mathrm{dADA} 2 \mathrm{~b}$ isoforms however it is most probably not accomplished by the mechanism in which the dADA2bS-containing dSAGA induces or represses the expression of the regulated genes.

\section{The role of dSAGA complex and dSAGA specific H3K9 acetylation in regulation}

\section{of gene expression}

The dADA2b protein is a component of the acetylation module of dSAGA complex and determinates substrate specificity of dGen5. Therefore, we examined whether both the decreased and increased transcription in the absence of dADA2b can be the consequence of the role of dADA $2 b$ in histone acetylation. For this in $w^{1118}$ and $d A d a 2 b$ mutant SpEv larvae we determined the presence of dADA2b protein and the H3K9 acetylation level on dSAGAdependent (both up- and downregulated) and dSAGA-independent genes.

According to the presence of dADA2b protein more dSAGA-dependent genes (sug, cnc, СусB, Hus1) could be identified as direct dSAGA target genes. Both on up- and downregulated genes we could detect $\mathrm{dADA} 2 \mathrm{~b}$ binding so the dSAGA function could be directly responsible for either expression changes. The presence of $\mathrm{dADA} 2 \mathrm{~b}$ could be detected not only on promoters but also on 3' end regions. Similarly, the presence of Schizosaccharomyces pombe yGen5 on promoters, its binding to coding regions was also demonstrated on several genes. Moreover, in Drosophila embryonic muscle cells in case of several genes dADA2b was found on promoters and 3' end regions. Our data about dADA2b binding pattern suggests the possible role of dSAGA in transcription initiation and elongation phases.

By examining the H3K9 acetylation level of dSAGA-dependent genes we detected the presence of dSAGA specific H3K9 acetylation on both up- (Fst, Hus1, AttD) and downregulated (sug, $c n c, C y c B$ ) genes. Similarly to data from yeast and Drosophila cells, we also could detect higher levels of the H3K9 acetylation on promoters. Thus we concluded that the presence of the dSAGA specific acetylation on promoters is essential in the transcription regulation of several genes but it can contribute not only to gene activation but also to gene repression. 


\section{The function of dSAGA specific H3K9 acetylation in the process of gene}

$\underline{\text { activation }}$

To understand whether the dSAGA specific H3K9 acetylation can contribute to the process of gene activation, we determined the level of histone acetylation during the progress of gene activation and its effect on the efficiency of transcription. According to immunostaining of polythene chromosomes of salivary gland in Drosophila we established that the presence of dSAGA specific acetylation is not an obligate prerequisite of gene activation as the active RNA polymerase could bind to activated heat shock genes in the loss of dSAGA specific H3K9 acetylation. To clarify in details the role of acetylation during gene activation in vivo we used two early ecdysone induced genes (Eip74EF and Eip75B) as models. First we defined the activation patterns of these genes, therefore three time points were selected (one before activation, two during activation) for the analysis of the acetylation pattern. At these time points we determined the level of $\mathrm{H} 3 \mathrm{~K} 9$ acetylation on the promoter, on the first intronic and on the 3' end exonic regions of these genes by chromatin immunoprecipitation. Our results demonstrated that the H3K9 acetylation occurred globally on the tested genes, its regional and temporal distribution could not be detected. Only moderate increase in the $\mathrm{H} 3 \mathrm{~K} 9$ acetylation level but not obligate appearance of it was observable nearby the promoter regions during active transcription. Chromatin immunoprecipitaion analysis performed on $d A d a 2 b$ mutant wandering (wL3) larvae showed that the level of H3K9 acetylation decreased on all of the examined genes and intergenic regions in the absence of dADA2b. Therfore, the dSAGA complex is responsible for the establishment of a global H3K9 acetylation pattern on the Eip74EF and Eip75B genes. A similar global acetylation activity of yeast yGen5 on large ranging coding and intergenic regions was previously described.

To examine how this dSAGA specific global acetylation pattern could contribute to the transcription regulation of Eip74EF and Eip75B genes, we measured the level of nascent RNA produced from Eip74EF and Eip75B promoters in the absence of dADA2b proteins. We found that the induction of the moderately activated Eip74EF-RB and Eip75B-RC promoters did not change significantly, whereas the activation of the strongly induced Eip74EF-RA promoter failed to occur in the loss of dSAGA specific H3K9 acetylation. So the dSAGA specific global acetylation pattern on Eip74EF and Eip75B genes can play an important regulatory role in the activation of these genes. These data confirm that the global histone acetylation pattern in the euchromatic regions promotes proper kinetics of transcription thus has remarkable function in gene regulation. 


\section{The supposed function of dSAGA specific histone acetylation in gene regulation}

Previously detailed results in my thesis indicate the multiple role of dSAGA HAT complex in gene regulation. On one hand, interacting directly with transcription factors dSAGA functions in the generation of a site-specific acetylation, on the other hand it contributes to the establishment and maintenance of a global acetylation pattern. The two acetylation types do not occur independently, but on a dynamic global acetylation background a site-specific acetylation pattern can appear. Our results derived from chromatin immunoprecipitation analysis revealed that the H3K9 acetylation pattern of euchromatic regions changed in the loss of dSAGA activity. It is possible that the hypoacetylated chromatin structure weakens the binding affinity of regulatory factors - which can be either activators or repressors - and hence the transcription of genes under their control could be changed according to the loss of the regulatory function. Similar hypothesis can partially explain the fact that down- and upregulated genes could be identified in the loss of dSAGA specific acetylation. Moreover, this dynamic global acetylation pattern may also contribute to the suitable kinetics of transcription regulation. This concept can be proven by data indicating altered kinetics of the activation of the in vivo model genes (Eip74EF and Eip75B) by the loss of dSAGA specific H3K9 acetylation. Therefore, in the loss of the dSAGA specific global H3K9 acetylation pattern activation of specific genes can not be performed in proper time, which can cause the shuffling of coordinated gene expression pattern characteristic for the cell. 


\section{Függelék}

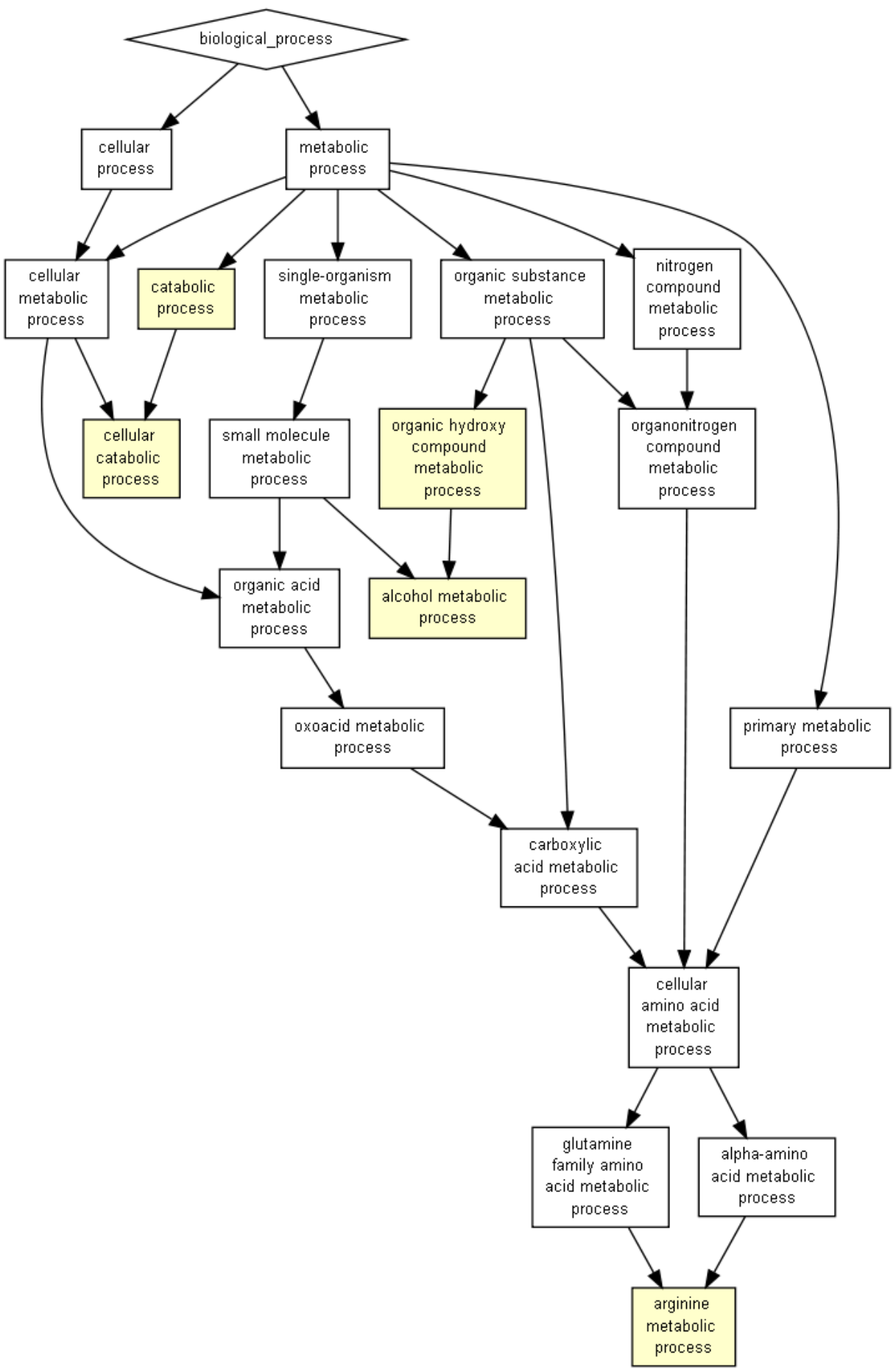

F1. ábra: Az ábrán a dAda2b mutánsban $\mathrm{SpEv}$ állapotban csökkent expressziót mutató gének között azonosítható, szignifikánsan felülreprezentált biológiai folyamatoknak megfelelö génontológiai csoportok láthatóak.

A fehér színnel jelölt kategóriákba eső gének feldúsulásának szignifikancia szintje $\mathrm{P}>10^{-3}$; a citromsárgára színezett kategóriákba esőké $10^{-3}>\mathrm{P}>10^{-5}$. 


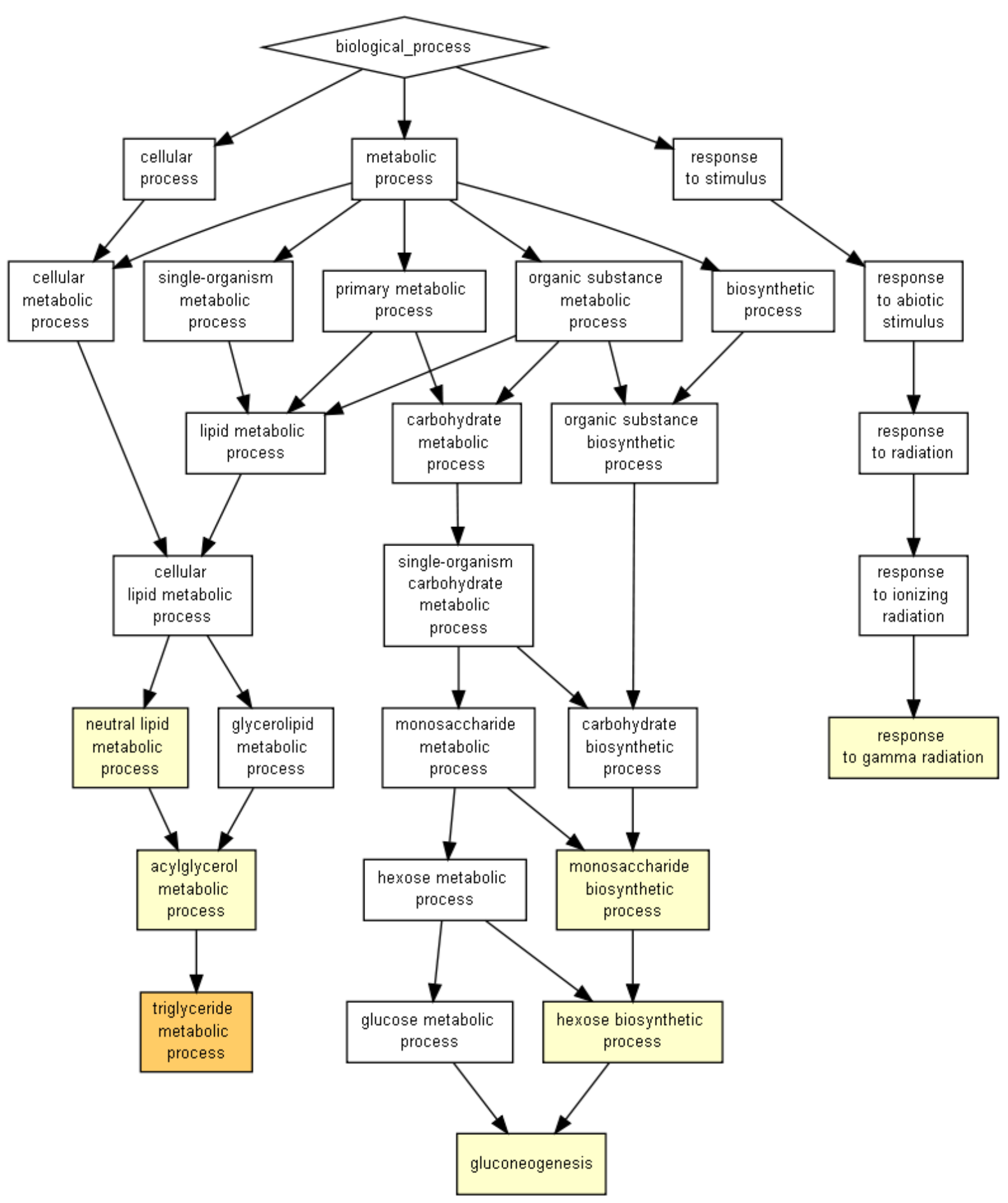

F2. ábra: Az ábrán a dAda2b mutánsban korai báb állapotban csökkent expressziót mutató gének között azonosítható, szignifikánsan felülreprezentált biológiai folyamatoknak megfelelő génontológiai csoportok láthatóak.

A fehér színnel jelölt kategóriákba eső gének feldúsulásának szignifikancia szintje $\mathrm{P}>10^{-3}$; a citromsárgára színezett kategóriákba esőké $10^{-3}>\mathrm{P}>10^{-5}$; a narancssárgákba eső géneké pedig $10^{-5}>\mathrm{P}>10^{-7}$. 


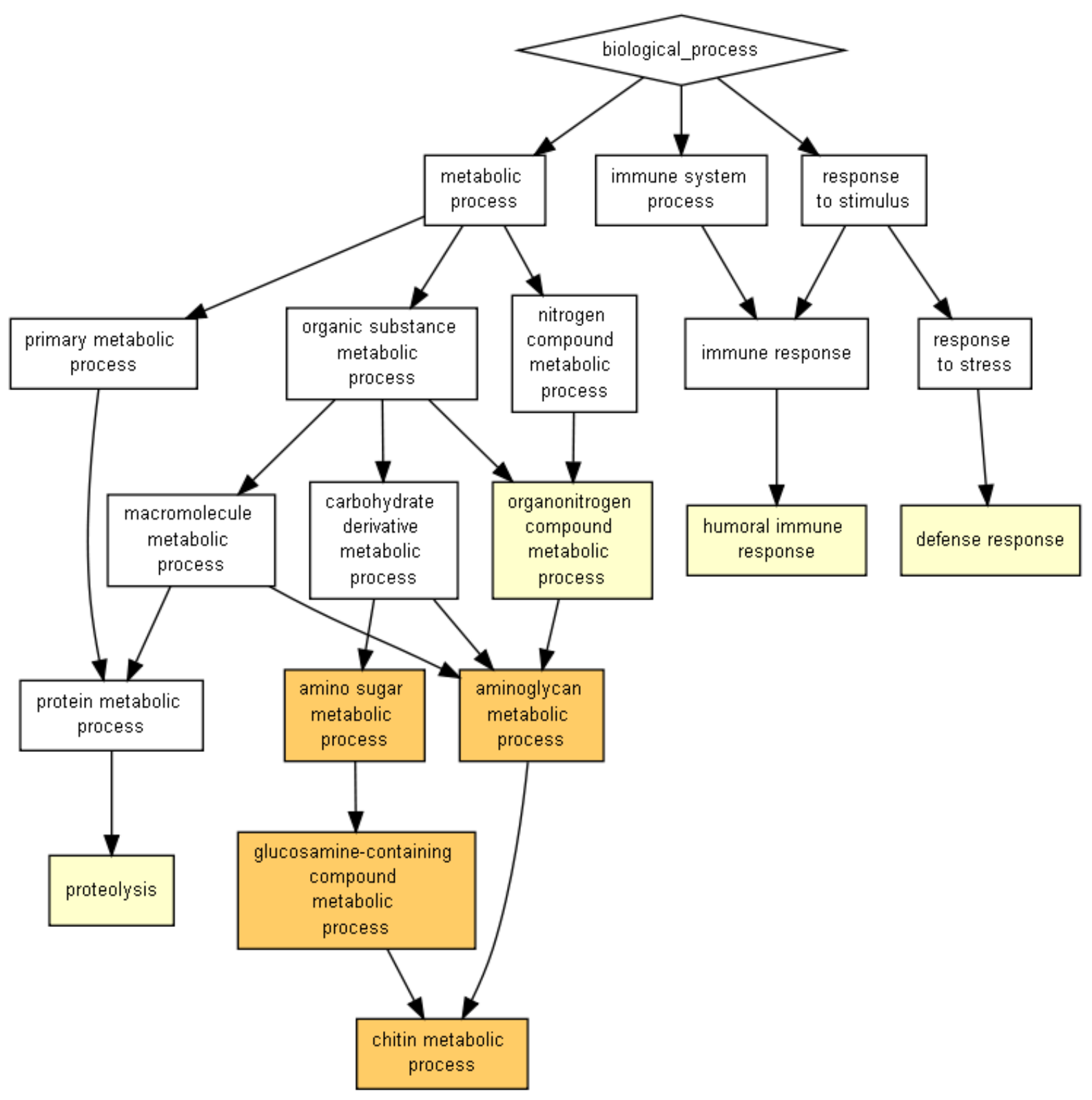

F3. ábra: $A z$ ábrán a dAda2b mutánsban $\operatorname{SpEv}$ állapotban emelkedett expressziót mutató gének között azonosítható, szignifikánsan felülreprezentált biológiai folyamatoknak megfelelő génontológiai csoportok láthatóak.

A fehér színnel jelölt kategóriákba eső gének feldúsulásának szignifikancia szintje $\mathrm{P}>10^{-3}$; a citromsárgára színezett kategóriákba esőké $10^{-3}>\mathrm{P}>10^{-5}$; a narancssárgákba eső géneké pedig $10^{-5}>\mathrm{P}>10^{-7}$. 


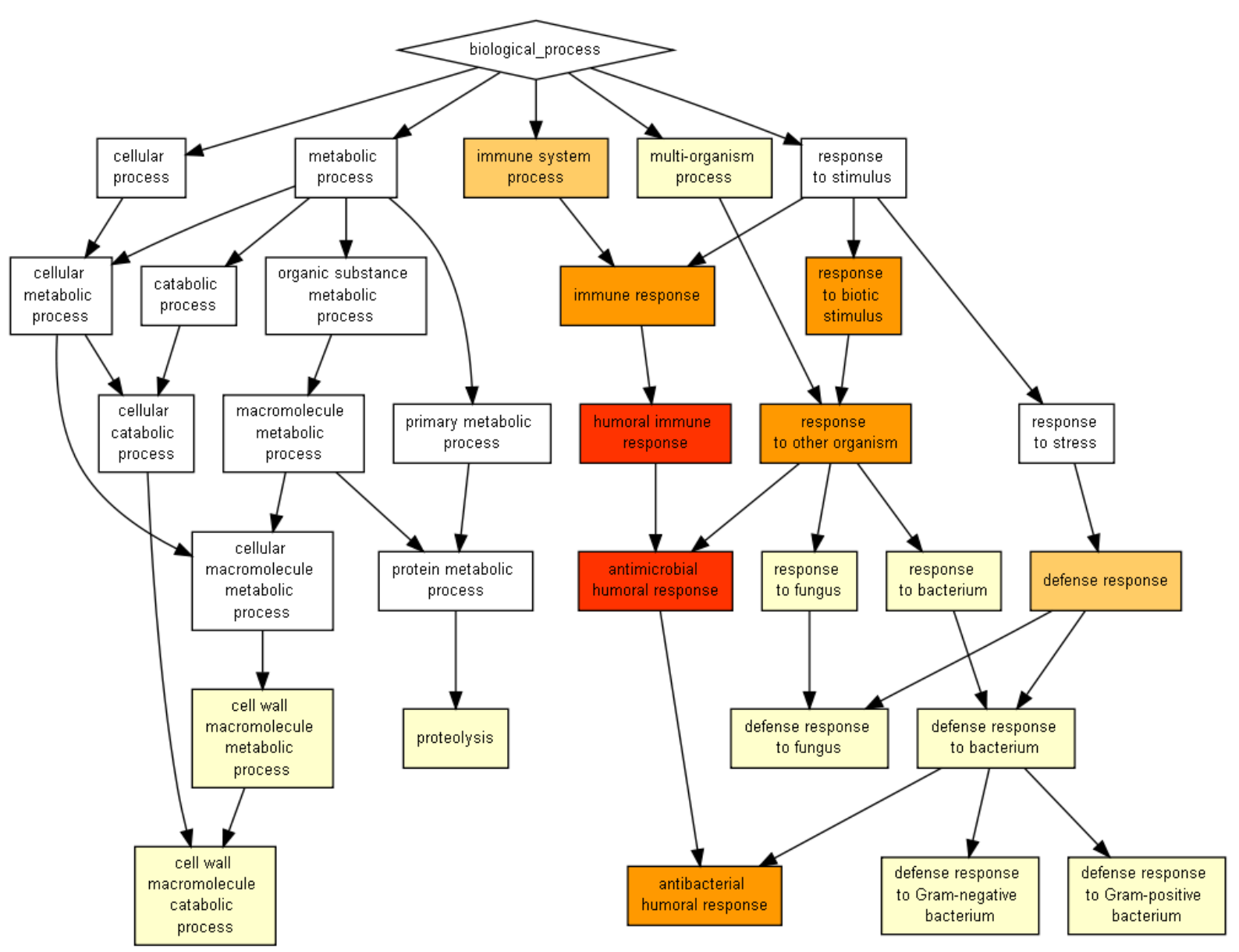

F4. ábra: Az ábrán a dAda2b mutánsban korai báb állapotban emelkedett expressziót mutató gének között azonosítható, szignifikánsan felülreprezentált biológiai folyamatoknak megfelelő génontológiai csoportok láthatóak.

A fehér színnel jelölt kategóriákba eső gének feldúsulásának szignifikancia szintje $\mathrm{P}>10^{-3}$; a citromsárgára színezett kategóriákba esőké $10^{-3}>\mathrm{P}>10^{-5}$; a narancssárgákba esőké $10^{-5}>\mathrm{P}>10^{-}$ 7; a pirosba tartozóké $10^{-7}>\mathrm{P}>10^{-9}$. 